
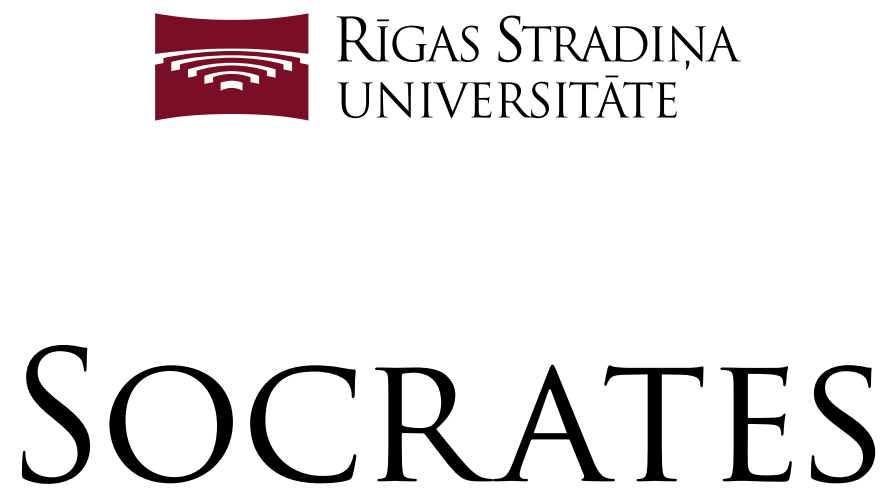

2018, NR. 2 (11)

Rīgas Stradiña universitātes

Juridiskās fakultātes

elektroniskais juridisko

zinātnisko rakstu žurnāls

Rīga Stradiṇš University

Faculty of Law

Electronic Scientific

Journal of Law

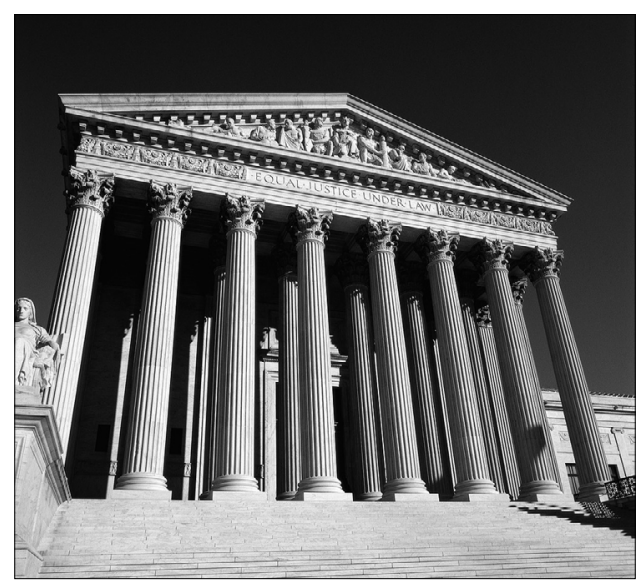

RĪGA • 2018 • RSU 
Socrates: Rīgas Stradiṇa universitātes Juridiskās fakultātes elektroniskais juridisko zinātnisko rakstu žurnāls = Rīga Stradin̄š University Faculty of Law Electronic Scientific Journal of Law. Rìga: RSU, 2018., Nr. 2 (11). 117 lpp.

\section{Redkolēgija / Editorial Board}

Jānis Gardovskis (vadītājs) - Dr. habil. med. profesors, Rīgas Stradiṇa universitāte, Latvija Iveta Ozolanta - Dr. habil. med. profesore, Rīgas Stradiña universitāte, Latvija Andrejs Vilks (atb. zin. redaktors) - Dr. iur. profesors, Rīgas Stradiṇa universitāte, Latvija

Vladimirs Eminovs - Dr. habil. iur. profesors, Maskavas Valsts juridiskā universitāte, Krievija Osvalds Joksts - Dr. habil. iur. profesors, Rīgas Stradiña universitāte, Latvija Viktors Justickis - Dr. habil. iur. profesors, Viḷnas Mỉkola Romera universitāte, Lietuva Sandra Kaija - Dr. iur. profesore, Rīgas Stradiņa universitāte, Latvija Valters Kego (Walter Kego) - Zviedrijas Drošỉbas un politikas attīstības institūts, Zviedrija Ando Leps - Dr. habil. iur. profesors, Tallinas universitāte Nord, Igaunija

Jaceks Zeḷinskis (Jacek Zielinski) - Dr. habil.sc. pol. profesors, Siedlces Dabas un humanitāro zinātñu universitāte, Polija

Alvīds Šakočs (Alvydas Šakočius) - Dr. iur. profesors, Lietuvas Militārā akadēmija, Lietuva

Vitolds Zahars - Dr. iur. profesors, Daugavpils Universitāte, Latvija

Natālija Gutorova (Nataliya O. Gutorova) - Dr. iur. profesore, Poltavas Tiesību institūts, Jaroslava Gudrā Nacionālā juridiskā universitāte, Ukraina

Vitālijs Paškovs (Vitaliy M. Paschkov) - Dr. iur. profesors, Poltavas Tiesību institūts, Jaroslava Gudrā Nacionālā juridiskā universitāte, Ukraina

Redakcijas padome / Editorial Council (Rīgas Stradiṇa universitāte)

Jānis Baumanis - Dr. iur. vadošais pētnieks

Jānis Grasis - Dr. iur. asoc. profesors

Osvalds Joksts - Dr. habil. iur. profesors

Aldis Lieljuksis - Dr. iur. asoc. profesors

Sandra Kaija - Dr. iur. profesore

Uldis Kinis - Dr. iur. asoc. profesors

Andrejs Vilks - Dr. iur. profesors

Tenis Nigulis - Izdevniecības un poligrāfijas nodaḷas vadītājs

Visi žurnāāa ievietotie raksti ir recenzēti. / All journal articles are reviewed.

Citējot atsauce uz izdevumu ir obligāta. / Upon citing the journal article, reference to the journal is mandatory.

Autoru viedoklis var nesaskanēt ar redkolēgijas viedokli. / Opinion of authors may not coincide with the editorial views.

Par faktu pareizibu atbild autori. / The authors are held responsible for the truthfulness of the facts.

Redaktori / Editors: Ināra Mikažāne (latviešu val.), Jānis Zeimanis (angḷu val.)

Korektore / Corrector: Indra Orleja (latviešu val.)

Maketētāja / Layout: Ilze Stikāne

RSU IPD Nr. 18-218

(c) Rīgas Stradina universitāte, 2018

Dzirciema iela 16, Rīga, LV-1007

ISSN 2256-0548 


\section{Saturs / Contents}

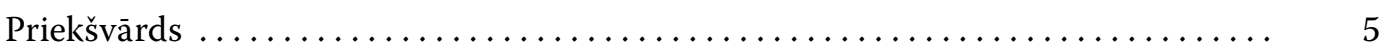

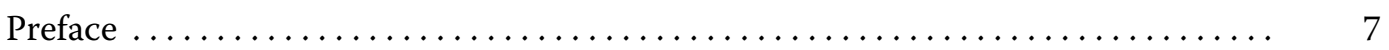

Vitaliy M. Pashkov. Immunoprophylaxis in Healthcare:

Human Rights Context . .......................... 9

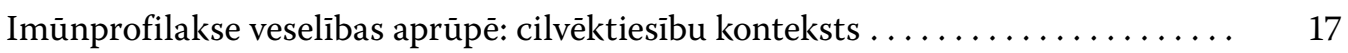

Artur Kokoszkiewicz. Tasks of the State and Role of Social Law in

the Field of Social Welfare . . . . . . . . . . . . . . . . . . . . . . 19

Valsts uzdevumi un sociālo tiesību nozīme sociālās labklājības jomā . . . . . . . 25

Rihards Ērdmanis. Tiesības uz izglītību: izglītības skaidrojums

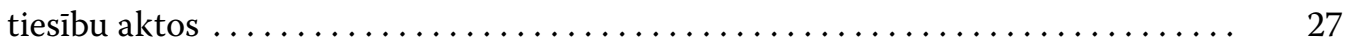

Right to Education; the Term Education and Its Legal Aspect $\ldots \ldots \ldots \ldots \ldots . .$.

Rolands Kikors. Latvijas Republikas privāttiesību tiesu praksē laiks

pāršḳirt lappusi analogijas jēdziena un satura izpratnes attīstībā $\ldots \ldots \ldots \ldots$. . 37

It is Time to Turn Over a New Page in Evolution of

Understanding the Concept and Matter of Analogy in Private Law

Court Practice in the Republic of Latvia $\ldots \ldots \ldots \ldots \ldots \ldots \ldots \ldots \ldots \ldots$

Zane Rinmane. Globalizācijas ietekme uz līgumsoda piemērošanu . . . . . . . 50

Impact of Globalisation on the Application of

the Contractual Penalty ........................... 63

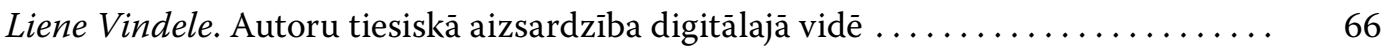

Legal Protection of Authors' Rights in the Digital

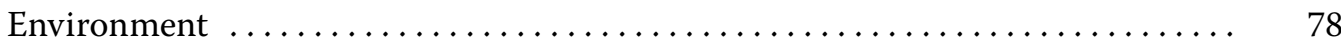

Jeḷena Alfejeva. Sporta jēdziens un tā attiecināšana uz prāta spēlēm . . . . . . . 81

Definition of "Sport" and Its Extension to Mind Games . . . . . . . . . . . 87

Linda Reisa. Zvērināta advokāta orderis kā tiesību elements . . . . . . . . . . 90

Sworn Advocate's Retainer as Legal Element .................... 98 
Nataliya O. Gutorova. White-Collar Crime: Ukrainian Experience of Searching for Optimal Model of Criminal Liability

Balto apkaklī̌su noziedzība: Ukrainas pieredze, meklējot

kriminālatbildības optimālo modeli

Autoru alfabētiskais rādītājs / Alphabetic List of Authors 


\section{Priekšvārds}

Socrates 11. izdevumā pārsvarā ir ietverti raksti, kuri ir veltiti civiltiesisko problēmu lokam. Tajos analizēti sociālo un medicīnas tiesību daudzveidīgie aspekti.

Profesors Vitālijs Paškovs (Vitaliy M. Pashkov) ir pievērsies imūnprofilakses jautājumiem veselības aprūpēs jomā, skatot to cilvēktiesību kontekstā. Autors detalizēti analizē cilvēka tiesības atteikties no medicīniskiem pakalpojumiem, tostarp vakcinācijas, kā arī cilvēku tiesības uz veselības aprūpi saistībā ar infekcijas slimību profilaksi. Tēma un raksta saturs ir aktuāls un saistošs.

Polijas tiesību zinātnieks Arturs Kokoškevičs (Artur Kokoszkiewicz) savā publikācijā apskata valsts uzdevumus sociālajā jomā un analizē sociālo tiesību lomu sociālās aizsardzības veidošanā. Lasītāji gūs informāciju par funkcijām, kuras sociālie tiesību akti ir ḷāvuši izpildīt agrāk un mūsdienās. Autors piedāvā dažādus sociālās labklājības modeḷus, ieskicējot sociālo tiesību lomu šajā jomā.

Jaunais tiesībpētnieks Rihards Ērdmanis ir padziḷināti analizējis problēmu, kas saistīta ar tiesībām uz izglītību, un izglìtības skaidrojumu tiesību aktos. Nevar nepiekrist R. Ērdmaņa kungam, ka "izglītība ir labums, kas veicina arì citu sabiedrības labumu attīstību, piemēram, augstvērtīgu un pārdomātu politisko lēmumu pieṇemšanu”, kuru, iespējams, atsevišḳos gadījumos mūsu globālajā vidē tomēr trūkst.

Rolands Kikors savā rakstā analizē Latvijas Republikas tiesu praksi, tostarp analogijas kā juridiskās metodes piemērošanu privāttiesībās. Jāpiekrīt autora secinājumam, ka pareiza analog̣ijas piemērošana vairs nevar tikt saistīta tikai ar sausu analog̣ijas jēdziena iegaumēšanu un piemērošanu noteiktās situācijās. Autora raksta nosaukums ir visai ambiciozs - "Latvijas Republikas privāttiesību tiesu praksē laiks pāršḳirt lappusi analogijas jēdziena un satura izpratnes attīstībā". Vai judikatūras attīstîba ir saistāma ar valsts vēsturisko attīstību? Iespējams, ka tā būtu jābūt.

Zane Rinmane ir pievērsusies globalizācijas faktoru ietekmes analīzei līgumsodu piemērošanas procesos. Raksta noslēgumā ir formulēts secinājums, ka "līgumsoda evolūciju Latvijā ir ietekmējusi globalizācija, kas saistīta ar geogrāfisko robežu izzušanu, tādējādi saasinot jautājumus, tostarp par saistību izpildi un līgumsoda piemērošanu". Minētajam nevar nepiekrist.

RSU tiesību zinātṇu doktorante Liene Vindele analizē pašreiz īpaši aktuālu un nozìmīgu problēmu - autoru tiesisko aizsardzību digitālajā vidē. Digitālās vides attīstība ir l̦āvusi konstatēt arī autortiesību regulējuma nepilnības, kuru novēršanai ir nozīmīga loma ne tikai Latvijā, bet arī visā pasaulē. Digitalizācijas laikmetā patērētājam ir iespējams salīdzinoši vieglāk piekḷūt nelegālam saturam digitālajā vidē nekā atrast legālu avotu. Var 
pievienoties autores viedoklim, ka ir būtiski izglītot sabiedrību par autortiesībām, nevis tikai ieviest soda sankcijas, tāpēc izglītojoši pasākumi var veicināt sabiedrības izpratni par autortiesību sistēmu.

Tiesību doktore Jel̦ena Alfejeva skata jaunu tēmu - sporta jēdziena izpratni un tā attiecināšanu uz prāta spēlēm. Autore secina, ka sports ir visu veidu individuālas vai organizētas aktivitātes fiziskās un garīgās veselības saglabāšanai un uzlabošanai un saistîts ar panākumu gūšanu sporta sacensībās. J. Alfejeva uzsver, ka minētā jēdziena izpratne nav viennozìmīga.

Lasītājiem būs interesants Lindas Reisas raksts par zvērināta advokāta orderi kā tiesību elementu. Juridiskajā vidē nav noslēpums, ka notiek diskusijas par atteikšanos no ordera kā advokāta lietvedības dokumenta. Interesants ir autores piedāvājums orderi aizstāt ar elektronisku iespēju personām un iestādēm pārliecināties par zvērināta advokāta tiesībām pildīt likumā noteiktos pienākumus un uzṇemties tiesības.

Poltavas Tiesību institūta profesore Natālija Gutorova (Nataliya O. Gutorova) analizē sociāli visai sensitīvu problēmu - t. s. balto apkaklī̌su noziedzību Ukrainā, izzinot iespējamo kriminālatbildības optimālo modeli. Ar baltajām apkaklìtēm saistìtais ēnu ekonomikas līmenis Ukrainā ir visai augsts $-45,96 \%$ no IKP un ir tuvs atbilstošam Nigērijas rādītājam. Autores pieeja ir attiecināma uz diviem aspektiem: pirmkārt, novērst darbību pārlieku kriminalizāciju; otrkārt, efektīvi sodīt baltās apkaklìtes par noziegumiem.

Rakstu tematika ir daudzveidīga un atspogulo daudzpusīgus tiesību zinātnes teorētiskos un praktiskos aspektus, kas varētu saistìt plašu interesentu loku.

ANDREJS VilKs, Dr. iur., RSU Juridiskās fakultātes profesors 


\section{Preface}

Socrates $11^{\text {th }}$ edition primarily includes articles that deal with the issues of civil liability. They analyse the diverse characteristics of social and medicine laws.

Professor Vitaliy M. Pashkov has addressed the topic of immunoprophylaxis in health care via the context of human rights. The author analyses every human's rights to refuse any medical service, including immunisation, as well as the rights of a person to receive health care in connection with the prevention of infectious diseases. The raised issue deems topical and binding.

The Polish law scientist Arturs Kokoszkiewicz in his publication reviews a state's tasks in social sphere and analyses the role of social law in the formation of social protection. Readers will be exposed to functions executed earlier and now as allowed by social legislation. The author offers various social welfare models sketching the role of social law in the field.

The new law student Rihards Ërdmanis has conducted an in-depth analysis on the right to education and the legal aspects of the term education. It is hard to argue Mr. Ërdmanis" claim that "education is the benefit which fosters the development of other social benefits; for example, high-value and sound political decision-making", which we, in some cases, in our global environment probably lack.

Rolands Kikors in his article analyses the Law Court practice in the Republic of Latvia, including application of analogy as a judicial method in private law court. One would agree with the conclusion provided by the author that appropriate analogy application is not any more mere memorisation and implementation of it in particular situations. The title of the article is quite ambitious - "It is Time to Turn Over a New Page in Evolution of Understanding the Concept and Matter of Analogy in Private Law Court Practice in the Republic of Latvia". Is the development of case law connected with the historical development of a country? Probably, this is what it should be like.

Zane Rinmane has addressed the impact of globalisation on the application of the contractual penalty. The conclusion of the article reads "evolution of contractual penalty in Latvia has been affected by globalisation, which is directly connected with the disappearance of physical borders, thus exacerbating questions on fulfilment of obligations and application of contractual penalties". It is difficult to disagree with the stated above.

RSU doctorate in law Liene Vindele analyses a currently very topical and significant problem - legal protection of authors' rights in the digital environment. Development of the digital environment has allowed for scrutiny of copyright deficiencies, the elimination of which is significant not only in the context of Latvia, but also world-wide. The digital era has provided much easier opportunities for a consumer to access the illegal content 
in the digital environment than locate the legal one. One can agree with the viewpoint of the author that it is important to educate society on copyright issues, not just establish a penalty system; therefore, educational measures may promote societal understanding on the role of copyright issues.

Doctor of law Jelena Alfejeva addresses a new topic - understanding the definition of "sport" and its extension to mind games. The author concludes that sport can be understood as diverse individual and group activities with the aim to maintain and improve one's physical and mental health, and it also aims to gain success in sport competitions. J. Alfejeva stresses that the term is rather ambiguous.

Readers may find appealing Linda Reisas' article on sworn advocate's retainer as a legal element. It is not a secret that in the legal environment discussions among professionals take place about the abandonment of the retainer as a lawyer's recordkeeping document. The author proposes an interesting solution to replace the retainer with an electronic opportunity for people and legal institutions to verify the rights of a sworn advocate to perform statutory duties and take the right.

The Professor of the Law Institute of Poltava Nataliya O. Gutorova analyses quite a sensitive issue for society - white-collar crime in Ukraine, defining the optimally probable model of criminal liability. The white-collar shadow economy level is rather high in Ukraine $-45.96 \%$ of the GDP and correlates with the respective data of Nigeria. The author's approach can be related to two aspects: first, prevent excessive criminalization activities; second, effectively punish white-collar criminals.

The subject matter of the articles is diverse, and it reflects comprehensive theoretical and practical aspects of law, which could appeal to a wide range of readers.

ANDREJS VilKs,

Professor, Dean of the Faculty of Law at Rīga Stradiñ̌s University 


\title{
Immunoprophylaxis in Healthcare: Human Rights Context
}

\author{
Dr. iur. Vitaliy M. Pashkov \\ Poltava Law Institute of Yaroslav Mudry National Law University, Ukraine \\ v.pashkov26.06@ukr.net
}

\begin{abstract}
Author has addressed the topic of immunoprophylaxis in health care via the context of human rights. The author analyses every human's rights to refuse any medical service, including immunisation, as well as the rights of a person to receive health care in connection with the prevention of infectious diseases. The raised issue deems topical and binding.
\end{abstract}

Keywords: immunoprophylaxis, healthcare, principle of proportionality.

\section{Introduction}

In Ukraine as well as in most member states of the European Union, any medical service, including diagnostic or preventive ones, requires a patient's informed voluntary consent and, as a consequence, it appears that a person has the right to refuse immunoprophylaxis by means of vaccination. In particular, Art. 5 of the Convention on Human Rights and Biomedicine determines that

"an intervention in the health field may only be carried out after the person concerned has given free and informed consent to it. This person shall beforehand be given appropriate information as to the purpose and nature of the intervention as well as on its consequences and risks. The person concerned may freely withdraw consent at any time.” [2]

Art. 6 proclaims that where, according to law, a minor does not have the capacity to consent to an intervention, the intervention may only be carried out with the authorisation of his or her representative or an authority or a person or body provided for by the law [2]. At first sight, a person allegedly has the right to take charge of their private life refusing medical intervention or preventive measures for whatever reason. However, analysis of key international documents, including such a source of law as judgments 
of the European Court of Human Rights (ECtHR), leads to the conclusion that such an interpretation is imperfect. This is because lawyers look into such type of medical services as immunoprophylaxis mainly from the perspective of private law dimension of a person's other rights, in particular, the right to education, the right to childhood, the right to work, as well as the freedom of religion and conscience. Thus, they disregard not only the content of international legal instruments on protection of human rights and fundamental freedoms, but also practice of the European Court of Human Rights concerning essence of the legal nature of limiting patients' rights as to consent or refusal of medical intervention to eliminate threat of harm to the third party's health. Meanwhile, the third party's rights should also be taken into account in the context of what is stated in Art. 2 of the Universal Declaration of Human Rights which provides that everyone is entitled to all the rights and freedoms set forth in this Declaration [21]. However, this is where the problem arises with application of the principle of proportionality which allows the judicial bodies to reason their judgments consistently and in detail [1].

Scientific works by leading experts in medical and pharmaceutical law as well as current legislation have been used in the research.

The issues of protection of patients' rights and pharmaceutical activities have been studied by the following scholars, namely, V. Tatsiy [19], N. Gutorova [10], A. Harkusha [11], Y. Hrekov [12], A. Olefir [15], A. Kotvitska [13], A. Soloviov [16], L. Udovyka [17] and other well-known experts [14]; however, insufficient attention has been paid to the issues of judicial consideration of cases involving protection of patients' rights, since only quite recently medical and pharmaceutical law as a whole has become the subject of scientific research in the domestic legal science.

Methodology of this research is based on organic combination of general scientific and special legal methods of studies, among which there are principles of objectivity, some techniques of a logical method, systemic and structural-functional methods, a method of legal simulation. Exactly, systematic method is applied to perform system analysis of the current legislation which regulates judicial consideration of cases involving protection of patients' rights. A structural-functional method allows revealing the main constituents of judicial considerations of the relevant category. A method of legal simulation is applied to formulate proposals for improving the existing legislation and practice of judicial consideration of cases involving protection of patients' rights.

Thus, assessment of third party's right to health and other people's rights consisting in provision of such rights and freedoms as the right to education, childhood and religion should be considered through the principle of proportionality or balancing.

\section{Results and Discussion}

Proportionality is the key concept to understanding how law operates. This comes from Art. 8 of the European Convention on Human Rights and Fundamental Freedoms (ECHR). The Convention is protected by the European Court of Human Rights, which was established in 1959 [1]. The principle of proportionality is to be acknowledged as one 
of the plentiful "safety devices" able to assist in protecting a particular person against lawlessness or unjustified abuse of the power by public servants authorised to apply procedural coercive measures [9]. Balancing is in vogue in Europe, Canada, India, South Africa, and elsewhere; courts invoke balancing as the proper method of human rights adjudication. The European Court of Human Rights, by its own admission, routinely balances human rights against each other and against conflicting public interests and, in many countries, proportionality has been elevated, implicitly, to a basic constitutional principle [20]. At the same time, judgments of the ECtHR are consistent with both basic provisions of the European Convention for the Protection of Human Rights and Fundamental Freedoms and constitutional principles of European countries.

One of the current problems in ensuring the right to health is an ambiguous attitude towards the constituent part of this right, namely, immunoprophylaxis on the part of the public.

Meanwhile, most medical experts claim that immunoprophylaxis has been demonstrated to be a highly efficacious strategy in the primary prevention of disease, and most European countries impose mandatory vaccination according to the vaccination schedule. In addition, individuals and communities understand the value of vaccines and demand immunisation as both their right and responsibility [6].

Thus, in pursuance of urgent vaccination regulations dated June 7, 2017, in the Italian Republic, according to the National Immunisation Schedule, twelve vaccine types for children under the age of sixteen are mandatory and free of charge in order to ensure public health protection and preservation of epidemiological safety, prevention and vaccination coverage, as well as in compliance with European and international commitments.

In case of non-compliance with the vaccination obligation, parents incur a monetary liability, and local public health authorities must report failure to comply with the vaccination obligation to the prosecutor [3].

In its turn, Section 20 of the Act on the Reform of the Communicable Diseases Law (Communicable Diseases Law Reform Act) establishes that a Standing Vaccination Commission shall be established at the Robert Koch Institute. The Commission adopts Rules of Procedure that are subject to the consent of the Federal Ministry for Health. The Commission issues recommendations on the conduct of vaccinations and other measures for specific prophylaxis of communicable diseases and develops criteria for the distinction between a normal post-vaccinal reaction and a health impairment the degree of which exceeds that of a normal post-vaccinal reaction. Besides, supreme health authorities of the Laender can determine that health offices conduct vaccinations or other measures of specific prophylaxis against certain communicable diseases free of charge [6]. Or, for example, in the USA, if a child is denied school attendance because she is not immunised and the parent does not qualify for a lawful exemption, the parent can be prosecuted for failing to meet the requirements of compulsory education for her state, but cannot claim the fact that the school denied her child entrance because she was unimmunised as a defense [18]. According to Polish law, part of preventive vaccinations is obligatory and 
another part is recommended. Vaccinations are mandatory for everyone (both insured persons, as well as uninsured) and funded from public funds. Funding for recommended vaccination is varied. In the case of their implementation by the primary care provider selected by the patient, the patient covers only the cost of the vaccine preparation and the service provider bears the costs of qualification tests and implementation of vaccination. If a patient decides for vaccinations at a commercial point of vaccination, they cover their costs in full [8].

Thus, in most developed countries, there is legal and regulatory leverage over their citizens concerning enforcement of the right to health by means of immunoprophylaxis, which is generally confirmed by the European Vaccine Action Plan 2015-2020 (EVAP). The WHO Regional Office for Europe. Background Plan affirms that immunisation has brought about a remarkable reduction in child mortality in the WHO European Region over the past few decades. Today, nine of every ten children in the Region receive at least a basic set of vaccinations during infancy, and as a result lead healthier, more productive lives [22].

Despite sufficient legal framework and other levers of influence concerning evasion of immunoprophylaxis, in some cases domestic courts generally misinterpret international acts referring to them in terms of enforcing a third party's right to health or another person's rights and freedoms.

To clarify the nature of these deficiencies, first it is necessary to analyse the practice of the European Court of Human Rights (ECtHR), especially since its judgment is a source of law for our country. But here again, proportionality is one of the main principles scrutinising actions adopted by national authorities which restricts rights under the European Convention for the Protection of Human Rights and Fundamental Freedoms of November 4, 1950 [5].

As far as vaccination is regarded, there are numerous references to the same judgments of the ECtHR, for instance, they often refer to the case of Jehovah's Witnesses of Moscow and Others vs. Russia (Application No. 302/02), Strasbourg, June 10, 2010. Nevertheless, even commenting on this case, most lawyers focus only on international acts used by the Court, but not on the principles and methods of evaluating materials as well as conclusions. In other words, in this case, when addressing the issues of vaccination, the decision-making principles and, in some cases, specific conclusions of the very nature of the vaccination itself are important for lawyers. Some conclusions are also important, in particular, that in paragraph 136, where it is stated that "it was emphasised that free choice and self-determination were themselves fundamental constituents of life and that, absent of any indication of the need to protect third parties - for example, mandatory vaccination during an epidemic, the State must abstain from interfering with the individual freedom of choice in the sphere of healthcare, for such interference can only lessen and not enhance the value of life." However, preliminarily it is necessary to use paragraph 85, which refers to the precedent heard by the Ontario Supreme Court in Canada: 


\begin{abstract}
"The state undoubtedly has a strong interest in protecting and preserving the lives and health of its citizens. There clearly are circumstances where this interest may override the individual's right to self-determination. For example, the state may, in certain cases, require that citizens submit to medical procedures in order to eliminate a health threat to the community." [4]
\end{abstract}

In Ukraine cases of mandatory vaccination are heard by courts in both civil and administrative proceedings. Their judgments are rather controversial and often not properly reasoned. However, analysis of these cases makes it possible to classify patients who refuse to be vaccinated legally for several reasons, in particular: 1) for health reasons; 2) according to religious beliefs; 3) because of neglecting their duties as parents which leads to serious illnesses entailing significant harm to a child's health; 4) due to distrust of the competence of medical personnel.

Separate group of patients are persons that for distinct reasons refuse to be vaccinated in a non-legal way by obtaining a fake certificate of vaccinations issued by a healthcare practitioner.

If we consider vaccination as one of health services, the right to this type of service is to be considered in the context of consent to medical intervention. In other words, a patient's informed consent is required to use diagnostic, preventive and treatment methods.

An example of contradictory ideas as to the principles of law can be observed within judgments in various but similar cases of one of the courts in Volyn region.

Volyn District Administrative Court in the case No. 2a-18037/09/0370 of July 2, 2009 , refusing to satisfy the claim for the invalidation of the application for removal from attending a child at a pre-school educational institution, substantiated his decision by the fact that Part 2 of Art. 15 of the Law of Ukraine "On Protection of the Population against Infectious Diseases", which explicitly stipulates that children who have not received preventive vaccinations according to the schedule of vaccinations, visits to children's facilities are not allowed. Furthermore, since in pursuance of Part 2 of Art. 11 of the Law of Ukraine "On Pre-School Education", a pre-school institution shall create safe and harmless conditions for children's development, education and training, mode of operation, conditions for physical development and health promotion in accordance with sanitary and hygienic requirements and ensure their compliance, therefore, attending pre-school educational institutions by children who have not undergone mandatory preventive vaccinations will violate the rights of other children (who have undergone such vaccinations) to safe and harmless conditions of development, education and training in accordance with sanitary and hygienic requirements.

Two other cases, No. 2a-6501/09/0370 (the ruling dated March 16, 2009) and No. 2a/0370/2586/11 (the ruling dated October 12, 2011) were heard by Volyn District Administrative Court by a different panel of judges. The main feature there is that they were both tried by the same panel of judges and they both resulted in opposite judgments. 
In the first case (the ruling dated March 16, 2009) on behalf of other persons, the prosecutor of the city of Lutsk appealed to the sanitary epidemiological service to declare illegal and cancel the application for removal from attending the secondary school of I-III steps of children not received vaccinations. The claims were motivated by virtue of Art. 53 of the Constitution of Ukraine, according to which everyone has the right to education and Art. 3 of the Law of Ukraine "On Education" which stipulates that citizens of Ukraine shall have the right to free education in all public educational institutions regardless of their gender, race, nationality, social and economic status, type and nature of their activities, world views, belonging to parties, attitude towards religion, religious conscience, state of health, place of residence and other circumstances. At the same time, the court did not take into consideration the reference of the Sanitary Epidemiological Service to the fact that failure to observe requirements of the Law of Ukraine "On Protection of Population against Infectious Diseases" which recognises vaccinations for prevention of tuberculosis to be mandatory may lead to violation of other people's rights, in this case, children studying with the plaintiffs' children at the secondary school of I-III degrees, since as it was stated in the court session, all the abovementioned children studying at this school had undergone a medical examination and were declared healthy, which was also not objected by the defendant's representatives.

In this case, there is a misconception as even if the court used the principle of proportionality it was mistaken in such situation. Due to misunderstanding of the principle of correspondence, the court ignored the algorithm of conducting the proportionality test.

In the other case No. 2a/0370/2586/11 (the ruling dated October 12, 2011), the same panel of judges heard a complaint filed against the Medical Advisory Commission at the children's clinic of Kovel City Medical Association of the Public Health Department of Volyn Regional State Administration on recognising actions regarding refusal to issue a permit to attend a pre-school educational institution. The plaintiff motivated his claims by the child's right to education which is provided for by the Constitution of Ukraine whose rules are rules of direct effect, the ruling of the Constitutional Court of Ukraine which contains an official interpretation of access to education as a constitutional guarantee of the right to education on the principles of equality, and therefore, restriction of this right is possible only in conditions of emergency or martial law, otherwise, Article 15 of the Law of Ukraine "On Protection of Population against Infectious Diseases" as to prohibition of attending pre-school educational institutions by children who have not undergone preventive vaccinations contradicts the Constitution of Ukraine.

Denying the claim in accordance with parts 1, 6, 7 of Art. 12, part 2 of Art. 15 and Art. 41 of the Law of Ukraine "On Protection of the Population against Infectious Diseases", the court noted that preventive vaccinations against diphtheria, pertussis, measles, poliomyelitis, tetanus, tuberculosis are mandatory and included in an immunisation schedule, and children who have not undergone preventive vaccinations according to the immunisation schedule cannot attend children's institutions. Persons responsible for violating the legislation on protection against infectious diseases incur a liability in accordance with the laws of Ukraine. 
In view of the content of the mentioned rule, the court considers the plaintiff's reference to discrimination, which is in denied access to education or any violations of the child's right to education, to be not true and thus the person's claims are unacceptable.

Even though the court pronounced a proportional judgment, unfortunately, it still did not comply with proportionality test. Use of the principle of legality by the court of this instance was more likely to be appropriate, although it would have been appropriate for a higher court to use the principle of the rule of law. The problems of legal linguistics in the context of the Convention for the Protection of Human Rights and Fundamental Freedoms (ECHR) of November 4, 1950, which enunciates the principle of the rule of law, were discussed by the Parliamentary Assembly of the Council of Europe (see: Resolution No. 1594 (2007)). The Parliamentary Assembly drew attention to the fact that in some recent democracies in Eastern Europe, the main trends in legal thinking foster an understanding of the "rule of law" as "supremacy of statute law", i.e. primacy of law.

In another case, No. 2-a/337/3087/17 (the ruling dated October 09, 2017), the court heard a person's complaint filed against the Territorial Education Department of Khortytsia district of the Education and Science Department of Zaporizhia City Council on recognising actions as illegal regarding denied enrollment of a child in a pre-school educational institution, which is a kindergarten. The plaintiff refers to the fact that for reasons of the child's health security, presumed low-quality of free vaccine, high level of child mortality after vaccination, religious beliefs and principles, the child's father and she herself refused to provide preventive vaccinations to their son and assumed all the responsibility for the children in the event of negative health consequences in this regard.

The court upheld the claim reasoning it with provisions of paragraphs 1 and 2 of Art. 3 of the Convention on the Rights of the Child ratified by the Verkhovna Rada of Ukraine on February 27, 1991, provisions of Arts. 3, 12 of the Law of Ukraine "On the Protection of Childhood", which practically reproduce provisions of Art. 2 of the Convention on the Rights of the Child of 20 November, 1989, amended by the UN General Assembly Resolution 50/155 of December 21, 1995, ratified by the Resolution of the Verkhovna Rada of Ukraine No. 789-XII of February 27, 1991, as well as in accordance with Art. 9 of the Law of Ukraine "On Pre-School Education" and Protocol No. 1 of the Council of Europe to the Convention for the Protection of Human Rights and Fundamental Freedoms, the Universal Declaration of Human Rights, the European Social Charter, Arts. 8, 19, 46 of the Constitution of Ukraine.

Case, No. 286/2479/16-a (the ruling dated October 11, 2017), in fact, is based on similar circumstances according to a claim filed against a pre-school educational institution No. 10 of the town of Ovruch, Ovruch District Council, Zhytomyr region. The court rendered a judgment with similar reasoning in favour of plaintiffs who refused to provide vaccination to their child. Case No. 286/5524/14-a (the ruling dated September 22, 2014) is based on similar circumstances according to a claim filed against a pre-school educational establishment regarding enrollment of a child without scheduled vaccinations. The court upheld the claim reasoning it as it had been performed in the above example. 
An interesting case was carried out by the Court of Appeal of Khmelnytskyi region (No. 682/1692/17) concerning denying a person of attending a pre-school educational institution in connection with violation of the vaccination schedule.

In its ruling, the court noted that any right objectively corresponds with duties and since the right to pre-school education is linked by the legislator with the duty to undergo preventive vaccinations (which guarantee safety of both the child and people around him/ her), a certificate issued by a medical center which states that the child is healthy and can attend an institution cannot substitute for a conclusion of a medical advisory committee at a medical facility of possibility of attending a pre-school educational institution by children whose parents refuse vaccinations. At the same time, the judicial body takes into account that the defendant's offense does not deprive them of the right to education since they can receive it in other forms.

The right to education declared by Art. 53 of the Constitution of Ukraine provides for certain actions done by this person. In accordance with clause 6 of the Regulations on Pre-school Institution, such actions include submission by a child's parents of an application for enrollment of a child in a pre-school institution, a medical certificate of his / her state of health, a certificate of epidemiological environment issued by a district doctor, a child's birth certificate.

However, rendering judgments in favour of one person neglecting other children's rights to health is evidence of incorrect understanding of the principles of justice by judges and lawyers. And such actions are treated as a consequence of "blind" copying of the ECHR requirements without appropriate clear understanding of the practice of the ECtHR.

\section{Conclusions}

The given data make it obvious that in some cases the state may legitimately restrict certain rights and freedoms by carrying out mandatory immunoprophylaxis, but it is necessary to prove that such restriction of the human right to freedom of choice in healthcare is as follows: 1 ) provided by law and carried out in compliance with it; 2) consistent with such legitimate objectives as public health; 3 ) an absolutely necessary measure to achieve these goals (conformity); 4) necessary in view of lack of less rigid ways to achieve these goals (auxiliary character); 5) conducted not arbitrarily, but fairly and without discrimination.

The above considerations, combined with analysis of the provisions of universal and regional international health-care instruments, give grounds for distinguishing the concept of understanding the right to health as an absolute subjective natural right. This right is directly related to public interests and is not limited to medical intervention, but involves the use of a number of legal, organisational, social measures aimed at comprehensive provision of public health, among which preventive measures to prevent spread of infectious diseases, in particular immunoprophylaxis (immunisation). 
Being a component of state measures in healthcare, immunoprophylaxis has been formed as a result of determining social aspect as the main cause of spread of infectious diseases. That is why most international acts identify prevention and treatment of epidemic, endemic diseases, as well as preventive treatment among top priorities in public health.

The right of a person to freedom of choice in the field of health protection in relation to immunisation meets the duty of the state, firstly, to create conditions for free and unimpeded exercise of such a right by adopting positive measures for the organisation of the system for prevention of infectious diseases, and, secondly, in exceptional cases to take measures to restrict exercise of this right in order to ensure realisation of public interests, national security by, in particular, mandatory vaccination.

\section{Imūnprofilakse veselības aprūpē: cilvēktiesību konteksts}

\section{Kopsavilkums}

Pētījums ir veltīts imūnprofilakses problēmām cilvēktiesību aizsardzības kontekstā. No vienas puses, izmantojot proporcionalitātes principu, autors analizē cilvēka tiesības atteikties no medicīniskiem pakalpojumiem, tostarp vakcinācijas. No otras puses, tiek pētītas citu cilvēku tiesības uz veselības aprūpi saistībā ar infekcijas slimību profilaksi. Autors izmanto Eiropas Cilvēktiesību tiesas praksi, lai argumentētu izdarìtos secinājumus.

Atslēgvārdi: medicīniskā palīdzība, medicīniskais dienests, informēta piekrišana, imūnprofilakse, proporcionalitātes princips.

\section{References}

1. Child Protection Resource: Collecting information, resources and support for everyone involved in the child protection system in the UK. Proportionality and Article 8 of the ECHR. URL: http:// childprotectionresource.online/proportionality-and-article-8-of-the-echr/ [reviewed 14.03.2018].

2. Consil of Europe. Convention for the Protection of Human Rights and Dignity of the Human Being with regard to the Application of Biology and Medicine: Convention on Human Rights and Biomedicine. European Treaty Series - No. 164. Oviedo, 04.04.1997. URL: https://rm.coe. int/168007cf98 [reviewed 14.03.2018].

3. Decretto-Legge 7 giugno 2017, n. 73 (Eng. Decree-Law June 7, 2017, No. 73). URL: http://www. gazzettaufficiale.it/eli/id/2017/06/07/17G00095/sg [reviewed 14.03.2018].

4. European Court of Human Rights. Case of Jehovah's Witnesses of Moscow and others v. Russia. (Application No. 302/02) Strasbourg, 10 June 2010. URL: http://hudoc.echr.coe.int/app/conversion/pdf/?library=ECHR\&id=001-99221\&filename $=001-99221$.pdf\&TID $=$ cnscmzszbt [reviewed 14.03.2018]. 
5. European Treaty Series, 1950, No. 5; United Nation Treaty Series, 213, 221. [Overview of proportionality principle][reviewed 14.03.2018].

6. Gesetz zur Verhütung und Bekämpfung von Infektionskrankheiten beim Menschen (Infektionsschutzgesetz - IfSG) (Eng. Law for the Prevention and Control of Infectious Diseases in Humans (Infection Protection Act - IfSG). URL: https://www.gesetze-im-internet.de/ifsg/IfSG. pdf [reviewed 14.03.2018].

7. Hickler, B., MacDonald, N. E., Senouci, K., Schuh, H. B. 2017. Efforts to monitor Global progress on individual and community demand for immunisation: Development of definitions and indicators for the Global Vaccine Action Plan Strategic Objective 2. Vaccine. 35, 3515-3519. URL: https://www.sciencedirect.com/science/article/pii/S0264410X17305480 [reviewed 14.03.2018].

8. Mrożek-Budzyn, D. 2012. Evolution of Polish immunisation schedule during the last 10 years. Przegl Epidemiol. 66, 107-112 [reviewed 14.03.2018].

9. Panomariovas, A., Losis, E. 2010. Proportionality: from the concept to the procedure. Jurisprudencija. 2(120), 257-272. URL: https://www3.mruni.eu/ojs/jurisprudence/article/view/1075/1028 [reviewed 14.03.2018].

10. Pashkov, V., Gutorova, N., Harkusha, A. 2016. Medical device software: defining key terms. Wiadomości Lekarskie. LXIX, 6, 813-817.

11. Pashkov, V., Harkusha, A. 2016. Certain aspects on medical devices software law regulation. Wiadomości Lekarskie. LXIX, 6, 765-767.

12. Pashkov, V., Hrekov, Y., Hrekova, M. 2017. European experience of regulating distance selling of medicines for Ukraine. Wiadomości Lekarskie. LXX, 1, 96-100.

13. Pashkov, V., Kotvitska, A., Harkusha, A. 2017. Legal regulation of the production and trade of medical devices and medical equipment in the EU and US: experience for Ukraine. Wiadomości Lekarskie. LXX, 3(II), 614-618.

14. Pashkov, V., Olefir, A. 2017. Problems of rehabilitation of mentally ill persons: the international legal aspect (Ukrainian experience). Acta Balneologica. LIX, 4(150), 341-353.

15. Pashkov, V., Olefir, A., Bytyak, O. Y. 2017. Legal features of drug advertising. Wiadomości Lekarskie. LXX, 1, 133-138.

16. Pashkov, V., Soloviov, A., Olefir, A. 2017. Legal aspects of counteracting the trafficking of falsified medicines in the European Union. Wiadomości Lekarskie. LXX, 4, 843-849.

17. Pashkov, V., Udovyka, L., Dichko, H. 2018. International medical law and its impact on the Ukrainian healthcare legislation. Wiadomości Lekarskie. LXXI, 1(II), 201-205.

18. Rights of the Unvaccinated Child: Criminal Law. Feb. 25, 2014. Shot of prevention. URL: https:// shotofprevention.com/2014/02/25/rights-of-the-unvaccinated-child-criminal-law/ [reviewed 14.03.2018].

19. Tatsiy, V., Gutorova, N., Pashkov, V. 2017. Legal aspects of cancer diseases prophylactics: patients' rights context. Wiadomości Lekarskie. LXX, 6(I), 1108-1113.

20. Tsakyrakis, S. 2009. Proportionality: An assault on human rights? International Journal of Constitutional Law. 7(3), 468-493.

21. United Nations. Universal Declaration of Human Right. URL: http://www.un.org/en/universaldeclaration-human-rights/ [reviewed 14.03.2018].

22. WHO Regional Office for Europe. The European Vaccine Action Plan 2015-2020 (EVAP). URL: http://www.euro.who.int/_data/assets/pdf_file/0020/253730/64wd15e_EVAP_140459. pdf [reviewed 14.03.2018]. 


\title{
Tasks of the State and Role of Social Law in the Field of Social Welfare
}

\author{
Dr. iur. Artur Kokoszkiewicz \\ College of Entrepreneurship and Administration in Lublin, Poland \\ artur.kokoszkiewicz@gmail.com
}

\begin{abstract}
The article deals with the issue of state tasks in social sphere and the role of social law in shaping social protection. This is a common subject, as it concerns every legal order of modern democratic legal states (the Western model). Interesting are also the functions that social law has met in the past and present. The article presents legal approach; although due to the importance and universality of the subject, the approach to sociology of law, history and political science has also been hinted at. The first part of the article presents the concept of "social welfare" and social law. The second part focuses on historical outline that helps explain the phenomenon of social welfare being researched. It has been discovered that social law has a very long history, probably related to the beginnings of statehood. Subsequently, a few comments on the tasks of modern democratic legal state of the Western model have been discussed, indicating the diagram of typology of political doctrines showing a number of dependencies. Finally, social welfare models have been described, adding remarks about the role of social law in this area.
\end{abstract}

Keywords: social welfare, social law, state tasks.

\section{Introduction}

Conducting scientific research on the tasks of states in social welfare sector and the role of social law in shaping these tasks, it must be scientifically explained what social care is, why it was created, why it is exercised in various countries, and what determines the form of its exercise. This is a research problem of interest not only in legal science, but also in principle interdisciplinary. Social welfare can be (and is) the subject of interest, for example, in sociology, economics, psychology or political science. Social welfare and social 
law regulating it are present in every state of our cultural circle (Dziewięcka-Bokun, 2000). Significant financial resources are allocated for the implementation of care tasks, which increases the importance of the research problem. Therefore, the article comments on its contributing nature, the title issue regarding the tasks of the state and the role of social law in the field of social welfare.

\section{Concept of Social Protection and Social Law}

Care stands for caring for someone, satisfying someone's needs, guarding someone or something, supervision, custody, guardianship; in addition to care, the term "social welfare" is distinguished, which in colloquial sense means a local institution dealing with environmental aid (Sikorska-Michalak, Wojniłko, 2000). Care is a caring conscientious care for satisfaction of someone's needs, guarding someone or something (Zgółkowa, 2000). Encyclopaedia Britannica, in turn, includes the term "social and welfare services", which can be interpreted as social services, the connotation of which complies with the social welfare discussed. Social care cannot be clearly defined, but it can be assumed that it is based on three main pillars of activity: remedial, preventive and supportive. It is also worth noting that in 1967 a definition of experts of the United Nations (UN) was created in which social assistance is seen as a set of factors that help individuals, groups and societies overcome difficult social situations, the source of which lies in change. In communism, for example, Polish or Latvian, it seems that there was no place for social protection, because the socio-political system then assumed (theoretically and in fact false) full satisfaction of society. There was therefore no need to redistribute income and to provide social welfare, because everyone, of course in theory, was satisfied.

Summarising, we can assume that social care is based on three main principles:

1. the purpose of its programmes is to guarantee minimum income standards for people whose incomes are insufficient;

2. these persons have no other means or access to other means to be able to provide themselves with a minimum income standard;

3. the purpose of these programmes is not to increase the dependence of people on programmes, but to include measures to encourage self-sufficiency and independence (Eardley, 1996).

It seems that in the system of law, which can be referred to as social law (which will be part of the administrative law), there is a number of legal institutions that are part of the social protection (aid) in question. These will include, for example, various types of benefits, child benefits, material support (for example in the form of food or clothes), non-material support (for example, counselling or psychological assistance). 


\section{Historic View}

Social assistance is not a modern invention. Aristotle in work Politics notes that state education of children of fallen soldiers was ensured. In Roman times, cereal was distributed, and in 779, Charlemagne imposed a tax on bishops, princes and vassals, and he obtained public funds for the protection of the poor (Zamorska, 2010). A common form of help to the poor was giving away grain from state granaries at low prices, and sometimes free of charge. Many Romans used this right. During the times of Julius Caesar, their number reached about 300,000 people. In the second century BC, the poor Romans also received olive oil for free, and on special occasions - clothing (e.g., triumphal entry of chiefs) (Mielczarek, 2006).

As one of the reasons for such social protection is mentioned the necessity of helping another person, which is inscribed in the system of law and human values (Sierpowska, 2008). The above claim could be attributed to the common denominator of the "humanistic" origin of social welfare.

However, in Polish legal literature before World War II, it was pointed out, that from a purely egotistic drive, a man began to help his neighbour. Experience has taught that it is necessary to help one's neighbour in disguise to receive such help in the event of misfortune from him. Being aware that old age is unavoidable for every human being, they began to look after the elderly (Zawadzki, 1935). Friedrich von Hayek stated that the need for social care institutions in industrial society is unquestionable; even for protection against acts of desperation on the part of the poor (Zamorska, 2010). Thus, the essence of the above view is that social welfare is a stabilising factor as an element of social policy of the state.

The reasons for shaping social welfare can therefore be seen on the side of the state apparatus, which was vitally interested in having tools to shape the situation the social subordination of society.

The above helps explain the complex nature of the reasons accompanying the development of social welfare. In social care pedigree, one can distinguish (obviously by making a significant simplification) two leading factors: either humanistic or pragmatic in nature. This is even more highlighted by social policy implemented by the EU Member States and its application of social welfare.

\section{Tasks of Modern State}

The current legal tasks of the state include education, higher education, internal and external safety, health care, courts and prosecutors, government and local government administration, state-owned enterprises, agricultural production, trade, services, etc.

The tasks of the state are the result of elementary assumptions that this state accepts. The responsibilities of the modern democratic state of law depend on the state model that the specific state implements. One can point at two opposing models of states perceived through the prism of the tasks assigned to them; the minimum and the maximum state model. 


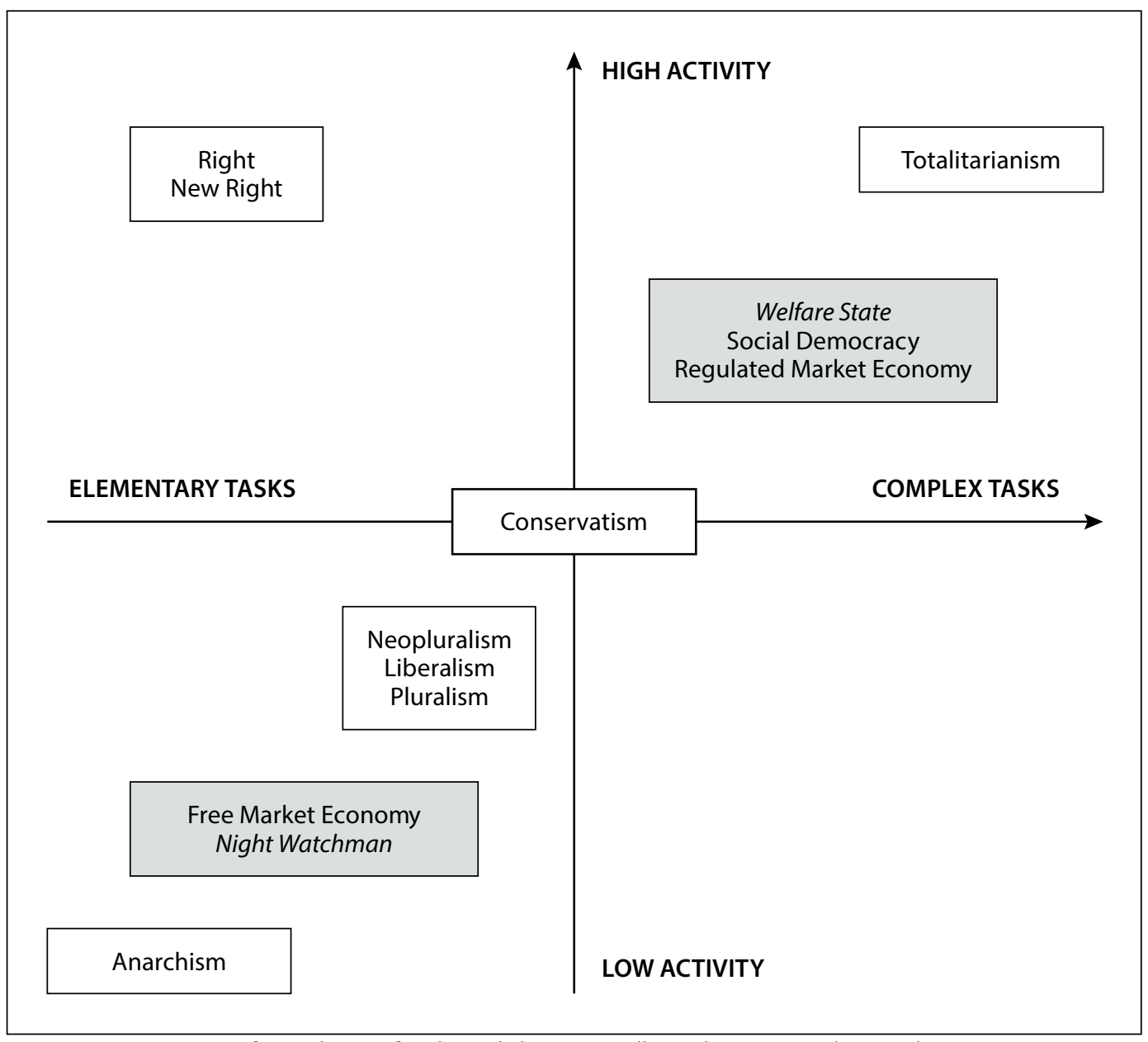

Figure. 1. Diagram of typology of political doctrines (based on Szostak, 1998)

This is the scheme of the typology of political doctrines. Dependencies on two axes can be observed: vertical, where we have state activity in the tasks we perform, from small to large, and horizontal, where we have state tasks, their size, number, from small (elementary tasks) to large (tasks extended) (Held, 2010). Despite its simplification, Figure 1 allows to notice the necessary difference (Żmigordzki, 1987). Depending on variables, different typologies of political doctrines will be dealt with. From the extreme, anarchism, where there are no tasks thus they are not performed; by the doctrines of a free market economy or state as a night watchman; by liberal doctrines, conservatism, welfare state, social democracy with regulated market economy to the next extreme example - totalitarianism - where tasks are carried out in a very complex scope and with high activity (intensity). 
In the case of a minimal state, one can recall the views of Adam Smith contained in the Inquiry into the Nature and Causes of the Wealth of Nations. Smith writes that under the system of natural freedom, the ruler will only have to fulfil three duties. They are, however, duties of great importance, but for this, they are clear and widely understood. First, this is the duty to protect society against rape or invasion by other independent societies. Second, it is the duty to defend any member of society as far as possible from injustice and oppression from all other members of society; that is, the obligation to establish a proper administration of justice. Third, the obligation to establish and maintain certain public facilities, the establishment and maintenance of which can never be in the interest of the individual or a small number of units (Smith, 1954). A similar position can be found, for example, with Milton Friedman (Ptak, 2008) or Robert Nozick (Nozick, 1974) - well-known libertarians and anarchists.

A contrario, a group of maximum state models will be the opposite of the minimal state. In particular, the state will cover many areas with its interference, taking on a paternalistic role. Hagen Schulze, discussing the medieval state of Frederick II, writes that the state wanted to be ubiquitous. Doctors, surgeons, apothecaries, and lawyers had to be approved by the state; their fees were set by the administration. The production and sale of medicines were bureaucratically supervised, and their prices were set out in regulations. Every craft in all its aspects was regulated by laws, everyday life of subjects was rationed, up to regulations concerning the purity of water and air. The state even interfered in private lives of the subjects; marriages with foreigners were forbidden, and marriages of knights and barons required the consent of a ruler. The author states, this was a state of absolutist administration and law (Schulze, 2012).

The maximum model, where the state intervened in many areas of social life is also known for our Polish and Latvian historical experiences.

In Poland and Latvia, for many years we have had a dominant role of the state in areas that we consider to be private today. State factories, industrial production, health care or education (only) and even agricultural production (state agricultural farms), although in this respect, derogations were allowed in Polish communism allowing for private property. Part of the land and farms remained in the hands of the owners.

It can be assumed that the model of a minimal state (or of a liberal character) assumes that only a few tasks are carried out by the state. It seems that these will be tasks necessary for functioning of the state, for example, maintaining the army, law enforcement forces or administration of justice. The state is an instrument of protection, a tool enabling the realisation of particular interests of individuals constituting society. Its opposite is the model of the maximum state, that is, a state that performs numerous tasks, interferes in a number of areas of social life. The state is, therefore, the organiser of social life, which requires individuals to submit themselves to the common goal (which may limit or prevent the realisation of particular interests of individuals constituting society). 


\section{Models of Social Care}

In social care models, the polar division is also outlined: from the minimal model, where social care is largely left in the sphere of charity, to the maximum model, where the state is the organiser of social life and through its institutions redistributes goods to meet citizens' needs.

In the elementary model, the main subject of social welfare is the family, not the state. Social problems are solved at the lowest level, and social assistance is based on charity. The elementary model can be compared to primary social care, which goes back to the principles of private charity.

The "measure" model is sometimes called, among others, "corporate", "conservative", or "motivational". The basic feature of such a model should be the creation of a specialised administrative apparatus responsible for the functioning of social welfare. On the one hand, there are elements of paternalism consisting in the organisation of social welfare by the state. On the other hand, satisfying the human needs follows the criterion of seniority, merit and efficiency.

At the other extreme are the maximum models called "caring", "social democratic" or "Scandinavian" models. The model of this group is characterised by a high degree of paternalism of the state and interference in the social sphere. It is about striving for the state to provide employment and a high level of social services. Social services are extensive and specialised. Social protection covers all citizens from birth to death.

It is worth mentioning that for the implementation of any of the solutions discussed, there is a need for a law. It is the law that is the regulator of social life in this case. It is in law that one will find their normative stipulation of social welfare system, its organisation, benefits, amount, method of payment, etc. As stated, administrative and social law as a rule remains public.

\section{Conclusion}

Models of social welfare serve as one of the tasks of the state. Depending on the model of functioning adopted in a specific country, its tasks - and hence social care can be implemented in a more or less intensive way. Since the article discusses democratic states of the rights of the Western model, one can make the following conclusion (final proposal): social welfare is an element (tool) of social function of every democratic state of law (Dziewięcka-Bokun, 2000).

Every country of this type deals with social protection to a lesser or greater extent. Therefore, countries that provide social welfare state are referred to as welfare states. Recognising the positive, it must be admitted that in contemporary legal and sociological or political thought, the welfare state criticism is dominating (Fukuyama, 2000).

It has been acknowledged that excessive social spending does not have a good impact on society and leads to many pathologies. It seems that criticism of the state's excessive protection is part of the so-called migration crisis that is currently being 
dealt with in the European Union. Wandering of peoples, among others from Africa or the Middle East in search of social care, do not arouse too much enthusiasm of societies.

David Held, who in Democracy Models constructs the theory of an overloaded state (the crisis of the liberal-democratic welfare state regime), has expressed an interesting view in this respect (Held, 2010). He points to the following process: the starting point (welfare state) (1) increases the expectations of citizens (2), which in turn leads to a "crisis of authorities" and increases the aspirations for "even more" (3). Subsequently, social groups are more and more boldly pushing for the implementation of the fragmented goals, forcing the country to take advantage of their political solutions (4). Politicians of all parties seek ad hoc political profits (5), which in turn leads to a further increase in citizens' expectations (6). Governments have a delay policy (7), which increases the number of overdeveloped state agencies (8), which means that the state is losing its ability to manage effectively (9). The ability to generate wealth through the private sphere breaks down (10) and the vicious circle starts, returning to point four (11), or forcing further political solutions by pressure groups. If Held's "vicious circle" is not interrupted during the cyclical repetition of the scheme, the state awaits a multifaceted annihilation (economic, legal, social, ideological).

Thus, an open question arises, where the point of the model is located in individual countries and whether there is a chance to break the cycle. However, this is a topic for successive scientific texts.

\section{Valsts uzdevumi un sociālo tiesību nozīme sociālās labklājības jomā}

\section{Kopsavilkums}

Jautājums par valsts uzdevumiem sociālajā jomā un sociālo tiesību lomu sociālās aizsardzības veidošanā attiecas uz ikvienas mūsdienu demokrātiski tiesiskas valsts (Rietumu modeḷa) tiesisko kārtību. Rakstā tiek aplūkota ne tikai juridiskā pieeja šim jautājumam, bet arī tiesību sociologiijas, vēstures un politologiijas aspekti, n,emot vērā to, kā sociālās tiesības tikušas ievērotas senāk un kā tās tiek nodrošinātas mūsdienās.

Rakstā ir aplūkots sociālās labklājỉbas un sociālo tiesību jēdziens, sniegts vēsturiskais izklāsts, kas palīdz izskaidrot sociālās labklājības fenomenu, un konstatēts, ka sociālajiem likumiem ir l̦oti ilga vēsture, kas, iespējams, ir saistīta ar valstiskuma pirmsākumiem. Rakstā sniegti komentāri par mūsdienu demokrātiski tiesiskas valsts (Rietumu modeḷa) uzdevumiem sociālajā jomā, kā arī aplūkota politisko doktrīnu tipologiija. Visbeidzot, tiek apskatīti sociālās labklājības modeḷi, aktualizējot sociālo tiesību lomu šajā jomā.

Atslēgvārdi: sociālā labklājība, sociālie likumi, valsts uzdevumi. 
Artur Kokoszkiewicz. Tasks of the State and Role of Social Law in the Field of Social Welfare

\section{References}

1. Dziewięcka-Bokun, L. 2000. Systemowe determinanty polityki społecznej (Eng. Systemic Determinants of Social Policy). Wrocław, 131-132.

2. Eardley, T. 1996. Social Assistance in OECD Countries: Synsthises Report. London, 47.

3. Fukuyama, F. 2000. The Great Disruption: Human Nature and the Reconstitution of the Social Order. Warszawa, 58.

4. Held, D. 2010. Models of Democracy. Kraków, 248-250.

5. Kokoszkiewicz, A. 2015. Opieka społeczna jako zadanie państwa. Studium teoretycznoprawne (Eng. Social Welfare as a Task of the State. Theoretical and Legal Study). Lublin.

6. Mielczarek, A. 2006. Polska pomoc społeczna: doświadczenia historyczne (Eng. Polish Social Assistance: Historical Experience). Toruń, 9.

7. Nozick, R. 1974. Anarchy, State and Utopia. Oxford, 26-33.

8. Ptak, P. 2008. Ile państwa w gospodarce?: Milton Friedman o ekonomicznej roli państwa (Eng. How much State in the Economy?: Milton Friedman on the Economic Role of the State). Warszawa, 43.

9. Schulze, H. 2012. Państwo i naród w dziejach Europy (Eng. The State and the Nation in the History of Europe). Warszawa, 27.

10. Sierpowska, I. 2008. Państwo wobec pomocy społecznej. Wrocławskie studia erazmiańskie: Państwo - koncepcje i zadania (Eng. State towards Social Assistance. Wrocław Erasmus Studies: State - Concepts and Tasks). Wrocław, 139.

11. Sikorska-Michalak, A. Wojniłko, O. 2000. Słownik współczesnego języka polskiego, III (Eng. Dictionary of contemporary Polish language, III). Kraków, 226.

12. Smith, A. 1954. An Inquiry into the Nature and Causes of the Wealth of Nations. 2. Warszawa, 339-340.

13. Szostak, W. 1998. Problem "ciężaru państwa”: optymalizacja roli państwa liberalno-demokratycznego (Eng. The problem of the "burden of the state": optimising the role of the liberal-democratic state). Kraków, 182-195.

14. The New Encyclopaedia Britannica in 30 Volumes: Macropaedia volume 16. 1975. Chicago, London, Toronto, Geneva, Sydney, Tokyo, Manila, Seoul, Johannesburg.

15. Zamorska, K. 2010. Prawa społeczne jako program przebudowy polityki społecznej (Eng. Social rights as a programme of remodelling social policy). Wrocław, 206.

16. Zawadzki, J. 1935. Zasady opieki społecznej (Eng. Principles of social welfare). Warszawa, 8-9.

17. Zgółkowa, H. 2000. Praktyczny słownik współczesnej polszczyzny. T. 26 (Eng. A practical dictionary of contemporary Polish, vol. 26). Poznań.

18. Żmigrodzki, M. 1987. Współczesne państwowe systemy polityczne (Eng. Contemporary state political systems). Lublin. 


\title{
Tiesības uz izglïtību: izglìtības skaidrojums tiesību aktos
}

\author{
Mag. iur., Bc. paed. Rihards Ërdmanis \\ Rīgas Stradiṇa universitāte, Juridiskā fakultāte, Latvija \\ 011021@rsu.edu.lv
}

\section{Kopsavilkums}

Tiesības uz izglīiību ir cilvēktiesību neatnemama sastāvdal̦a. Tās garantētas daudzu pasaules valstu konstitūcijā, tostarp arī Latvijas Republikas Satversmē. Šajā rakstā tiek analizētas tiesības uz izglìīibu Latvijā, un tās aplūkotas starptautisko tiesību kontekstā, pētìts arī izglìtîbas termins un tā tiesiskā nozīme. Izglìīibas termins analizēts vēsturiskajā, starpnacionālajā un teleologiskajā rakursā.

Atslēgvārdi: tiesības uz izglīiību, izglītība, izglītības termina tiesiskā nozīme.

\section{levads}

1993. gada Nobela miera prēmijas laureāts Nelsons Mandela (Nelson Mandela) teicis šādus vārdus: "Izglītība ir visspēcīgākais ierocis, ar kura palīdzību mēs varam izmainīt pasauli..." [8,22] Turklāt izglītība nav ierocis, kuru lietojot tas notrulinās vai zaudē savu vērtību, bet tieši pretēji - katru brīdi, kad izglìīiba tiek atbalstīta un veicināta ar vecāku, sabiedrības un tiesību normu palīdzību, tā kḷust vērtīgāka. Izglīiības nozīme cilvēka dzīvē ir nepārvērtējama neatkarīgi no veida, kā tā iegūta - formāli vai neformāli, mācību iestādē vai dzīves skolā.

Šajā rakstā analizētas tiesības uz izglìtìbu, izglìtības termins un to tiesiskā nozīme, par pamatu n,emot kā nacionālo, tā arī starptautisko tiesību regulējumu, judikatūru un tiesību doktrīnu. Raksta mērḳis ir analizēt kategoriju - tiesības uz izglìīibu -, aktualizēt izglìiības tiesisko nozīmi un sniegt izglìiības termina skaidrojumu kā no tiesību, tā arī no socioloğijas un pedagog̣ijas zinātnes skatpunkta. 


\section{Materiāls un metodes}

Raksts sagatavots, balstoties uz pētỉjumu, kurā izmantotas juridiskajā zinātnē vispārpieñemtās pētījuma metodes - tiesību normu interpretācijas metodes: gramatiskā metode, analizējot izglītības termina gramatisko nozīmi, izcelsmi latviešu un citās valodās; salīdzinošā metode, meklējot terminam "izglīiība" kopīgo un atšķirīgo Latvijas un citu valstu tiesību sistēmās. Savukārt teleologiskā metode tika lietota, lai atklātu tiesību uz izglìtību un pašas izglìiības jēgu un nozīmi cilvēktiesību kontekstā, kā arī atspoguḷotu izglìiības mērḳi un saikni ar tiesību zinātni, to savstarpējo mijiedarbību; savukārt vēsturiskā metode tika lietota, lai iepazītu izglìtības vēsturi Latvijā un arī citās valstīs. Vēl tika izmantota zinātniskās literatūras analīzes metode, atklājot pētỉjuma teorētisko kontekstu; izziṇas metode, analizējot izglītības jēdzienu un sintezējot zināšanas par izglìtības procesu un rezultātu. Indukcijas un dedukcijas metode pētỉjumā tika lietota, pētāmo parādību skatot dažādos virzienos, - no vispārīgā uz atsevišḳo un no atsevišḳā uz vispārīgo.

\section{Izglītība un tās tiesiskā nozìme}

Izglītības termins sākotnēji tika analizēts tieši filozofu darbos. Jau Senās Grieḳijas filozofs Platons [20] dialogā "Valsts" pirmo reizi Eiropas vēsturē detalizēti pamatoja izglìtības nozīmi un formulēja izglìtības sociālos mērḳus. Viṇš norādỉja, ka indivīda spējas un noderīgums ir visas valsts jeb visas sabiedrības ieguvums. Savukārt Platona skolnieks Aristotelis [20] precizēja valsts mērḳus izglītībā un audzināšanā. Aristotelis bija pārliecināts, ka likumdevējam ar rūpību jāattiecas pret jaunatnes audzināšanu un izglītošanu, jo tajās valstīs, kurās trūkst rūpības attieksmē pret izglìtības procesu, valsts iekārta cieš zaudējumus. Veltot šiem uzdevumiem nepieciešamo gādību, valsts var tikai iegūt, jo ar izglìīibas un audzināšanas palīdzību tā spēj izveidot kā demokrātisku, tā arī oligarhisku vai citādu valsts iekārtu [27].

Sengrieḳu filozofi meklēja atbildi uz jautājumu par izglītības jēgu un mērḳi, tās labumu gan katram indivīdam atsevišḳi, gan sabiedrībai kopumā. Senajā Grieḳijā izglìtība tika uzskatīta par privilègiju, jo tikai izglītots cilvēks varēja veidot karjeru, iesaistîties politikā un kalpot valstij. Par izglìtības augsto prestižu liecināja privilēgija, ka mācīties lasìt, rakstīt un muzicēt bija ḷauts vien pašu bērniem, bet no iekarotajām teritorijām nākušajiem tas bija aizliegts. Sabiedrības attieksmi pret izglitotību ilustrē šāds nievājošs cilvēka raksturojums: "Viņš neprot ne lasìt, ne peldēt." [16]

Būtiski, ka Senajā Grieḳijā jaunās paaudzes skološanā bija atšḳirīgas pieejas. Piemēram, Spartā skola pildīja valsts pasūtījumu, izglītība bija obligāta un masveida, mācību saturs - vienots, skolēni tika pakḷauti mērḳtiecīgai pedagogu darbỉbai, kas atbilst totalitāras sabiedrības izglīīibas modelim. Savukārt Atēnās uzsvars tika likts uz demokrātiskas izglītības modeli, proti, tika veicināta skolēna individualitātes attīstība, skolēna un skolotāja sadarbība [16, 34]. Spartā bērns vecāku aprūpē bija līdz septiṇu gadu vecumam, 
bet pēc tam viṇam bija jādodas apgūt militāro mākslu. Proti, zēni no septiṇu gadu vecuma tika trenēti ar dažādu uzdevumu palīdzību. To pamatā bija askētisms. Spartiešu zēni mācījās dzīvot kareivju kolektīvo dzīvi. Lasìtprasmei un rakstīšanai tika veltīta mazāka uzmanība nekā fiziskajai un militārajai sagatavotībai [9].

Senajā Romā daudz kas tika aizgūts no Senās Grieḳijas. Sākumā bērni izglītību ieguva ğimenē: māja bija pirmā skola, vecāki - pirmie skolotāji. Seno romiešu giimene bija atbildīga par bērna tikumisko audzināšanu. Senajā Romā, tāpat kā Senajā Griekiijā, izglìtība tika uzskatìta par nepieciešamu, lai veidotu karjeru, pildītu pilsoṇa pienākumu un spētu kalpot savai tēvzemei. Romiešu jaunievedums izglītībā bija tiesību zinātṇu skolas [16]. Arī Senajā Romā valsts atbalsts izglīiībai tika nodrošināts, algojot skolotājus un pieškirot finanšu resursus izglitībai [9].

Tātad pagātnē izglīīibas pieejamība un no tās gūtais labums bija tikai ierobežotai l̦aužu grupai, tā bija Senās Grieḳijas pilsoṇu prerogatīva. Savukārt pakḷauto teritoriju iedzīvotājiem izglītība netika garantēta.

Jau 4.-8. gadsimtā pirms mūsu ēras izglîtības nodrošināšanas uzdevums bija valsts funkcija. Šì valsts funkcija (tāpat kā sociālās aizsardzības, veselības, valsts aizsardzības, kultūras, sabiedriskās kārtības un drošības, vides aizsardzības, ienākumu pārdales, ekonomiskās attīstības stabilizēšanas u. c.) ir saglabājusies līdz pat mūsdienām un tiek uzskatīta par ḷoti svarīgu - valsts pienākums ir panākt, lai katram iedzīvotājam ir reāla iespēja attīstìt un pilnveidot savu personību tā, lai varētu dzīvot cien,pilnu dzìvi, kā arī kḷūt par pilnvērtīgu sabiedrības locekli [17].

Tātad sākotnēji izglītība kā vispārējs labums nebija pieejama visiem, bet tikai noteiktai cilvēku grupai. Ieskats Senās Grieķijas un Romas izglītības attīstībā bija nepieciešams, lai uzsvērtu, ka jau senatnē izglìtiba tika uzskatīta par vērtību, to veicināja valsts, un tās vērtība un nozīme katrā nākamajā cilvēces attīstības posmā palielinājās. Izglìtība ir resurss, kas visos laikos kalpojis cilvēkam.

Viduslaikos izglìtība plašām ḷaǔu masām nebija pieejama. Tā bija dižciltīgo atvašu priekšrocība - skolas bija pieejamas aristokrātu bērniem. Vairākās Eiropas valstīs izglìtỉbu pārraudzīja baznīcas. Spēcīgu ietekmi atstāja Akvīnas Toma teologiski filozofiskā pieeja, kas balstījās uz kristietības doktrīnu, un tās idejas tika pārṇemtas no klasiskās filozofijas, it īpaši - no Aristoteḷa dabas filozofijas jeb natūrfilozofijas. Akvīnas Toma veiktā Aristoteḷa ideju sintēze ar kristīgo ticību ieguva lielu nozīmi viduslaikos un arī vēlāk. Izglitības iegūšana aprobežojās ar piederību konkrētai kārtai jeb sabiedrības grupai, kas gatavojās dzīvot tai raksturīgajos apstākḷos, proti, dižciltīgie apguva to, kas nepieciešams dižciltīgajiem, bet zemnieki un amatnieki - to, kas nepieciešams vinuu kārtai. Izglìtība tika koncentrēta galvenokārt klosteros (klosteru skolās vai gramatikas skolās), un vēlāk visapdāvinātākie un turīgākie turpināja studēt universitātēs. Pirmās izveidojās šādas universitātes: Boloṇas Universitāte Itālijā (sākotnēji tajā varēja studēt vien tiesību zinātni, vēlāk - arī citas), Oksfordas Universitāte Lielbritānijā un Parīzes Universitāte Francijā (sākotnēji uzsvars tika likts uz mākslas zinātṇu apguvi) [14]. 
Kopš 16. gadsimta Rietumeiropā izglītība kḷuva par savam laikam atbilstīgu politiskās lojalitātes un reliĝiskās pārliecības ietekmēšanas “līdzekli”. Šāda izpratne tika veicināta, pateicoties gan Roterdamas Erasmam [12], gan Mārtiṇam Luteram [25], kas savos darbos proponēja šãdu nostāju [23].

Vēsturiski jēdziens "izglìtība" radies 18. gadsimtā, attīstot pedagoǵijas zinātni. Tā autori ir Johans Heinrihs Pestalocijs un Johans Gotfrīds Herders, kuri kopā ar citiem jaunhumānistiem izveidoja izglìtības jēdzienu, noteikdami izglitības ideālu. Viṇi izglîtỉbu uzskatìja par attīstības procesu un rezultātu [17]. Tādējādi savos pirmsākumos šis jēdziens tika saprasts gan kā process, gan arī kā rezultāts.

Angḷu valodā ar vārdu education apzīmē jēdzienu "izglītība". Semantiskā nozīme anglu valodas vārdam education ir no latīnu cilmes vārda éducātio [26]. Izglīitibas jēdziens var tikt skatīts kā vērtību transmisija un akumulētas sabiedrības zināšanas. Šajā nozīmē izglīīiba ir ekvivalenta jēdzienam "socializācija" vai "inkulturizācija" [21].

18. gadsimta vidū Prūsijā pirmo reizi ieviesa obligātu pamatskolas apmeklēšanu, un tagad šì prakse ir gandrīz visā pasaulē - pamata izglìtības obligātums jeb pieejamība tiek veicināta arī starptautiski.

Izglītîbai piemìt divas būtiskas pazīmes - tā ir gan process (darbība, transmisija), gan arī rezultāts (zināšanas, prasmes, vērtības, attieksmes u. tml.), un izglìtỉba tiek regulēta ar tiesību normām. Izglìtîba veicina arī citu sabiedrības labumu attīstîbu, piemēram, augstvērtīgu un pārdomātu politisko lēmumu pien̦emšanu [15].

Angḷu valodas juridisko terminu vārdnīcā terminam "izglìtỉba" (education) sniegts šāds skaidrojums: izglìtība iekḷauj sevī ne tikai mācīšanu, bet arī dzīves prasmju veicināšanu un dzīves patīkamo dalıu, kas, iespējams, ir lieliskākais un labākais, kas raksturīgs cilvēkam [11]. No šīs definīcijas īsti nav saprotams, kas izglìtỉba ir tās juridiskajā nozīmē. Tiek apstiprināts vien tas, ka izglìtība nav tikai mācīšana, bet ir kaut kas vairāk par mācīšanu, ka cilvēka raksturu tā var veidot cēlāku, labāku vai pilnīgāku.

Savukārt Lielbritānijas Izglīîbas likumā [2] izglïtības termins netiek definēts, taču šajā tiesību aktā detalizēti tiek noteikta kārtība šajā nozarē, piemēram, kādam jābūt izglītības saturam, iestādēm, disciplīnai, izglītojamo vecumam, skolotāju kompetencei un sagatavošanai, skolu finansējumam u. tml.

Kanādā izglītỉbas tiesiskajā regulējumā ir līdzīga pieeja, piemēram, Albertas provinces (Province of Alberta) Izglitības likuma [3] preambulā teikts, ka izglìīiba ir demokrātiskas un pilsoniskas sabiedrības pamats, izglìtības loma - attīstìt ieinteresētus (iesaistìties gribošus) domātājus, kas ir kritiski un radoši; kā arī pilsoṇus, kuru rīcība ir augsti ētiska un kuri izrāda ciennu, prot darboties komandā un uztur demokrātijas ideālus, kuriem piemìt uzṇēmēja īpašîbas un kuri, sastopoties ar izaicinājumiem, prot tiem pretoties, spēj būt elastīgi, pielāgoties, uzṇemties risku un izrādìt stingru apṇēmību. Kanādas tiesību aktā tiek noteikts izglìtỉbas ideāls un arī izglïtības vērtības.

Tāda pati pieeja redzama arī Jaunzēlandes 1989. gadā pieṇemtajā Izglìîibas likumā. Tā apjomīgajā tekstā, kas iedalīts 33 nodaḷās, tiek detalizēti reglamentēta visa Jaunzēlandes izglìīibas sistēmas darbība. 
Valstīs, kurās pastāv anglosakšu tiesību sistēma, netiek strikti definēts izglìtības termins, bet tā interpretācija atstāta tiesai. 1954. gadā ASV Augstākās tiesas spriedumā lietā "Brauns pret Topekas izglìtïbas padomi" (Brown v. Board of Education of Topeka 347 U. S. 483 (1954) [7] norādìts, ka izglīīiba, iespējams, ir viena no svarīgākajām valsts funkcijām, ka demokrātiskā sabiedrībā tā ir nozīmīga, ka tā ir pilsoniskas sabiedrības pamats, kā arī - kultūras vērtību nodošanas instruments [7]. Šajā spriedumā ASV Augstākā tiesa (US Supreme Court) izskatija afroamerikānuu skolēnu tiesības mācīties publiskajā skolā, t. i., aplūkoja jautājumu par audzēkṇu segregāciju pēc ādas krāsas. Lietā tika norādīts, ka atsevišķās valsts skolās nav vienlīdzības un tajās netiek aizsargātas afroamerikāṇu tiesības tiesības mācīties kopā ar eiropeīdās rases skolēniem. ASV Augstākā tiesa nosprieda, ka ar segregāciju publiskajās skolās tiek pārkāpta ASV Konstitūcija, t. i., tās 14. grozījums (The Fourteenth Amendment). Lai gan šajā spriedumā ir runa par segregāciju, tomēr tam ir judikatūras nozīme ne tikai ASV, bet arī starptautiskā līmenī. Var secināt, ka valstīs, kur pastāv precedentu tiesības, izglìīibas termina tiesisko nozīmi sniedz tiesas un izglìīibas termins tiek skaidrots plašā nozīmē.

Latvijas Republikas (turpmāk - LR) Izglīīibas likumā ir noteikta izglīîibas termina legāldefinīcija. Izglìtības likuma 1. pantā noteikts, ka izglìtība ir sistematizētu zināšanu un prasmju apguves un attieksmju veidošanas process un tā rezultāts. Izglìtības process ietver mācību un audzināšanas darbību. Savukārt izglītības rezultāts ir personas zināšanu, prasmju un attieksmju kopums [4]. Izglitības terminā tiek ietvertas šeit norādītās pazīmes - process un rezultāts. Par izglītîbas rezultātu tā formālajā izpratnē tiek uzskatīts nevis jebkāds rezultāts, kas varētu rasties arī nejauši, bet gan sistematizētā procesā apgūtas zināšanas, prasmes un attieksmes. Tātad LR Izglìtỉbas likumā par izglīîibu tiek runāts tās šaurākajā nozīmē, t. i., juridiski izglìīibas termins tiek definēts tā šaurā izpratnē, respektīvi, izglìīiba ir formāls, sistematizēts process ar noteiktu rezultātu. Tādējādi izglìtības termina tiesiskā nozīme izriet no LR Izglīīibas likumā noteiktajām pazīmēm.

Tieši izglìtības termina šaurākai nozīmei ir tiesiska nozīme kā nacionālajā, tā arī starptautiskajā regulējumā. Šāda atziṇa rodas tādēl, ka gan starptautiskajās konvencijās, gan nacionālajos tiesību aktos un arī tiesu praksē izglìtības termins tiek saprasts formāli, proti, ka izglītība ir valsts funkcija, kas tiek îstenota ar izglīiības iestāžu darbību, t. i., izglìtojamo, skolotāju, vecāku tiesiskajām attiecībām izglìtîbas jomā. Tādēl tiesības uz izglìtỉbu un izglìtỉbas termina tiesiskā nozīme izriet no formalizētām jeb formālām attiecībām.

Starptautiskā pakta par ekonomiskajām, sociālajām un kultūras tiesībām 13. pantā norādīts: "Izglītības mērḳim jābūt pilnīgai cilvēka personības un tā cien̦as apziṇas attīstībai, un tai jāstiprina cilvēktiesību un pamatbrīvību respektēšana..." [6]

Tātad starptautiskajā kontekstā izglītības mērḳis ir cilvēka personības, cieṇas, kā arī cilvēktiesību un pamatbrīvību atzī̌̌ana un tiesību uz izglìiîbu îstenošana. 


\section{Tiesības uz izglìtību}

Tiesības uz izglītību ir tikai teorētiska konstrukcija, ja tās netiek nostiprinātas tiesību aktos. Tātad tiesības uz izglìīibu iegūst jēgu brīdī, kad tās tiek leǵitimizētas, proti, iegūst likumisko spēku. Valstij ir būtiska loma to aizsargāšanā un īstenošanā, radot piemērotu tiesisko vidi izglītības pieejamībai visiem iedzīvotājiem. Piemēram, tiesības uz izglīīibu Krievijas [28] un arī Latvijas tiesību doktrīnā tiek uzskatītas par otrās paaudzes cilvēktiesībām, kā arī tās nav uzreiz ìstenojamas tiesību sistēmā, jo to ieviešanai nepieciešams noteikts sociālo un ekonomisko apstākḷ attīstības līmenis valstī [24].

Šì doma saskan ar atziṇu, ka izglìîibas sistēma ir cieši saistīta ar ekonomiskajiem, sociālajiem un arī politiskajiem apstākḷiem konkrētā valstī.

\section{Starptautiskie tiesību instrumenti}

Starptautiskais pakts par ekonomiskajām, sociālajām un kultūras tiesībām ir starptautisks tiesību akts, kura satura visapjomīgākā daḷa ir atvēlēta tiesībām uz izglīiību (turpmāk - pakts) [6]. Apvienoto Nāciju Organizācija (ANO), komentējot šo paktu, norādījusi, ka formāla vai neformāla izglìtỉba, kas tiek îstenota privātās vai valsts iestādēs, jāīsteno atbilstoši šĩ pakta 13. pantā noteiktajam mērḳim un uzdevumiem [24].

Pakta 13. panta pirmajā daḷā noteikts:

"Šā pakta dalībvalstis atzīst katra cilvēka tiesības uz izglītību. Tās vienojas, ka izglìtības mērḳim jābūt pilnīgai cilvēka personības un tā cieṇas apziṇas attīstībai un tai jāstiprina cilvēktiesību un pamatbrīvību respektēšana. Tās tālāk vienojas, ka izglītībai jādod visiem iespēja būt pilnvērtīgiem brīvas sabiedrības dalībniekiem, jāsekmē visu nāciju un visu rasu, etnisko un religisisko grupu savstarpēja saprašanās, iecietība un draudzība un jāveicina ANO darbs miera uzturēšanā." [6]

Šajā tiesību aktā norādītais izglìtỉbas mērḳis pēc būtības ir vispārējs un izriet arī no izglìības pedagoǵiskās izpratnes. Proti, izglìīiba ir cieši saistìta ar audzināšanu - bez labas audzināšanas daudz grūtāk sasniegt izglītības mērḳi, arī to mērḳi, kas noteikts pakta 13. panta pirmajā daḷā.

Pakta 13. panta otrajā daḷā teikts:

"Šā pakta dalībvalstis atzīst, ka, lai minēto tiesību pilnīgi īstenotu:

a) pamatskolas izglīiībai ir jābūt visiem obligātai un bezmaksas;

b) visa veida vidējai izglītībai, to starpā tehniskai un vakara vidējai izglìtībai, ir jābūt visiem pieejamai un sasniedzamai ar jebkuriem pien,emamiem lidzekḷiem un it ipaši -, pakāpeniski ieviešot bezmaksas izglītību;

c) augstākai izglìtībai jābūt vienādi pieejamai visiem atbilstoši katra spējām, ar visiem pieņemamiem līdzekḷiem un it īpaši -, pakāpeniski ieviešot bezmaksas augstāko izglītību;

d) pēc iespējas jāsekmē vai jāintensificē elementārā izglītība tiem, kam nav pamatskolas izglìtības vai kas nav beiguši pilnu pamatskolas izglītības kursu;

e) aktīvi jāattīsta visu pakāpju skolu tīkls, jāizveido atbilstoša stipendiju sistēma un pastāvīgi jāuzlabo pasniedzēju materiālie apstākḷi." [12] 
Tiesību doktrīnā tiek prezumēts, ka šādu tiesību uz izglīîibu saturu īstenot droši vien ir spējīga tikai valsts, kas izpilda paktā noteiktās tiesības un pienākumus izglítības jomā. Valsts rada izglìtības sistēmu, kas nodrošina vismaz pamatizglīīibas pieejamību, kas ir minimālais starptautiskajās tiesībās noteiktais standarts. Starptautiskajos cilvēktiesību dokumentos noteikts cilvēktiesību minimums, tāpēc nav pieṇemamas atkāpes no šā minimuma [10], tostarp no tiesībām uz izglìiības minimumu, respektīvi, tiesībām uz pamatizglīîibu. Tiesības uz izglīiỉbu ir neatṇemama cilvēktiesību dal̦a.

Ideolog̣iskā aspektā izglìtîbu var raksturot gan kā cilvēktiesības, gan arī kā līdzekli, kas ir neatñemams un nepieciešams citu cilvēktiesību īstenošanai. Izglītība katram cilvēkam dod iespēju sevi attīstìt, pilnveidot un dzīvot cienpilnu dzīvi [15].

Izglīîiba ir rezultāts, kas ir nepieciešams un neatņemams cilvēka tiesību garants. Bez izglìības ieguves iespējām cilvēka tiesības ir nepilnīgas, jo tās netiek îstenotas pilnībā. Tiesības uz izglìtîbu cilvēktiesību izpratnē tika atzìtas par nozīmīgām daudz vēlāk nekā, piemēram, tiesības uz dzīvību, privātīpašumu, brīvību, tiesisko drošumu, kuras vispirms tika iekḷautas valstu konstitūcijās un starptautiskajos tiesību aktos. Par spìti to nozīmīgumam tiesības uz izglītību daudz vēlāk tika pievienotas citām cilvēktiesībām [19].

Daudzās pasaules valstīs tradicionāli izglìīiba, vismaz pamata un vidējā izglìtîba, tiek uzskatīta par patiesu labumu [18]. Apvienoto Nāciju Organizācijas Bērnu tiesību konvencija [1] un Starptautiskais pakts par ekonomiskajām, sociālajām un kultūras tiesībām [6] ir tiesību akti, kas veicinājuši valstīs tādu tiesisko vidi, kas l̦āvusi ieviest, uzturēt un pilnveidot nacionālās valsts sociālās struktūras, lai îstenotu tiesības uz izglīiību. Latvijas Republika abus starptautiskos tiesību aktus ratificēja 1990. gadā, atzīstot to seviškło nozīmi cilvēktiesību nodrošināšanā [5]. Jānorāda, ka ANO Bērnu tiesību konvencijas 28. pantā [1] noteikts, ka dalībvalstis atzīst ikviena bērna tiesības uz izglīiību, un nolūkā pakāpeniski īstenot šìs tiesības un ievērot vienādu iespēju principu tā garantē tiesības, kas ir loti līdzīgas paktā norādītajām.

Valstīm, kas ir ratificējušas starptautiskos cilvēktiesību dokumentus, ir pienākums nodrošināt šajos tiesību aktos norādīto standartu izglīīibas tiesību jomā. Abus ANO cilvēktiesību aktus Latvija savos normatīvajos dokumentos ir transponējusi, garantējot tiesību uz izglìtibu ikvienam Latvijas iedzīvotājam.

\section{Secinājumi}

1. Senajā Griekijā un Romā izglītība tika uzskatīta par vērtîbu un tika veicināta arī ar valsts palīdzību. Izglìtības vērtība un nozīme pieauga katrā nākamajā cilvēces attīstības posmā. Tā ir resurss, kas vienmēr ir kalpojis cilvēkam. Jau 4.-8. gadsimtā pirms mūsu ēras izglìtības nodrošināšanas uzdevums bija valsts funkcija, kas - tāpat kā sociālās aizsardzības, veselības, valsts aizsardzības, kultūras, sabiedriskās kārtības un drošỉbas, vides aizsardzības, ienākumu pārdales, ekonomiskās attīstības stabilizēšanas u. c. - saglabājusies līdz pat mūsdienām un tiek uzskatīta par loti svarīgu. Valsts pienākums ir panākt, ka ikvienam ir 
reāla iespēja attīstīt un pilnveidot savu personību tā, lai varētu dzīvot cieṇpilnu dzīvi un kḷūt par pilnvērtīgu sabiedrības locekli.

2. Izglìtība ir labums, kas veicina arī citu sabiedrības labumu attīstību, piemēram, augstvērtīgu un pārdomātu politisko lēmumu pieñemšanu.

3. 1954. gadā ASV Augstākās tiesas spriedumā "Brauns pret Topekas izglītības padomi" tiesa atzina, ka izglìtība, iespējams, ir viena no svarīgākajām valsts funkcijām, tā ir nozīmīga demokrātiskā sabiedrībā, kā arī pilsoniskas sabiedrības pamats un kultūras vērtību nodošanas instruments. Valstīs, kurās pastāv precedentu tiesïbas, tiesisko nozīmi izglitības terminam dod tiesas un izglïtïbas termins tiek skaidrots plašā nozīmē.

4. Latvijas Republikas Izglītîbas likumā noteikta izglìtîbas termina legāldefinīcija. Izglīiỉbas likuma 1. pantā teikts, ka izglītība ir sistematizētu zināšanu un prasmju apguves un attieksmju veidošanas process un tā rezultāts. Izglìīibas process ietver mācību un audzināšanas darbību. Izglīīibas rezultāts ir personas zināšanu, prasmju un attieksmju kopums [4]. Var secināt, ka izglītỉbas terminā tiek ietvertas šādas pazīmes - process un rezultāts. Par izglītības rezultātu tā formālajā izpratnē tiek uzskatìts nevis jebkāds rezultāts, kas radies nejauši, bet gan sistematizētā procesā apgūtas zināšanas, prasmes, attieksmes, tātad LR Izglìīibas likumā runāts par izglìtību tās šaurākā nozīmē, respektīvi, tas ir formāls, sistematizēts process ar noteiktu rezultātu.

5. Tieši izglìtības termina šaurākajai nozīmei ir tiesiska nozīme kā nacionālajā, tā arī starptautiskajā tiesiskajā regulējumā. Starptautiskajās konvencijās un arī nacionālajos tiesību aktos, kā arī tiesu praksē izglitīibas termins tiek saprasts formāli, proti, izglìtība ir valsts funkcija, kas tiek ìstenota ar izglìīibas iestāžu starpniecību, t. i., izglītojamo, skolotāju, vecāku tiesiskajām attiecībām izglīiības jomā. Tiesības uz izglìtîbu un izglìīibas termina tiesiskā nozīme izriet tieši no formālām attiecībām.

6. Tiesības uz izglīiîbu ir cilvēktiesības, kuras tiek garantētas un nodrošinātas visiem Latvijas iedzīvotājiem. Daudzu pasaules valstu konstitūcijās, tostarp Latvijas Republikas Satversmē, ir noteiktas tiesības uz izglìīibu. Lai gan tiesības uz izglìiību nav absolūtas (tās drīkst ierobežot), tām ir konstitucionāla vērtība.

\section{Right to Education; the Term Education and Its Legal Aspect}

\section{Abstract}

The article presents the idea of the right to education in the context of Latvian and international laws. The term education has been analysed in a historical, international and teleological perspective. The right to education is an integral part of human rights. 
It is guaranteed by the constitutions of many countries of the world, including the Latvian Constitution (Satversme). The author clarifies the scope of the legal definition of education in the legal system of Latvia, explains the legal significance of education.

Keywords: the right to education, education, legal meaning of the term education.

\section{Avoti un literatūra}

\section{Tiesību akti}

1. Bērnu tiesību konvencija: Apvienoto Nāciju Organizācijas dokuments. Latvijas Vēstnesis. 237(5297), 28.11.2014.

2. Education Act 2011. The National Archives. Iegūts no: http://www.legislation.gov.uk/ ukpga/2011/21/contents/enacted [sk. 07.04.2018.].

3. Education Act, Statutes of Alberta, 2012 Chapter E-0.3. (2017). Alberta. Iegūts no: http:// www.qp.alberta.ca/1266.cfm?page $=$ e00p3.cfm\&leg_type $=$ Acts\&isbncln $=9780779786855$ [sk. 07.04.2018.].

4. Izglitïbas likums: Latvijas Republikas likums. Latvijas Vēstnesis. 343/344(1404/1405), 17.11.1998.

5. Par Latvijas Republikas pievienošanos starptautisko tiesību dokumentiem cilvēktiesību jautājumos: Latvijas Republikas deklarācija. Ziṇotājs. 21, 24.05.1990.

6. Starptautiskais pakts par ekonomiskajām, sociālajām un kultūras tiesībām. 2017. Latvijas Republikas Ârlietu ministrija. Iegūts no: http://www.mfa.gov.lv/ministrija/latvijas-parstavisstarptautiskajas-cilvektiesibu-institucijas/latvijas-republikas-nacionalie-zinojumi-par-starptautisko-konvenciju-izpildi [sk. 19.03.2018.].

\section{Tiesu prakse}

7. Brown v. Board of Education of Topeka, 347 U.S. 483. 1954. Justia US Supreme Court. Iegūts no: https://supreme.justia.com/cases/federal/us/347/483/case.html [sk. 09.02.2018.].

\section{Literatūra}

8. Address by Nelson Mandela at launch of Mindset Network, Johannesburg. 2003. Nelson Mandela. Iegūts no: http://www.mandela.gov.za/mandela_speeches/2003/030716_mindset.htm [sk. 04.04.2018.].

9. Bowen, J. 2003. A history of Western education. 1. London, New York: Routledge.

10. Cilvēktiesību ìstenošana Latvijā: tiesa un administratìvais process. 1998. Rīga: Latvijas Universitātes Juridiskās fakultātes Cilvēktiesību institūts.

11. Curzon., L. B. 1998. Dictionary of law. London [etc.]: Financial Times: Pitman Publ.

12. Erasms, Roterdamas. 2008. Muḷ kības slavinājums. Rīga: Jumava.

13. General Comment No. 13, adopted by Committee on Economic, Social and Cultural rights, provides interpretation and clarification of Article 1 of the International Conventant on Economic, Social and Cultural rights. 1999. Right to education. Iegūts no: http://www.right-to-education. org/resource/cescr-general-comment-13-right-education-article-13 [sk. 21.03.2018.].

14. Gutek, G. L. 2005. Historical and philosophical foundations of education: A biographical introduction. $4^{\text {th }}$ ed. Upper Saddle River, New Jersey, Columbus, Ohio: Pearson / Merrill Prentice Hall.

15. Jarinovska, K. 2011. Izglìtības tiesïbas: Konstitucionālie aspekti Satversmes 112. panta kontekstā. Rīga: Latvijas Universitāte. 
16. Ķestere, I. 2005. Pedagogijas vēsture: skola, skolotājs, skolēns. Rīga, Zvaigzne ABC.

17. Latviešu konversācijas vārdnīca. VII sēj. (1931-1932). Rīga: A. Gulbja apgādībā, faksimilizdevums, Rìga: Antēra, 2000, 13 330. sl.

18. Lee, Sh. E. 2013. Education as a Human Right in the $21^{\text {st }}$ Century. Democracy E Education. 21. 19. M'Bow, A. M. 1979. Introduction. The child's right to education. Paris: UNESCO.

20. Meinvald, C. C. Plato - Greek philosopher. Encyclopaedia Britannica. Iegūts no: https://www. britannica.com/biography/Plato [sk. 11.03.2018.].

21. The New Encyclopaedia Britannica. $15^{\text {th }}$ ed., s. v. "education, history of".

22. The official web site of the Nobel prize. 1993. The Nobel prize. Iegūts no: https://www.nobelprize. org/nobel_prizes/peace/laureates/1993/ [sk. 04.04.2018.].

23. The Routledge companion to education. Ed. by J. Arthur and A. Peterson. Abingdon, Oxon, New York: Routledge, c2012. xvi.

24. United Nations Human Rights Office of the High Commissioner. Iegūts no: http://www.ohchr. org/EN/ProfessionalInterest/Pages/CESCR.aspx [sk. 25.03.2018.].

25. Vēstures terminu skaidrojošā vārdnīca - interaktīvs mācību līdzeklis un uzziṇu vietne internetā. 2013. Vēstures enciklopēdiskā vārdnīca. Iegūts no: http://vesture.eu/index.php/Luters_Martins [sk. 27.02.2018.].

26. Аворецкий, И. Х. 1976. Аатинско-русский словарь: около 50000 слов. Москва: Русский язык.

27. Макарова, Н. И., Наливайко, Н. В. 2004. Насимие - ненасилие в современном образовании. Новосибирск: ИзА-во СО РАН.

28. Фелеральный закон «Об образовании в Российской Федерации». Федеральныцй центр образовательного законодательства. Iegūts no: http://www.lexed.ru/ [sk. 12.04.2018.]. 


\title{
Latvijas Republikas privāttiesību tiesu praksē laiks pāršķirt lappusi analoǵijas jēdziena un satura izpratnes attīstībā
}

\author{
Mg. iur. Rolands Kikors \\ Dukascopy Bank SA (Šveice) un AS Dukascopy Europe IBS, Latvija \\ rolands.kikors@gmail.com
}

\section{Kopsavilkums}

Rakstā tiek analizēta līdzšinējā Latvijas Republikas tiesu prakse, tostarp judikatūra, analogiijas kā juridiskās metodes piemērošanā privāttiesībās. Pareiza analogijas piemērošana vairs nevar tikt saistīta tikai ar analoǵijas jēdziena iegaumēšanu un lietošanu noteiktās situācijās. Svarīgi ir ievērot arī no tiesību viedokḷa nozīmīgos materiāli tiesiskos aspektus, kā arī vērtēt pamattiesību trīskāršo ietekmi katrā konkrētā gadījumā. Apskatot šeit minētos apstākḷus privāttiesību kontekstā, var secināt, ka tiesām ir pienākums izvērtēt, vai labums, ko gūst prāvā uzvarējusī puse, objektīvi ir tāds un ne lielāks, kā tas būtu nepieciešams demokrātiskā sabiedrībā, un vai zaudējušai pusei piespriestais nav lielāks par nodarīto kaitējumu.

Atslēgvārdi: analogija, pamattiesību trīskāršā ietekme, privāttiesības.

\section{levads}

Atkal un atkal pārškirirot Latvijas privāttiesību tiesu prakses materiālus par analogijas piemērošanu un skatot tos par laiku kopš Latvijas Republikas neatkarības atjaunošanas, ar bažām jāvērtē tas, ko tiesas nospriedušas visās tiesu instancēs. Lai gan lietas dalībniekiem privāttiesisku jautājumu risināšanā ir visai lielas iespējas ietekmēt tiesas nolēmumu - šādas tiesības izriet no procesuālajiem normatīvajiem aktiem un Latvijas Republikas Satversmes (turpmāk - Satversme), bieži vien šis aspekts netiek ṇemts vērā un vispārējās jurisdikcijas tiesas analogija tiek piemērota vai nepiemērota patvalịgi, turklāt neievērojot analogijas jēdziena un satura izpētes robežas. Tādēl šajā publikācijā uzmanība pievērsta analog̣ijas piemērošanai tieši privāttiesībās, kurās pusēm netiek piešḳirtas tik lielas tiesiskās aizsardzības iespējas kā administratīvajās tiesībās un krimināltiesībās. 
Rolands Kikors. Latvijas Republikas privāttiesību tiesu praksē laiks pāršḳirt lappusi analogijas jēdziena un satura izpratnes attīstībā

Analog̣ijas piemērošana tiesu praksē juridiskā nozīmē ir visai "bīstama" juridiskā metode, jo kādas personas liktenis tiek izšḳirts nevis tā, kā to likumdevējs expresis verbis ir noteicis, bet gan līdzīgi, proti, mazliet citādi. Pirmšḳietami (prima facie) tas izskatās pretēji Satversmes 91. pantā noteiktajam: "Visi cilvēki Latvijā ir vienlīdzīgi likuma un tiesas priekšā. Cilvēka tiesības tiek īstenotas bez jebkādas diskriminācijas." [4]

Tomēr analogijas piemērošanas gadījumā pastāv gan piesaiste, gan saskaṇa ar likumu, kas tiek pamatota ar tiesību normas mērḳi un jēgumu. Turklāt analogijas slēdziena izejas punkts vienmēr ir jēdziens "līdzība" [48, 98]. Analog̣ija ir arī viena no tām retajām juridiskajām metodēm, uz kuras piemērošanu var paḷauties likumdevējs, ja tas no sevis neatkarīgu iemeslu dẹḷ nav spējis izdot tiesību normas visiem iespējamiem dzīves gadijumiem.

Analogijas kā jēdziena un satura izpratne juridiskajā literatūrā - vismaz Latvijā un Vācijā - ir visai plaši aprakstīta un analizēta. To darījuši vairāki Latvijā pazīstami tiesību zinātnieki, piemēram, E. Meḷkisis [46], J. Neimanis [47, 48], A. Plotnieks [49], E. Kalniṇš [41], G. Slaṇķe [52], kā arī starpkaru Latvijas tiesību zinātnieks V. Sinaiskis [51]. Savukārt Vācijā šim tematam pievērsis uzmanību ievērojamais tiesību zinātnieks J. Esers [39], T. Hellers [40], A. Kaufmans [42], D. Šmalzs [50], F. Budlinskis [37] u. c. Tādējādi interesentiem Latvijā pieejamas ne tikai savas valsts tiesību zinātnieku atziņas, bet arī vācu tiesību zinātnieku pētījumi - pietiekams informācijas apjoms par analogijas jēedzienu un saturu. Vai tas ir arī pilnvērtīgs mācību materiāls, kas ḷauj izprast analog̣ijas jēdziena un satura pareizu piemērošanu reālajā dzìvē? Ar to diemžèl nepietiek, jo modernā sabiedrībā nepieciešams studēt un analizēt arī analogiijas piemērošanas praksi kopsakarā ar mūsdienu modernajām vajadzībām.

Kāpēc uzmanība tiek pievērsta tieši analogijai, nevis kādai citai juridiskai metodei? Tāpēc, ka tiesu praksē analogiija ir visvairāk piemērotā juridiskā metode [49, 313]. Tajā pašā laikā analoǵija ir arī visvairāk kḷūdaini piemērotā juridiskā metode, kas ieskicē diezgan pamatīgas problēmas fizisko un juridisko personu tiesiskajā aizsardzībā tur, kur pusēm per se šāda aizsardzība ir ievērojami mazāka nekā administratīvajās lietās un krimināllietās. Šāds secinājums ir gūts, iepazīstoties ar Latvijas tiesu praksi privāttiesībās, kas izveidojusies pēc neatkarības atjaunošanas. Problēmas ir gan analoǵijas jēdziena un satura nepareizā piemērošanā, gan analogiijas piemērošanā tur, kur nav šādas vajadzības, gan nepiemērošanā tur, kur tas ir vitāli svarīgi. Savukārt bieži vien kḷūdainā analog̣ijas piemērošana un / vai nepiemērošana ir klišejiski iesakṇojoties tiesu praksē, piemēram, privāttiesībās, turklāt tā skar arī cilvēka pamattiesību trīskāršo ietekmi un vairs neatbilst Satversmē garantētajām cilvēka pamattiesībām. Lai gan strīds ir starp divām privātpersonām, cilvēka pamattiesību aizskārums var izpausties arī nepareizi piemērotas vai nepiemērotas analoǵijas un līdz ar to arī kḷūdaina sprieduma veidā.

Raksta mērḳis ir veicināt analog̣ijas jēdziena un satura izpratni ne tikai juridiskajā literatūrā un tiesu praksē, bet arī plašāk, tādējādi stiprinot kā fizisko, tā juridisko personu tiesisko aizsardzību tieši privāttiesībās. Rakstā tiek pierādīts, ka privāttiesisku strīdu daba jau per se izgaismo analogijas piemērošanas problēmas. 
Rolands Kikors. Latvijas Republikas privāttiesību tiesu praksē laiks pāršḳirt lappusi analogijas jēdziena un satura izpratnes attīstībā

\section{Privāttiesību tiesu prakses / judikatūras statistiskā analīze}

Analogijas jēdziena un satura problemātika izriet no Latvijas Republikas privāttiesību tiesu prakses. Turklāt ne tikai no pirmās instances tiesu vai apgabaltiesu prakses, bet arī no Latvijas Republikas Augstākās tiesas (turpmāk - Augstākā tiesa) prakses, tostarp judikatūras. Savukārt, ja kḷūdas var saskatìt judikatūrā, jāpadomā, kāds izglìtības līmenis tiek piedāvāts tiesību zinātṇu studentiem, praktiḳiem un tiesību normu piemērotājiem. Iepazīstoties un analizējot kopumā 72, manuprāt, nozīmīgākos spriedumus kopš Latvijas Republikas neatkarības atjaunošanas, var konceptuāli secināt, ka statistiskie rāditāji ir šādi:

- divās trešdaḷās gadījumu analog̣ija tiek attiecināta uz materiālo tiesību normām;

- vienā trešdaḷā gadijjumu analogija tiek attiecināta uz procesuālo tiesību normām;

- nedaudz vairāk kā 50\% gadījumu tiek piemērota likuma analog̣ija;

- pārējos gadījumos tiek piemērota tiesību analogiija.

Tomēr jānorāda, ka laikposmā no 2016. gada līdz šim brīdim šie rādītāji ir samazinājušies.

Tiesas spriedumos aplūkotajos gadījumos analogijas jēdziena un satura izpratnes problēmas izpaudās šādi:

- tiesas neatškīira likuma analog̣iju no tiesību analogiijas;

- no atsevišķiem nolēmumiem vispār nebija saprotams, kā tiesas nonākušas pie analogiijas piemērošanas / nepiemērošanas secinājumiem;

- atsevišķos nolēmumos netika vērtēti no tiesību viedokḷa nozīmīgi materiāli tiesiskie aspekti, lai lietu varētu objektīvi izspriest;

- tiesas analogiju nepamatoti piemēroja gadijjumos, kuros tas nebija nepieciešams, un nepiemēroja tajos, kuros tas bija nepieciešams;

- tiesas, piemērojot analogiiju, neñēma vērā Satversmē nostiprinātās personu pamattiesības un vienlìdzỉbas un taisnīguma principu.

Analog̣ijas jēdziena un satura izpratnes un piemērošanas problemātika tiesu praksē ir diezgan satraucoša, tādẹl raksta turpinājumā sniegts izklāsts par analogiijas jēdziena un satura pareizu izpratni un piemērošanu kopsakarā ar tiesas piel̦autajām kḷūdām.

\section{Likuma un tiesību analoǵijas nepareiza piemērošana}

Jau no jēdzieniem "likuma analog̣ija" un "tiesību analog̣ija" iespējams vispārīgi secināt, ka likuma analogiija attiecas uz kādu konkrētu likuma normu (ar likuma normu šeit tiek saprasti ārējie normatīvie akti), bet tiesību analog̣ija - uz daudzām tiesībām (tiesības šeit ir jāsaprot plašākā nozīmē), kuras jāpiemēro pēc analoǵijas. Viens no Latvijas tiesību zinātniekiem A. Plotnieks norāda, ka likuma analog̣ija (latīnu val. analogia legis) ir tiesību normas attiecināšana uz gadỉjumu, uz kuru norma pēc tās vārdiskā formulējuma jēgas tieši neattiecas, bet kurš pēc būtiskajām pazīmēm ir līdzīgs normas hipotēzē 
Rolands Kikors. Latvijas Republikas privāttiesību tiesu praksē laiks pāršḳirt lappusi analogijas jēdziena un satura izpratnes attīstībā

aprakstītajam gadījumam [49, 327]. Piemērojot likuma analogiiju, tiek meklēts kopsaucējs starp tiesisko sastāvu un faktisko sastāvu [37, 477]. Papildus tam jānorāda, ka likuma analogija ir individuāla analogiija, kuru piemērojot tiek izmantota noteikta tiesību norma. Pirmkārt, noskaidro tiesību normu, kuras hipotēze visvairāk atbilst faktiskajiem apstākliiem; otrkārt, noskaidro, vai nepastāv slēdziens par pretējo (latīnu val. argumentum a contrario); treškārt, pārbauda, cik stipra ir analoğija un vai tā ir sociāli nepieciešama tās efektivitātes ziṇā; ceturtkārt, veic subsumpciju [54, 96-97].

Turpretī, piemērojot tiesību analogiju (latīnu val. analogia iuris), no vairākiem normatīvajiem noteikumiem tiek izsecināts vispārējs tiesību princips, kurš pēc sava satura un jēgas ir attiecināms uz normatīvajā aktā neregulētu gadỉjumu, tāpat kā uz regulētajiem gadījumiem $[44,383]$. Tiesību analogiijas rezultāts ir vispārējs tiesību princips, par kuru runā kā tiesību tālāku veidošanu, kas izgājusi ārpus iespējamās vārdiskās jēgas, ja tiesneša nolēmums nerada tikai vienu noteikumu vienam konkrētam sastāvam, bet tā radītais noteikums attiecas uz nenoteiktu gadỉjumu skaitu [48, 102]. Vācu tiesību zinātnieks F. Budlinskis norāda arī uz atšḳirību starp analogiijas ceḷā radītajiem vispārējiem tiesību principiem un vispārējiem ("dabiskajiem") tiesību principiem [37, 477]. Proti, ja, piemērojot analog̣iju, faktiskajam sastāvam pēc būtības tiek pielīdzināta tiesību norma ar pilnvērtīgu tiesisko sastāvu un tiesiskajām sekām, tad vispārējie ("dabiskie") tiesību principi satur tikai kādu vispārēju vērtību un uzdevumu, bet atklāts paliek jautājums, kā to precīzi realizēt vai kā atbilstoši piemērot no tā izrietošãs tiesiskās sekas. Tiesu praksē bieži vien tiek runāts arī par tiesību normu analogiju, tomēr tiesas parasti ar to ir domājušas tieši tiesību analog̣iju [51]. Pastāv arī tiesu nolēmumi, no kuriem var izsecināt, ka tiesa, lietojot vārdus "tiesību normu analogija”, jauc likuma analogiju ar tiesỉbu analogiju, nenonākot pie konstruktīva un strikta viedokḷa, kurš analoǵijas veids tad issti jāpiemēro [18].

Tiesu praksē vērojami vairāki spriedumi, kuros tiesas neatšḳir likuma analoǵiju no tiesību analog̣ijas un gala secinājuma izdarī̌̌anai kā pamatojumu izvēlas vienu konkrētu veidu. Piemēram, Cēsu rajona tiesas 2017. gada 12. jūnija spriedums lietā Nr. C11059217 ir tipisks tiesību analog̣ijas piemērošanas gadỉjums, kurā tiesa to ir nosaukusi par likuma analogiiju [16]. Šādi spriedumi aplūkojamā jautājuma kontekstā nav retums, un tie pien̦emti (tas izriet no publiski pieejamās informācijas) vismaz kopš 2013. gada [12, 13, 14, 15, 16, 17, 26, 28, 29, 31]. Spriedumos tika analizēts jautājums, vai personai, kura sasniegusi 18 gadu vecumu un kura studē izglìtības iestādē, un kura pati nespēj sevi apgādāt, šĩ iemesla dēḷ ir tiesības no apgādātāja saṇemt uzturlīdzekḷus. Tiesas secinājumu pamatā tika izmantotas šādas tiesību normas: Civillikuma 179. pants: "Vecāku pienākums ir samērā ar viṇu spējām un mantas stāvokli uzturēt bērnu"; 219. pants: "Nepilngadība abu dzimumu personām turpinās tik ilgi, kamēr tās sasniedz astonpadsmit gadu vecumu" [1] un likuma "Par valsts pensijām" 19. panta ceturtā daḷa: "Par darba nespējīgiem ǵimenes locekḷiem uzskatāmas arī šã panta otrajā un trešajā daḷā norādītās personas, kuras nav sasniegušas 24 gadu vecumu, ja tās laikā, kad iestājusies apgādnieka nāve, vai vēlāk mācās vai studē vispārējās, profesionālās izglìtības iestādēs, koledžās vai augstskolās pilna laika klātienē, izn,emot laiku, kad persona ir pārtraukusi studijas" [7]. Tiesa konstatēja, ka persona, lai 
arī ir sasniegusi 18 gadu vecumu, nevar sevi apgādāt, turklāt šādu iespēju neizslēdz arī minētā likuma "Par valsts pensijām" 19. panta ceturtā daḷa. Tomēr tiesa sprieduma taisīšanas pamatā tieši atsaucās uz likuma analogiiju, lai gan no sprieduma ir acìmredzams, ka tiesa lietas iznākuma panākšanai kopsakarā izvērtēja gan Civillikuma 179. pantu un 219. pantu, gan likuma "Par valsts pensijām" 19. panta ceturto daḷu. Tādējādi tiesa ieguva vispārīgu secinājumu, ka ikviena no iepriekš minētajām tiesību normām satur ko tādu, kas tiek likts galīgā slēdziena taisīšanas pamatā. Tādēl šeit nevar runāt par likuma jeb individuālo analogiiju, bet tā ir tiesību analog̣ija. Papildus minētajam jānorāda, ka sabiedrībā varētu rasties jautājums, kāpēc publiskot šādu tiesas piel̦autu kḷūdu, ja neatkarīgi no tā, vai tiesa atsaucas uz likuma analoǵiju vai tiesību analoǵiju, sprieduma iznākums paliek nemainīgs? Atbilde ir pavisam vienkārša - vienotas tiesu prakses, doktrīnas un izpratnes par analogijias jēdziena un satura metodoloǵisko piemērošanu veidošanai ir nepieciešams veicināt sabiedrisko diskusiju par šādām problēmām, lai esošie un topošie tiesību zinātnieki un tiesību normu piemērotāji būtu motivēti izglìtoties un praktizēt tiesu sistēmā, kurā viṇi var paḷauties, ka juridiskā kvalitāte gan kopumā, gan analogiijas piemērošanā ir visaugstākajā līmenī.

\section{Nepietiekama analīze un vērtēšana}

Nepietiekama analogijas satura un jēdziena analīze daudzos gadījumos var būt ne tikai iemesls nepareiza sprieduma pien,emšanai, bet arī turpmākai gan tiesas, gan ārpustiesas strīdu risināšanai. Turklāt sprieduma objektivitātes trūkums var izpausties arī tajā, ka tiesas nevērtē no tiesību viedokḷa nozīmīgos materiāli tiesiskos aspektus, lai vispār nonāktu pie analog̣ijas piemērošanas. No tiesību viedokḷa nozīmīgi materiāli tiesiskie aspekti ir tie, kas vienoti un bez pretējas tagadnes izpratnes atzìti kā ārējos normatìvajos aktos, tā arī doktrīnā un judikatūrā. Tas nozīmē, ka tiesību normu piemērotājam pirms galīgās izšḳiršanās par analoǵijas piemērošanu jāapsver, vai argumentācija, ar kuru pamato tiesību normu piemērotāja secinājumus, nav pretrunā ar citām tiesību normām, vispārējiem tiesību principiem, doktrīnu un judikatūru. Vienlaikus tiesnesim jāapsver, kādas juridiskās sekas tiks radītas sprieduma adresātam un vai šīs sekas bez papildu argumentācijas nebūs acīmredzamā pretrunā ar pastāvošajiem uzskatiem.

Piemēram, Augstākā tiesa kādā spriedumā atzina, ka arī rakstiski nenoslēgtiem darba līguma grozījumiem pēc analogiijas ir piemērojams Darba likuma 41. pants, kurā ir akcentēta rakstiski nenoslēgta darba līguma atzīšana un ietērpšana rakstiski [22]. Šo Augstākās tiesas atziṇu savā argumentācijā izmantoja pirmās instances tiesa un apelācijas instances tiesa, ko var konstatēt no cita Augstākās tiesas sprieduma - 2015. gada 26. janvāra sprieduma lietā Nr. SKC-1650/2015 [23]. Tomēr pati Augstākā tiesa šo apstākli nevērtēja un atzina, ka šajā gadïjumā nav piemēroja ma analogiija. Problēmu radīja tas, ka minētie darba līguma grozijumi, kuri, pēc pirmās un apelācijas instances tiesas ieskata, de facto atbilst analogiijai ar Darba likuma 41. pantu, bija tādi, kas acīmredzami pasliktina darbinieka tiesisko stāvokli. Augstākā tiesa šo apstākli neṇēma vērā, tomēr tai bija 
pienākums izvērtēt, vai šis ir tas gadījums, kurā darba līguma grozỉjumus, kas acīmredzami pasliktina darbinieka tiesisko stāvokli, ir vērts apspriest saistībā ar analog̣ijas piemērošanu. Ja tas būtu vērtēts, Augstākā tiesa, iespējams, nonāktu pie secinājuma, kurš veicinātu daudzpusīgu diskusiju turpmākajos ārpustiesas un tiesas strīdos, jo šādi darba līguma grozījumi nav piemērojami pēc analogijas ar Darba likuma 41. pantu.

To var pamatot arī ar taisnīguma principu. Latviešu tiesību zinātnieks E. Meḷkisis norādīijis, ka taisnīguma princips ir pamatā dzīves gadījuma faktiskā sastāva līdzībai ar normas tiesisko sastāvu, proti, ka līdzīgi gadījumi ir izšḳirami līdzīgi [46, 60], pamatojoties uz Satversmes 91. pantu. Arī vācu tiesību zinātnieks R. Cipēliuss uzskata, ka, piemērojot analoǵiju, jāievēro taisnīguma princips [55, 62], pretējā gadījumā tas būtu netaisnīgi visos analoğiskajos gadỉjumos, piemēram, minētā Augstākās tiesas sprieduma kontekstā - rakstiski nenoslēgti darba līguma grozijjumi tiktu atzîti un noslēgti rakstiski pēc analogijas ar Darba likuma 41. pantu.

Papildus jānorāda, ka arī Augstākās tiesas 2012. gada 25. janvāra spriedumā lietā Nr. SKC-18/2012 ir saskatāmas zināmas analogijas jēdziena un satura piemērošanas problēmas [22]. Šajā spriedumā Augstākā tiesa pēc analogijas piemēroja Civilprocesa likuma 406. pantu, kas tolaik sastāvēja no vairākām daḷām, un ne visas no tām attiecās uz konkrēto gadïjumu [2].

Izprotot likuma analogiiju, ne vienmēr jāaprobežojas tikai ar kādu konkrētu likuma pantu, dal̦u vai punktu, bet gan tieši ar to tiesisko sastāvu, kuru var pēc visām nepieciešamajām līdzībām pakārtot faktiskajiem apstākḷiem. Tādējādi, skrupulozi neizvērtējot, kuras vārdkopas attiecas uz konkrēto dzìves gadījumu un ir piemērojamas pēc analogijas, var, pirmkārt, nonākt pie nepareiza secinājuma; otrkārt, radīt problemātiku tiesību normu piemērotājiem piemērot to pašu normu pēc analogijas un atsaukties uz šīm tiesas atziṇām nākotnē.

Visbeidzot, kādā citā Augstākās tiesas spriedumā - 2003. gada 5. novembra spriedumā lietā Nr. SKC-534 - tiesa secināja: ja darbinieks uzreiz pēc prettiesiskas atlaišanas ir strādājis citā, mazāk apmaksātā amatā, tad pēc analogiijas ar Darba likuma 126. panta otro dalı darbiniekam ir tiesības tikai uz starpību starp jaunā darba samaksu un iepriekšèjā darba vidējo izpeḷnu [18]. Tomēr Augstākā tiesa neizvērtēja šādus no tiesību viedokḷa nozīmīgus materiāli tiesiskos aspektus: pirmkārt, vai darbinieks līdztekus iepriekšējai darbavietai ir strādājis citur (šis apstāklis būtu n,emams vērā, lai noteiktu kopējo tajā laikā saṇemto atalgojumu un aprēḳinātu izmaksājamo starpību); otrkārt, vai darba devējs var palikt nesodìts gadỉjumā, ja viņš ir patvaḷigi rīkojies un darbiniekam vidējās izpel̦nas starpība neveidojas (jo citu tiesiskās aizsardzības līdzekḷu, ja netiek pierādīta atšḳirīga attieksme vai diskriminācija, darbiniekam nav). Tādējādi Augstākās tiesas spiedums, vismaz daḷēji, nav pareizs un minētā Augstākās tiesas nostāja būtu jāpārskata, kā tas jau minēts nesenajā tiesību doktrīnā [43]. 
Rolands Kikors. Latvijas Republikas privāttiesību tiesu praksē laiks pāršḳirt lappusi analogiijas jēdziena un satura izpratnes attīstībā

\section{Analoǵijas nepamatota piemērošana un nepiemērošana}

Tiesu praksē bieži vien vērojama tendence bez īpašas analīzes piemērot analoǵiju tur, kur nav nepieciešams, bet nepiemērot tur, kur ir nepieciešams. Viens no šãdas rīcības iemesliem ir tiesas nepareizā izškirš̌anās, vai konkrētajā lietā ir piemērojama kāda no tiesību normu iztulkošanas metodēm vai arī jāizvēlas tiesību tālāka veidošana. Robeža starp abām minētajām tiesību normām vienmēr ir to vārdiskajā jēgā [53, 128]. Turklāt tiesas līdz galam neizvērtē taisnīguma principu un arī to, vai konkrētā tiesību normas piemērošanas konstrukcija vispār attiecas uz analogiju juridiskā nozīmē.

Piemēram, Bauskas rajona tiesa 2016. gada 1. novembra spriedumā lietā Nr. C10072815, konstatējot, ka prasītājs nav pilnīgi samaksājis valsts nodevu, piedzina šo nodevu par labu valstij no atbildētāja, pēc analogijas piemērojot Civilprocesa likuma 42. panta pirmo daḷu: "[..] ja prasītājs no to samaksāšanas bijis atbrīvots [..]." Tomēr šis tiesas secinājums ir kḷūdains, jo šajā situācijā tiek pārkāpts taisnīguma princips. Proti, likumā ir regulētas situācijas, kurās prasītājs no valsts nodevu samaksas ir atbrīvots, piemēram, trūcīgā statusa dẹl. Savukārt šajā gadījumā tiesa lēmuma par lietas ierosināšanu pieṇemšanas brīdī neatstāja prasības pieteikumu bez virzỉbas un šo savu kḷūdu piesprieda atbildētājam, kurš faktiski varēja paḷauties, ka prasītājs par civilprocesu norēḳināsies saskaṇā ar likumu. Tā vietā tiesa piesprieda šĩs naudas summas iekasēt no atbildētāja.

Jau iepriekš šajā rakstā tika norādīts, ka analoǵijas piemērošana pamatojas uz taisnīguma principu. Tādēḷ pirms analog̣ijas piemērošanas tiesai bija jāizvērtē, vai šāda izšḳiršanās ir taisnīga un atbilstoša. Savukārt kādā citā spriedumā Latgales apgabaltiesas Civillietu tiesas kolēgija noraidīja analoǵiju, kā vienīgo argumentu izmantojot šādu viedokli: "[..] analogiija šajā gadījumā nav piemērojama, jo minētā tiesību norma neregulē pušu tiesiskās attiecības." [17] Rezultātā kḷūdains ir arī spriedums. Ja tiesību norma regulētu pušu tiesiskās attiecības, tad analogiijas piemērošana nebūtu nepieciešama, pietiktu minēto normu iztulkot. Savukārt, ja minētā norma neregulē pušu tiesiskās attiecības, tad jāmeklē lïdzības starp tiesību normu un gadījumu no dzīves. Tad, iespējams, būtiskie apstākḷi sakristu un analogiija būtu piemērojama.

Visbeidzot, kādā no spriedumiem tiesa ir palaidusi garām atbildētāja ierosinājumu pēc analoğijas piemērot nepārvaramu varu, kura, kā to sacījis atbildētājs, nav definēta Civillikumā, tāpēc tā jāaizṇemas no UNIDROIT starptautiskajiem komerclīgumu principiem [8]. Tomēr jānorāda, ka saskaṇā ar analogiijas teoriju nepārvarama vara kā nenoteikts juridisks jēdziens nav piemērojama pēc analog̣ijas, un tiesību normu, kura satur nenoteiktu juridisku jēdzienu, nevar piemērot pēc analogiijas, ja par analoǵijas piemērošanas apstākli tiek izmantots tieši nenoteikts juridisks jēdziens. Analogiija ir tiesību tālākas veidošanas paṇēmiens atklāto likuma "robu" aizpildīšanai [41, 326]. Savukārt nepārvarama vara, kā to norādījis ievērojamais latviešu tiesību zinātnieks E. Levits, vispirms jāpiepilda ar konkrētu saturu konkrētā gadījuma kontekstā $[45,166]$. Ja minētais gadījums neatbilst nepārvaramas varas definīcijai, tad nav konstatējami nepārvaramas varas apstākḷi. 
Un tieši tāpēc, ka nenoteikts juridisks jēdziens pirms tā piemērošanas jāaizpilda ar saturu, konkrētajā gadỉjumā analog̣ija nav piemērojama, jo nepastāv atklāts likuma "robs".

Nenoteikti juridiski jēdzieni nav piemērojami pēc analogijias, līdzīgi jāizturas arī pret tiesību normām, kuras satur generālklauzulas (piemēram, labi tikumi, laba ticība). Tās nav piemērojamas pēc analog̣ijas, ja minētā generālklauzula tiek izmantota par analogiijas piemērošanas apstākli. Šāds secinājums ir cieši saistīts ar generālklauzulu jēdziena izpratni, proti, šie jēdzieni pirms to piemērošanas ir jāpiepilda ar konkrētu saturu visai kazuistiskā veidā, meklējot universālas un juridiski abstraktas vadlīnijas [45, 162-205]. Jānorāda gan, ka ne vienmēr tiesa, analoǵiju nepamatoti piemērojot vai nepiemērojot, lietu izspriež nepareizi. Tieši pretēji - sprieduma gala rezultāts dažkārt ir pareizs un taisnīgs, tāpēc apstrīdēt tā būtību uz analogiijas nepareiza jēdziena un satura izpratnes pamata nebūtu pareizi.

\section{Normatīvā regulējuma, kas transformēts salīdzināmā tiesību sistēmā, piemērošana pēc analoǵijas}

Diezgan maz ir apskatīts jautājums par tiesiskām attiecībām, kas citā salīdzināmā tiesību sistēmā radušās pirms sprieduma pien̦emšanas un uz kurām agrāk attiecās pavisam cits normatīvais regulējums. Pēc analogijas jāpiemēro jaunāks normatīvais regulējums, kas pien̦emts jaunā tiesību sistēmā. Viens no šādiem prakses gadījumiem ir strīds starp Latvijas Republikas Kultūras ministriju un AS "Rīgas Kinostudija" [24], kas sabiedrībā guva plašu rezonansi. Augstākā tiesa vērtēja, vai prasītājam - Latvijas Republikas Kultūras ministrijai - pieder īpašuma tiesības uz AS "Rīgas Kinostudija” uzṇemtajām filmām, kuras tika radìtas pirms Latvijas Republikas neatkarības atjaunošanas, t. i., Padomju Latvijas laikā. Kultūras ministrijai viens no argumentiem bija šāds: vēl pirms Latvijas Republikas neatkarības atjaunošanas filmas, par kurām ir strīds, pārgāja valsts īpašumā, tātad arī pēc neatkarības atjaunošanas tām jābūt valsts īpašumā. Pamatojumā tika norādīts Latvijas Republikas Augstākās Padomes 1993. gada 11. maija lēmuma "Par Latvijas Republikas likuma "Par autortiesībām un blakustiesībām" spēkā stāšanās kārtību" 8. punkta 2. apakšpunkts: "Uzdot Latvijas Republikas Ministru Padomei līdz 1993. gada 15. maijam iesniegt Latvijas Republikas Augstākajai Padomei likumprojektu par valsts īpašumā esošo audiovizuālu darbu tālākas izmantošanas kārtību, n,emot vērā šā likuma 11. pantā noteiktās autortiesības." [6]

Tomēr Augstākā tiesa secināja:

"Apsverot vēlākā normatīvā regulējuma attiecināšanu uz juridisko personu autortiesībām pēc analogiijas, proti, tā transformāciju salīdzināmā tiesību institūtā, kas atbilst Latvijas tiesību sistēmai, ṇemams vērā, ka likumdevējs Latvijas Republikas Augstākās Padomes 1993. gada 11. maija lēmumā "Par Latvijas Republikas likuma "Par autortiesībām un blakustiesībām” spēkā stāšanās kārtību” 8. punkta 2. apakšpunktā pauda noteiktu gribu jautājumā par, tā ieskatā, valstij piekritīgām filmām regulēt ar atsevišksu normatīvo aktu. Neraugoties 
Rolands Kikors. Latvijas Republikas privāttiesību tiesu praksē laiks pāršḳirt lappusi analogijas jēdziena un satura izpratnes attīstībā

uz lēmumā izmantoto neprecīzo izteiksmi [ar to, visticamāk, tiesa domāja to, ka lēmuma 8. punkta 2. apakšpunktā ir minēti valsts īpašumā esoši darbi - R. K.], secināms, ka likumdevējs jautājumu par strīdus periodā radītajām filmām bija vēlējies regulēt patstāvīgi. Atbilstošs normatīvais regulējums nav pienemts līdz pat šim brīdim. 2010. gadā pienemot Filmu likumu, likumdevējs noregulēja tikai jautājumu par valstij jau piederošu tiesību izmantošanu, taču attiecībā uz strīdus periodā tapušajām filmām nenoteica to veidošanā iesaistīto subjektu tiesību veida, apjoma, aizsardzības ilguma un piederības jautājumus. Šādos apstākḷos, kad likumdevējs ir paudis gribu tiesisko situāciju regulēt pats, analogija nav piemērojama, un juridisko personu autortiesības atzīstamas par pārstājušām pastāvēt vēlākais ar likuma "Par autortiesībām un blakustiesībām” spēkā stāšanās brīdi." [24]

Sprieduma pareizība nav apstrīdama, tomēr ir nepieciešams attīstīt šo Augstākās tiesas argumentāciju atbilstoši analogiijas jēdziena un satura izpratnei. Proti, ja reiz Augstākā tiesa secināja, ka minētais Latvijas Republikas Augstākās Padomes lēmums ir uzrakstīts neprecīzi un nav noregulējis juridisko personu autorību, tad log̣iski rodas jautājums, kā un vai ir nepieciešams noregulēt Latvijas Republikas kā sākotnējās juridiskās personas tiesības uz filmām. Atbilde meklējama tajā, ka pēc Latvijas Republikas neatkarības atjaunošanas tiesību sistēma tika transformēta un padomju laika tiesību akti vairs nav juridiski saistoši. Tādējādi izveidojas situācija, kurā juridiski nepastāv tiesiskās attiecỉbas, kurām pēc analog̣ijas varētu piemērot Latvijas Republikas Augstākās Padomes lēmumu, un tātad a priori nevar runāt par kādu tiesību tālāku veidošanu, jo tiesību tālākai veidošanai nav juridiskā pamata.

\section{Pamattiesību trejkāršā ietekme - būtisks priekšnoteikums analoǵijas jēdziena un satura metodoloǵiski pareizai piemērošanai}

Mūsdienās analog̣ijas piemērošanai vairs nav tikai teorētiska nozīme, kas pamatota ar pareizu jēdziena un satura izpratni. Metodoloǵiski pareizas piemērošanas pamatā ir arī Satversmē nostiprinātās pamattiesības, kuras jāievēro ne tikai administratīvajām tiesām un krimināltiesām, bet arī vispārējās jurisdikcijas tiesām, kurām, izskatot horizontālos strīdus, jāṇem vērā arī personu pamattiesības. To, ka konstitucionālās tiesības aizsargā arī analogiijas piemērošanu privāttiesībās, pamato Satversmes tiesas 2001. gada 5. decembra spriedumā lietā Nr. 2001-07-0103 minētais:

"Cilvēktiesību aizsardzība kā viena no tiesiskas valsts svarīgākajām garantijām nosaka valsts pienākumu nodrošināt efektīvu aizsardzību ikvienam, kura tiesības ir pārkāptas. [..] Konstitucionālās tiesības aizsargā gan privātpersonu intereses, gan ar īpašumu saistītās sabiedriskās attiecības, kā arī konstitucionālās tiesības piešḳir tiesības tiešajiem tiesisko attiecību dalībniekiem aizsargāt savas konstitucionālās tiesības. [..] Kā jebkura cilvēktiesību norma, arī Satversmes 92. panta trešajā teikumā ietvertā tiesību norma ir piemērojama tieši un nepastarpināti. Bez tam šì norma neparedz, ka tās konkretizēšanai nepieciešams īpašs likums. Šãda likuma neesamība ir saistāma ar Satversmes 92. panta trešā teikuma tiešas piemērošanas iespēju un nevar būt iemesls atteikumam pieṇemt tiesā indivīda prasību par atlīdzinājuma piedziṇu." [36] 
Lìdzīgu nostāju ir paudusi arī Augstākā tiesa savā 2009. gada 20. maija spriedumā lietā Nr. SKC-383/2009: "Darbinieku pret psihologiisko teroru aizsargā ne tikai Satversme, bet arī Darba likums." [20]

Log̣iski izriet, ka darbinieku pret otru privāttiesību subjektu - darba devēju - aizstāv arī Satversme. Arī Latvijas tiesību zinātnieks Dr. iur. Edvīns Danovskis norāda, ka cilvēka pamattiesību ietekme privāttiesiskajās attiecībās vairs netiek apšaubīta [38, 118-130]. Kā vienu no šeit analizētajiem spriedumiem pamattiesību trīskāršās ietekmes kontekstā jāmin Augstākās tiesas Civillietu departamenta 2006. gada 14. jūnija lēmumu lietā Nr. SKC-488 19], kurā Augstākā tiesa secināja: "Līdz ar to netiek sasniegts likuma mērkis garantēt procesa dalībniekiem tiesības pārsūdzēt tiesas lēmumu saskaṇā ar Civilprocesa likuma 449. panta trešo dalı un Satversmes 92. pantu."

Savukārt par kḷūdainu un no pamattiesību viedokḷa prettiesisku spriedumu ir uzskatāms jau šajā publikācijā pieminētais Augstākās tiesas 2003. gada 5. novembra spriedums lietā Nr. SKC-534 [18], kurā tiesa, neizvērtējot Satversmes 106. panta saturu, nevietā piemēroja analogiju, kura šajā gadijjumā pavisam noteikti nebija nepieciešama. Papildus jānorāda, ka analogiijas jēdziena un satura metodologiijas īpatnības privāttiesībās jāskata kopā ar Satversmē nostiprināto taisnīguma un vienlīdzības principu. Ja izveidojas situācija, kurā tiek atklāts likuma "robs", pirmkārt, detalizēti jāizvērtē, vai pastāv analogijas piemērošanas sākotnējie priekšnoteikumi kopsakarā ar izskatāmo dzīves gadījumu; otrkārt, jāṇem vērā arī Satversmē nostiprinātās garantijas likuma "roba" aizpildīšanā; treškārt, atsevišḳi jāizdara nepieciešamie apsvērumi par taisnīguma un vienlīdzības principa ievērošanu un piemērošanu. Ja kāda no trīs elementiem trūkst vai kāds netiek pilnībā izpildīts, pastāv iespēja, ka tiesa var izdarìt kḷūdainu secinājumu un šādā veidā a priori aizskart personas pamattiesības.

\section{Secinājumi un priekšlikumi}

1. Analizējot Latvijas tiesu praksi / judikatūru, kas izveidojusies kopš Latvijas Republikas neatkarības atjaunošanas, var secināt, ka analoğija ir visvairāk kḷūdaini piemērotā juridiskā metode. Šādas kḷūdas rada visai pamatīgas problēmas fizisko un juridisko personu tiesiskajā aizsardzībā gadỉjumos, kuros pusēm per se šāda aizsardzība ir ievērojami mazāka nekā administratīvajās lietās un krimināllietās.

2. Analog̣ijas jēdziena un satura izpratnes metodologijas problēmas ir saskatāmas gan analoğijas jēdziena un satura nepareizā piemērošanā, gan analoǵijas piemērošanā gadijjumos, kuros tas nav nepieciešams, un analog̣ijas nepiemērošanā tajās reizēs, kad piemērošana ir vitāli svarīga.

3. Bieži piel̦autā kḷūdainā analogiijas jēdziena un satura izpratne, klišejiski iesakṇojoties tiesu praksē, piemēram, privāttiesību kontekstā, skar arī cilvēka pamattiesību trīskāršo ietekmi un vairs neatbilst Satversmē garantētajām cilvēka pamattiesībām, kuras tiesām jāṇem vērā metodologiski pareiza nolēmuma sagatavošanā. 
Rolands Kikors. Latvijas Republikas privāttiesību tiesu praksē laiks pāršḳirt lappusi

analogiijas jēdziena un satura izpratnes attīstībā

4. Ja izveidojas situācija, kurā atklāts likuma "robs", pirmkārt, detalizēti jāizvērtē, vai pastāv analog̣ijas piemērošanas sākotnējie priekšnoteikumi kopsakarā ar izskatāmo dzīves gadījumu; otrkārt, jāṇem vērā arī Satversmē nostiprinātās garantijas likuma "roba" aizpildīšanā; treškārt, atseviškłi jāizdara nepieciešamie apsvērumi par taisnīguma un vienlīdzības principa ievērošanu un piemērošanu.

\title{
It is Time to Turn Over a New Page in Evolution of Understanding the Concept and Matter of Analogy in Private Law Court Practice in the Republic of Latvia
}

\begin{abstract}
In the article, past practice and judicature of the courts of the Republic of Latvia on the implementation of analogy method have been studied. Correct implementation of analogy method cannot include mere memorisation and implementation of it in particular situations. It is also important to consider substantial material law aspects and evaluate the presence of the triple influence of human rights in each private legal relationship separately. By reviewing previously mentioned aspects in the scope of private law, courts have a duty to evaluate whether in democratic society one of the parties is satisfied as much as possible, but the other party must not suffer more than it did any damage to the first.
\end{abstract}

Keywords: analogy, triple influence of human rights, private law.

\section{Avoti un literatūra}

\section{Tiesību akti}

1. Civillikums: Latvijas Republikas likums. Valdības Vēstnesis. 41, 20.02.1937. Iegūts no: https:// likumi.lv/doc.php?id=225418 [sk. 13.04.2018.].

2. Civilprocesa likums: Latvijas Republikas likums. Latvijas Vēstnesis. 326/330(1387/1391), 03.11.1998. Iegūts no: https://likumi.lv/doc.php?id=50500 [sk. 13.04.2018.].

3. Darba likums: Latvijas Republikas likums. Latvijas Vēstnesis. 105(2492), 06.07.2001. Iegūts no: https://likumi.lv/doc.php?id=26019 [sk. 13.04.2018.].

4. Latvijas Republikas Satversme: Latvijas valsts likums: pieñemts 15.02.1922. Latvijas Vēstnesis. 43, 01.07.1993. Iegūts no: https://likumi.lv/doc.php?id=57980 [sk. 13.04.2018.].

5. Par autortiesībām un blakustiesībām: Latvijas Republikas likums: zaudējis spēku. Latvijas Vēstnesis. 31, 29.05.1993. Iegūts no: https://m.likumi.lv/doc.php?id=56878 [sk. 13.04.2018.].

6. Par Latvijas Republikas likuma "Par autortiesībām un blakustiesībām" spēkā stāšanās kārtību": LR Augstākās Padomes lēmums: stājās spēkā 11.05.1993., zaudējis spēku. Latvijas Vēstnesis. 31, 29.05.1993. Iegūts no: https://likumi.lv/doc.php?id=56879 [sk. 13.04.2018.]. 
Rolands Kikors. Latvijas Republikas privāttiesību tiesu praksē laiks pāršḳirt lappusi

analogijas jēdziena un satura izpratnes attīstībā

7. Par valsts pensijām: Latvijas Republikas likums. Latvijas Vēstnesis. 182(465), 23.11.1995. Iegūts no: https://likumi.lv/doc.php?id=38048 [sk. 13.04.2018.].

8. UNIDROIT starptautiskie komerclīgumu principi. Iegūts no: https://www.unidroit.org/english/ principles/contracts/principles2010/blackletter2010-english.pdf [sk. 13.04.2018.].

\section{Tiesu prakse}

9. Balvu rajona tiesas 2013. gada 20. decembra spriedums lietā Nr. C09031913.

10. Cēsu rajona tiesas 2015. gada 26. marta spriedums lietā Nr. C11061715.

11. Cēsu rajona tiesas 2015. gada 31. augusta spriedums lietā Nr. C11090715.

12. Cēsu rajona tiesas 2016. gada 19. oktobra spriedums lietā Nr. C11092216.

13. Cēsu rajona tiesas 2017. gada 10. marta spriedums lietā Nr. C11044617.

14. Cēsu rajona tiesas 2017. gada 27. marta spriedums lietā Nr. C11045217.

15. Cēsu rajona tiesas 2017. gada 9. maija spriedums lietā Nr. C11052817.

16. Cēsu rajona tiesas 2017. gada 12. jūnija spriedums lietā Nr. C11059217.

17. Latgales apgabaltiesas Civillietu tiesas kolēgijas 2014. gada 15. maija spriedums lietā Nr. C09020413.

18. Latvijas Republikas Augstākās tiesas Civillietu departamenta 2003. gada 5. novembra spriedums lietā Nr. SKC-534. Nav publicēts.

19. Latvijas Republikas Augstākās tiesas Civillietu departamenta 2006. gada 14. jūnija lēmums lietā Nr. SKC-488.

20. Latvijas Republikas Augstākās tiesas Civillietu departamenta 2009. gada 20. maija spriedums lietā Nr. SKC-383/2009. Nav publicēts.

21. Latvijas Republikas Augstākās tiesas Civillietu departamenta 2010. gada 10. novembra spriedums lietā Nr. SKC-821. Nav publicēts.

22. Latvijas Republikas Augstākās tiesas Civillietu departamenta 2012. gada 25. janvāra spriedums lietā Nr. SKC-18/2012.

23. Latvijas Republikas Augstākās tiesas Civillietu departamenta 2015. gada 26. janvāra spriedums lietā Nr. SKC-1650/2015.

24. Latvijas Republikas Augstākās tiesas Civillietu departamenta 2017. gada 31. janvāra spriedums lietā Nr. SKC-69/2017.

25. Rēzeknes rajona tiesas 2016. gada 25. augusta spriedums lietā Nr. C26151816.

26. Rēzeknes rajona tiesas 2016. gada 31. oktobra spriedums lietā Nr. C26208916.

27. Rēzeknes tiesas 2014. gada 8. aprīla spriedums lietā Nr. C26045214

28. Rēzeknes tiesas 2014. gada 8. aprīḷa spriedums lietā Nr. C26045314.

29. Rēzeknes tiesas 2015. gada 29. aprīla spriedums lietā Nr. C26120514.

30. Rēzeknes tiesas 2015. gada 19. maija spriedums lietā Nr. C26120014.

31. Rēzeknes tiesas 2015. gada 30. septembra spriedums lietā Nr. C26105115.

32. Rēzeknes tiesas 2015. gada 11. novembra spriedums lietā Nr. C26129915.

33. Rēzeknes tiesas 2016. gada 16. februāra spriedums lietā Nr. C26130215.

34. Rēzeknes tiesas 2016. gada 25. februāra spriedums lietā Nr. C26130115.

35. Rīgas pilsētas Kurzemes rajona tiesas 2014. gada 2. jūnija spriedums lietā Nr. C28280413.

36. Satversmes tiesas 2001. gada 5. decembra spriedums lietā Nr. 2001-07-0103. Iegūts no: http:// www.satv.tiesa.gov.lv/cases/?case-filter-years=\%5B2001\%5D\&case-filter-status=\&case-filtertypes $=\&$ case-filter-result $=\&$ searchtext [sk. 04.04.2018.]. 
Rolands Kikors. Latvijas Republikas privāttiesību tiesu praksē laiks pāršḳirt lappusi analogijas jēdziena un satura izpratnes attīstībā

\section{Literatūra}

37. Bydlinski, F. 1991. Juristische Methodenlehre und Rechtsbegriff. 2., erg. Aufl. Wien.

38. Danovskis, E. Horizontal Effect of Basic Human Rights in Private Law as a Common Trend of European Integration. No: European Integration and Baltic Sea Region: Diversity and Perspectives. 2011. Riga: University of Latvia Press.

39. Esser, J. 1972. Vorverständnis und Methodenwahl in der Rechtsfindung: Rationalitätsgarantien der richterlicher Entscheidungspraxis. Frankfurt am Main: Athenäum.

40. Heller, T. 1961. Logik und Axiologie der analogen Rechtsanwendung. Berlin: de Gruyter.

41. Kalniņš, E. 2005. Privāttiesību teorija un prakse. Rìga: Tiesu namu aǵentūra.

42. Kaufmann, A. 1982. Analogie und Natur der Sache. 2. verbess. und ergänzte Aufl. Heidelberg: R. V. Decker \& C. F. Müller.

43. Kikors, R. 2017. Darbinieka likumā noteikto tiesību uz atlīdzību pēc prettiesiska uzteikuma pilnveidošana. Jurista Vārds. 45(999), 31.10.2017.

44. Larenz, K. 1991. Methodenlehre der Rechtswissenschaft. 6. Aufl. Berlin.

45. Levits, E. 2003. G̦enerālklauzulas un iestādes rīcības brīvība. Likums un Tiesības. 5. sēj., 6(46).

46. Mel̦ịisis, E. 2000. Attīstības tendences dažos tiesību teorijas un prakses jautājumos. Rīga: Latvijas Universitāte.

47. Neimanis, J. 2004. Ievads tiesībās. Rīga: zvērināts advokāts Jānis Neimanis.

48. Neimanis, J. 2006. Tiesību tālākveidošana. Rīga: Latvijas Vēstnesis.

49. Plotnieks, A. 2013. Tiesību teorija E juridiskā metode. Rīga: Izglītības solii.

50. Schmalz, D. 1992. Methodenlehre für das Juristische Studium. 3. Aufl. Baden-Baden: Nomos Verlagsgesellschaft.

51. Sinayskiy, V. 2000. Tekhnika yuridicheskoy metodologii v svyazi s obshchim ucheniyem o metodologii. Riga: RGSO. (Синайский, В. Техника юридической методологии в связи с общим учением о методологии. Рига: РГСО, 2000).

52. Slaṇḳe, G. 2012. Tiesību tālākveidošana krimināltiesībās. Jurista Vārds. 37(736), 11.09.2012.

53. Tiesību tālākveidošana. No: Juridiskās metodes pamati. 11 soḷi tiesību normu piemērošanā. 2003. E. Meḷkisis, zin. red. Rīga: Latvijas Universitāte.

54. Weinreb, L. (2005). Legal Reason: the Use of Analogy in Legal Argument. Cambridge University Press.

55. Zippelius, R. 1994. Juristische Methodenlehre. 6. Aufl. Munchen: C. H. Beck'sche Verlagsbuchhandlung. 


\title{
Globalizācijas ietekme uz līgumsoda piemērošanu
}

\author{
Zane Rinmane \\ Rìgas Stradina universitāte, \\ Juridiskā fakultāte, Latvija \\ zane.rinmane@gmail.com
}

\section{Kopsavilkums}

Rakstā sniegts ieskats līgumsoda būtības izpētē. Publikācijas mērḳis ir iepazīstināt ar pētỉjumu par līgumsoda institūtu globālā kontekstā un atklāt problēmas, kas mūsdienu tiesiskajā vidē rodas, to piemērojot. Līgumsoda institūtu pētot, par prioritāru tika izvirzìta tā samērīguma principa ievērošanas problemātika kā nacionālā, tā arī globālā mērogā. Rakstā tiek salīdzināta līgumsoda izpratne dažādās tiesību sistēmās un globalizācijas ietekme uz līgumsoda institūtu Latvijas Republikā.

Atslēgvārdi: līgumsods, iepriekš novērtēto zaudējumu atlīdzināšana.

\section{levads}

Pētot saistību tiesību attīstību, tika novērota tendence virzìties uz šo tiesību starptautisko unifikāciju un harmonizāciju. Piemēram, dạ̣a Eiropas valstu ir pārstāvēta kontinentālās Eiropas tiesību sistēma, bet citā daḷā - anglosakšu tiesību sistēma.

Līgumsods ir tiesību institūts, par kuru izpratne abās šajās tiesību sistēmās kardināli atškiras. Anglosakšu tiesībās kategoriski netiek atzīts jēdziens "līgumsods". Tiek uzskatīts, ka privāttiesības nevar saistìt ar sodīšanu, taču minētais ir pavisam normāls tiesību institūts kontinentālās Eiropas tiesībās.

Viskarstākie strīdi ir tieši par līgumsoda samērīguma jautājumiem, tādēl Latvijā likumdevējs veicis apjomīgus un būtiskus grozījumus Civillikumā līgumsoda kontekstā. Saistībā ar šiem 2013. gada 20. jūnija grozījumiem Civillikumā būtiski tika ietekmēta Latvijas tiesu prakse un liela dạ̧a Senāta tēžu zaudēja aktualitāti.

Līgumsodu samērīgums ir galvenais strīdu jautājums ne vien Latvijas, bet arī globālajās tiesībās, tomēr tas nav vienīgais. Daudz ir citu problēmjautājumu, tostarp par 
līgumsoda piemērošanu. Kā noteikt saistības vērtību beztermina līgumā? Kā noškirt saistības neizpildi vispār no saistības nepienācīgas izpildes vai neizpildīšanas noteiktā laikā? Kā noteikt galveno saistību (pamatparādu)?

Rakstā analizēti arī aktuālākie Eiropas Kopienu Tiesu prakses problēmjautājumi un izpratne par līgumsoda institūta funkcijām dažādu valstu tiesību harmonizācijas kontekstā. Pievērsta arī uzmanība tam, ka pēdējā laikā saistībā ar pētāmajiem jautājumiem judikatūra mainās arī anglosakšu tiesību saimes valstīs.

Darba mērḳis ir pētīt līgumsoda institūtu pasaulē un atklāt tā piemērošanas problēmas mūsdienu tiesiskajā vidē. Pētỉjumā tika izmantotas šādas metodes: analītiskā metode - lai analizētu tiesību normas, tiesu praksi, dažādu autoru viedokḷ us un atziņas; salīdzinošā metode - lai salīdzinātu dažādu pasaules valstu tiesību normas līgumsoda kontekstā un atspogulotu dažādu tiesību saimju izpratni par līgumsodu; vēsturiskā metode - lai sniegtu ieskatu par līgumsoda evolūciju Latvijā.

\section{Līgumsoda evolūcija Latvijā līdz mūsdienām}

Līgumsods - tāpat kā galvojums, hipotēka un rokasnauda - ir viens no visplašāk izmantotajiem saistību tiesību pastiprināšanas veidiem Latvijas Republikā. Šis tiesību institūts Latvijā pastāv jau kopš laika, kad Latvija vēl bija cariskās Krievijas sastāvdal̦a [35, 137]. Mūsdienās līgumsoda institūtu reglamentē Civillikuma (turpmāk - CL) 1716.1724. ${ }^{1}$ pants [1]. Lìgumsods ir mantisks samazinājums, ko kāda persona uzṇemas ciest, ja nepildīs vai nepienācīgi pildīs līgumsaistìbas. Līgumsodu var noteikt gan naudā, gan kādā citā vērtībā. Ikvienā līgumā var tikt paredzēts līgumsods, un pēc būtības tas pastāv kā galvenajai saistībai pakārtota saistība, jo tās izpildỉjums ir tiešā veidā atkarīgs no galvenās saistības pārkāpšanas.

Turpmāk - īss ieskats līgumsoda evolūcijā Latvijas Republikā līdz mūsdienām. Tiesību pētnieks Viktors Brīvmanis savā 1939. gada referātā "Līgumsods" norādīja, ka kreditori jau cariskās Krievijas laikā ar neproporcionāli augstiem un pieaugošiem līgumsodiem, kam nebija nekādu ierobežojumu, šo tiesību institūtu faktiski izmantoja kā peḷnas gūšanas avotu, nevis citas saistības nodrošināšanai [23, 7-8]. Acīmredzams, ka šì problēma Latvijas tiesībās bija aktuāla līdz pat Civillikuma grozījumiem 2013. gada 20. jūnijā.

Pretstatā iepriekš aprakstītajam jāpiemin padomju gadu līgumsodi privātajā sektorā, kas tolaik bija ārkārtīgi šaurs valdošās ideologijas dēḷ. Padomju laikā nebija pat iedomājams par parāda neatdošanu noteikt līgumsodu 0,5\% apmērā. Šāds līgumsods, visticamāk, tiktu kvalificēts kā bezstrādes ienākumu gūšana, par ko draudētu mantas konfiskācija [34]. Tādējādi var secināt, ka padomju varas gadi garajā līgumsoda evolūcijas periodā bija vienīgais laiks, kad nepastāvēja pārmērīgu līgumsodu problēma. Proti, tur, kur nepastāv tirgus ekonomikas institūts, nav aktuāla arī pārmērīgu līgumsodu problēma.

Pēc Latvijas Republikas neatkarības atjaunošanas, stājoties spēkā atjaunotajam Civillikumam, atkal aktuāla kḷuva arī pārmērīgu līgumsodu problēma. Pagājušā gadsimta 
90. gados tā tika risināta patēēēāju tiesībās, Patērētāju tiesību aizsardzības likumā ietverot normas par pārmērīgu līgumsodu nepieḷaušanu, proti, strīdos par pārmērīgiem līgumsodiem tiesas bieži atsaucās uz Patērētāju tiesību aizsardzības likuma normām [14]. Tomēr arī tolaik neproporcionāla līgumsoda lielums tika atstāts atklāta juridiska jēdziena formā. Ar konkrētu saturu to turpmāk ilgu laiku piepildīja tiesu prakse [33, 14-40]. Savukārt tās likumsakarīgs rezultāts bija likumdevēja 2009. gadā pieñemtie pirmie grozījumi Civillikumā attiecībā uz līgumsodu, proti, 2009. gadā Civillikumā tika ietverts jauns pants - 1724. ${ }^{1}$, kurš reglamentēja līgumsoda cietēja tiesības prasìt tiesai līgumsoda apmēra samazināšanu [1].

Tomēr jākonstatē, ka šì jaunā norma neviennozīmīgi atbilst tiesas pienākumam novērtēt pierādījumus pēc savas iekšèjās pārliecības, kas pamatota ar tiesas sēdē vispusīgi, piln̄igi un objektīvi pārbaudītiem pierādījumiem, vadoties no tiesiskās apzinnas, kas balstìta uz logiikas likumiem, zinātnes atziņām un dzīvē gūtiem novērojumiem, kā to paredz Civilprocesa likuma 97. pants [2]. Jāpievērš uzmanība arī šādam faktam: Augstākās tiesas Senāts jau līdz 2009. gadam bija secinājis, ka tiesai taisnīguma nodrošināšanas nolūkā ir tiesības vērtēt līgumsoda samērīgumu neatkarīgi no tā, vai atbildētājs ir norādījis uz līgumsoda pārmērīgi lielo apmēru. Civillikuma $1724 .{ }^{1}$ pantā tika veikti grozījumi arī 2013. gadā. Ar 2013. gada 20. jūnija grozìjumiem frāze "līgumsoda cietējs var lūgt samazināt" tika aizstāta ar "tiesa samazina", tādējādi agrākā tiesas tiesība kḷuva par tās pienākumu. Saskaṇā ar 2009. gadā Civillikumā pien̦emto $1724 .^{1}$ pantu, analizējot to gramatiski, tiesām nebija ne gluži tiesība, ne gluži pienākums pēc savas iniciatīvas samazināt pārmērīgu līgumsodu, ja pats parādnieks to tieši neprasīja. Tomēr galvenais pēc būtības šis $1724 .{ }^{1}$ panta grozījums neko nemainīja pārmērīgu līgumsodu problēmas risināšanā. Proti, jaunais regulējums nedeva vēlamo rezultātu, jo īpaši n,emot vērā, ka Latvijā saistībā ar pārmērīgu līgumsodu samazināšanas praksi jau diezgan ilgstoši pastāv šāda Eiropas Savienības Tiesas nostādnēm atbilstoša Senāta judikatūra.

Līgumsoda kontekstā īpaši jāuzsver Civillikuma 2013. gada 20. jūnija apjomīgie grozijumi, kas tika veikti situācijas eskalācijas dẹl, ko savukārt izraisīja strauji plaukstošais ātro kredītu izsniegšanas bizness un parādu piedziššnas organizāciju skaita palielinājums.

Galvenās pārmaiṇas līgumsoda institūtā kopš minētajiem grozijjumiem ir šādas:

- līgumsoda iedalïjums pēc tã veida (CL 1716. pants);

- līgumsoda aprobežojums procentuāli pieaugošiem maksājumiem (CL 1716. pants);

- ierobežojums prasīt gan likumiskos procentus, gan līgumsodu pilnā apmērā (CL 1722. pants);

- samērīguma princips (CL 1717. pants);

- tiesas pienākums samazināt līgumsodu (CL 1724. ${ }^{1}$ pants);

- atšķirīga maksājumu ieskaitǐšanas kārtība (CL 1843. pants).

Nav šaubu, ka līgumsoda evolūciju Latvijā ir ietekmējusi globalizācija, kas saistās ar geogrāfisko robežu izzušanu, tādējādi saasinot problēmjautājumus, tostarp par saistību izpildi un līgumsoda piemērošanu. 


\section{Spēkā esošo harmonizācijas aktu ietekme uz līgumsodu}

Pasaulē sastopamas vairākas tiesību sistēmas. Daḷā valstu ir pārstāvēta kontinentālās Eiropas tiesību sistēma, bet citā - anglosakšu tiesību sistēma. Lìgumsoda institūta izpratne abās šajās tiesību sistēmās kardināli atšķiras. Anglosakšu tiesībās kategoriski netiek atzìts jēdziens "līgumsods", jo privāttiesības netiek saistìtas ar sodīšanu. Turpretī kontinentālās Eiropas tiesībās līgumsods ir pavisam normāls tiesību institūts. Turpmāk tiks aplūkoti atsevišḳi saistību tiesību harmonizācijas akti, kam ir ietekme uz līgumsoda izpratni un piemērošanu. Izstrādātos līgumtiesību unificēšanas dokumentus var iedalīt: dokumenti ar juridisko spēku - konvencijas, starptautiskie līgumi, regulas, direktīvas jeb hard law - un dažādi doktrināri dokumenti, rezolūcijas, proti, ieteikuma tiesības jeb soft law [35, 19-26].

Vistradicionālākā metode starptautisko privāttiesību saskaņošanā ir tiesību normu unificēšana, izmantojot konvenciju un starptautisko līgumu, kā arī Eiropas Savienības dokumentu (regulu, direktīvu) saistošo spēku.

Pirmkārt, jāapskata Apvienoto Nāciju Organizācijas 1980. gada 11. aprīḷa Konvencija par starptautiskajiem preču pirkuma un pārdevuma līgumiem [13]. Konvencija līgumslēdzēju pusēm reglamentē tādu tiesiskās aizsardzỉbas līdzekli kā zaudējumu atlīdzināšanu.

Konvencijas 74. pantā tiek definēts, kas tieši uzskatāms par zaudējumiem:

“Zaudējumi, kuri rodas, pusei neievērojot līgumu, sastāv no summas, kura ir vienāda ar tiem zaudējumiem, ieskaitot neiegūto labumu, kuri radušies, otrajai pusei pārkāpjot līgumu. Tādi zaudējumi nedrīkst pārsniegt zaudējumus, kurus līgumu pārkāpusī puse līguma slēgšanas brīdī paredzējusi vai kurus tai vajadzēja paredzēt kā iespējamās sekas līguma pārkāpumam, n,emot vērā apstākḷus, par kuriem viṇa tajā laikā zināja vai par kuriem viṇai vajadzēja zināt." [13]

No šìs definīcijas izriet, ka zaudējumi ir ne vien tiešie zaudējumi, bet arī neiegūtais labums, kas var būt līguma pārkāpuma rezultāts. Tomēr pastāv arī piebilde, ka neiegūtajam labumam līguma slēgšanas brīdī vajadzēja būt tieši un precīzi paredzētam. Tādējādi ir konstatējams, ka Konvencijā iekḷauts anglosakšu tiesībām raksturīgais iepriekš novērtēto zaudējumu atlīdzināšanas (liquidated damages) institūts. Proti, jau līguma slēgšanas brīdī pusēm ir skaidri zināmi par zaudējumiem atlīdzināmās materiālās vērtïbas griesti.

Otrkārt, atsevišḳi jāizceḷ Direktīva 2011/7/ES par maksājumu kavējumu novēršanu komercdarijumos [7]. Pārṇemot konkrētās direktīvas normas, Civillikumā tika ieviests Latvijā jauns tiesību institūts "iepriekš novērtētie zaudējumi" (CL 1668. ${ }^{1}$ pants), kas pēc būtības ir tas pats "līgumsoda" institūts Civillikuma 1716. panta izpratnē. Latvijas tiesībās nevajadzētu ieviest anglosakšu tiesībām raksturīgu institūtu, ja iespējams vajadzību izteikt ar jau pastāvošo, t. i., kontinentālās Eiropas tiesībām raksturīgo līgumsodu.

Treškārt, līgumsoda kontekstā jāpiemin Eiropas Padomes 1993. gada 5. aprīḷa Direktīva 93/13/EEK par negodīgiem noteikumiem patērētāju līgumos [5]. Konkrētāk, - 
Direktīvas par negodīgiem līguma noteikumiem 3. panta trešās daḷas indikatīvā pielikuma 1. e punktu: "[..] pieprasīt patērētājam, kurš nespēj izpildìt savas saistības, maksāt neproporcionāli lielu kompensāciju.” Direktīvas par negodīgiem līguma noteikumiem 3. panta trešā punkta (pielikuma 1. e punkts attiecībā uz neproporcionālu kompensāciju) prasības iestrādātas Patērētāju tiesību aizsardzības likuma 6. panta trešās daḷas ceturtajā punktā [14].

Kopš 2011. gada 1. janvāra ar šo pantu noteikts, ka par netaisnīgiem līguma noteikumiem ir uzskatāmi tādi noteikumi, "kas uzliek patērētājam, kurš neizpilda vai nepienācīgi izpilda līgumsaistības, neproporcionāli lielu līgumsodu vai citu kompensāciju par līgumsaistību neizpildi vai nepienācīgu izpildi salīdzinājumā ar līgumsaistību neizpildīšanas vai nepienācīgas izpildīšanas radīto zaudējumu vai ṇemot vērā citus apstākḷus" [14]. Iepriekšèjā redakcija bija šāda: "[..] uzliek patērētājam, kurš neizpilda līgumsaistības, neproporcionāli lielu līgumsodu." Ši "cita kompensācija par saistību neizpildi", ko likumdevējs faktiski pielīdzinājis līgumsodam, ir tie paši nokavējuma procenti un jebkādi citi kompensācijas veidi. Raugoties uz līgumsodu patērētāju tiesību izpratnē, nav būtiski, ka šis tiesību institūts tiktu saukts tieši šādā vārdā, proti, par līgumsodu. Kā redzams, regulējums attiecas ne vien uz līgumsodu, bet arī uz jebkādām citām kompensācijām, tostarp nokavējuma procentiem.

Patērētāju tiesību aizsardzības likuma jaunajā redakcijā tiek ṇemti vērā arī līgumsaistību neizpildīšanas vai nepienācīgas izpildīšanas radītie zaudējumi. Tas l̦auj secināt, ka patērētāju tiesības ierobežo līgumsoda sodī̌anas funkciju, nedaudz tuvinoties anglosakšu tiesībām raksturīgajai minētā tiesību institūta izpratnei.

Pētot, kā Eiropas Kopienu Tiesa (turpmāk - EKT) raugās uz līgumsoda institūtu Direktīvas par negodīgiem līguma noteikumiem kontekstā, var secināt, ka līgumsods kā netaisnīgs līguma elements visbiežāk sastopams tieši šìs direktīvas izpratnē, piemēram, EKT lietā C-488/11 [21] uz prejudiciālu jautājumu par Direktīvas par negodīgiem līguma noteikumiem 6. panta 1. punkta interpretāciju. Tiesvedībā tika nodots iesniedzējtiesas lūgums par ìres līguma parāda, līgumisko procentu un soda naudas samaksu atbilstoši īres līgumā paredzētajam.

Direktīvas 6. panta 1. punktā noteikts:

"Dalïbvalstis nosaka, ka negodīgi noteikumi, kas izmantoti pārdevēja vai piegādātāja ar patērētāju noslēgtā līgumā, atbilstoši savas valsts tiesību aktiem nav saistoši patērētājam un ka lïgums pie tādiem pašiem noteikumiem turpina pusēm būt saistošs, ja tas var pastāvēt bez negodīgajiem noteikumiem." [5]

Ar šo jautājumu iesniedzējtiesa vēlējās noskaidrot, vai direktīvas 6. pants ir interpretējams tādējādi, ka atbilstoši tam valsts tiesa, kas konstatējusi noteikuma par līgumsodu negodīgumu, tā vietā, lai šo noteikumu nepiemērotu, var samazināt tajā paredzētā līgumsoda apmēru, kā tas atḷauts atbilstoši valsts tiesībām un kā to ir lūdzis patērētājs. EKT savā spriedumā secināja, ka starp profesionāli un patērētāju noslēgtais līgums "pie tādiem pašiem noteikumiem" turpina būt pusēm saistošs, ja tas var pastāvēt "bez negodīgajiem noteikumiem". Vienīgi valstu tiesām ir pienākums novērst negodīga līguma 
noteikuma piemērošanu, lai patērētājam tas nebūtu saistošs, bet tām nav tiesību korigèt tā saturu. Līgumam principā ir jāturpina pastāvēt bez kādiem citiem grozìjumiem, izṇemot negodīgu noteikumu svìtrošanu. Proti, atbilstoši direktīvas 6. panta 1. punktam, ja valstu tiesas konstatē starp profesionāli un patērētāju noslēgta līguma noteikuma par līgumsodu negodīgumu, tās nedrīkst samazināt patērētājam piemērojamā līgumsoda apmēru, tā vietā tiesas attiecīgo līguma noteikumu nepiemēro vispār. Turklāt EKT īpašu uzsvaru liek uz to, ka pašu līgumsoda samērīguma jautājumu Direktīvas par negodīgiem līguma noteikumiem neregulē, to izskata un vērtē nacionālās tiesas pēc savas iniciatīvas.

Ceturtkārt, jāatzīmē arī Eiropas Parlamenta un Padomes 2008. gada 23. aprị̣a Direktīva 2008/48/EK par patēriņa kredītlīgumiem un ar ko atcel Direktīvu 87/102/EEK [6]. Šì direktīva līgumsoda kontekstā jāmin, jo tās atsevišķos pantos noteikts, kāda informācija patērētājam jāsniedz pirms līguma noslēgšanas (5. panta pirmā punkta l. apakšpunktā un 6. panta pirmā punkta i apakšpunktā): "[..] procentus maksājumu kavējumu gadījumā un procedūru to korigéšsanai, un - attiecīgā gadījumā - maksu par saistību nepildīšanu." Tātad šajā direktīvā netiek precizēts, vai līgumsods, kas izriet no minētajiem pantiem, būtu drīzāk zaudējumu atlīdzība vai sods par līguma nepienācīgu izpildī̌anu, vien tajā norādīts, ka informācija par līgumsoda apjomu ir viens no obligātajiem elementiem patēriņa kredìtlīgumos, turklāt to piel̦aujams noteikt gan procentu izteiksmē, gan nemainīgā, konkrētā summā, tādējādi sasaucoties ar Latvijas Civillikuma reglamentēto līgumsoda institūtu.

Pie unifikācijas instrumentiem pieskaita arī dažādus parauglikumus (model law), principus, rekomendācijas un vadlīnijas. Daudzi komersanti, kas darbojas Eiropas Savienības iekšējā tirgū, mūsdienās ievēro Eiropas līgumtiesību principus [30, 359-461]. Šo principu izstrādātāji n,ēmuši vērā galvenokārt Eiropas Savienības dalībvalstu tiesību normas, kā arī citu valstu un starptautiskās tiesības, piemēram, ASV Vienoto tirdzniecības kodeksu [19], Kanādas tiesību idejas, 1980. gada Vīnes konvenciju par starptautiskajiem preču pirkuma un pārdevuma līgumiem [13].

Pie dokumentiem, kuros sistēmiski apvienoti līgumtiesību principi, jāmin arī neatkarīgās starpvalstu organizācijas - Starptautisko privāttiesību institūta (UNIDROIT The International Institute for the Unification of Private Law's) - starptautiskie komerclïgumu principi [36]. UNIDROIT principu mērķis ir regulēt tirdzniecības tiesības visā pasaulē, ne tikai Eiropas Savienībā (atšḳirībā no Eiropas līgumtiesību principiem). UNIDROIT līgumtiesību principi tiek piemēroti arī ārpus Eiropas Savienības, piemēram, ASV. Arī UNIDROIT principiem ir rekomendējošs raksturs, un tie var tikt piemēroti, ja līdzèji par tiem vienojas [24].

Svarīgi ir ne tikai jau nosauktie doktrinārie dokumenti, bet arī Kopējais model̦a projekts (DCFR - Draft Common Frame of Reference jeb Saistibu tiesibu kopëjais modelis) [3]. Tas ir dokuments, kurā apkopoti Eiropas privāttiesību principi, definīcijas un noteikumi. Kopējais modeḷa projekts, pēc tā izstrādātāju domām, varētu kalpot kā paraugs dalībvalstu likumdevējiem. Taču arī šis dokuments nav Eiropas Savienības normatīvs dokuments, un tā trūkums ir milzīgais apjoms, kas droši vien apgrūtinās dalībvalstu likumdevēju iespējas izmantot šo apkopojumu. 
Līgumsoda kontekstā jāakcentē Eiropas Padomes Ministru komitejas 1978. gada 20. janvārī pieṇemtā rezolūcija Nr. (78)3 “Par soda klauzulu civiltiesībās” [31]. Šĩ rezolūcija ir nozīmīga Latvijas civiltiesībās jaunas pieejas dēl līgumsoda aprēḳināšanā, kas izriet no Augstākās tiesas Senāta 2005. gada 26. janvāra sprieduma lietā Nr. SKC-48 par aizdevuma un līgumsoda piedziṇu. Ar Senāta argumentu, ka, "balstoties uz Eiropas Kopienu Tiesas judikatūru, Eiropas Padomes Ministru komitejas rekomendācijai "Par soda klauzulu civiltiesībās" ir netieša un horizontāla iedarbība" [22], turpmāk tiesas visai bieži savā argumentācijā atsaucās uz minēto rezolūciju Nr. (78)3.

Aplūkojot šeit pieminētos aktus - gan ar juridisko spēku apveltìtos, gan dokumentus ar ieteikuma raksturu, var secināt, ka līgumsoda institūts galvenokārt tiek skatìts nevis kā soda mērs, bet gan kā iepriekš novērtēti (vai novērtējami) atlīdzināmie zaudējumi. Aplūkoto tiesību harmonizācijas aktu regulējums neaizliedz par saistību nepienācīgu izpildi piemērot sodoša rakstura līgumsodu, tomēr šis regulējums vairāk līdzinās anglosakšu tiesību saimei raksturīgajam, t. i., izprotot līgumsodu vien kā zaudējumu atlīdzināšanu, un ir pret sodīšanu privāttiesību jomā vispār. Lai skaidrāk izprastu atškiriību starp šiem šķietami līdzīgajiem tiesību institūtiem, jāsalīdzina iepriekš novērtēto zaudējumu atlīdzināšanas un līgumsoda institūts.

\section{Divu klauzulu - iepriekš novērtēto zaudējumu atlīdzināšanas un līgumsoda kā soda - salīdzinājums}

Pastāv būtiska atšḳirība starp dažādās tiesību saimēs atspogụ̣oto līgumsoda institūtu. Fundamentāla atšḳirība par tā izpratni ir kontinentālās Eiropas tiesību sistēmā un anglosakšu tiesību sistēmā. Arī mūsdienās tiesību zinātnieki nespēj rast kompromisu jautājumos par atbildību līgumattiecībās. Daḷa uzskata, ka līgumiskās attiecībās soda sankcijas ir attaisnojamas, savukārt citu nostāja pret tām ir visnotaḷ negatīva.

Vairākumā Eiropas valstu ir pārstāvēta kontinentālās Eiropas tiesību saime. Tā ir Baltijas valstīs, Vācijā, Francijā, Austrijā, Šveicē, Itālijā, Spānijā, Grieḳijā, Portugālē, Beḷgijāā, Nìderlandē, Luksemburgā u. c. Ārpus Eiropas šìs tiesības izplatījušās Tuvo Austrumu valstīs, Dienvidkorejā, Taivānā, Taizemē (saistību tiesību jomā tās tiek dēvētas par "Civilkodeksu valstīm”). Savukārt anglosakšu tiesību saime ir pārstāvēta Anglijā, Velsā, İrijā, Ziemelīirijā, savukārt ārpus Eiropas - ASV (izṇemot Luiziānu), Kanādā (izṇemot Kvebeku), Austrālijā, Jaunzēlandē, Lielbritānijas bijušajās kolonijās u. c.

Pasaulē līgumsods tiek saukts dažādi, piemēram, penalty clause, punitive, exemplary damages, punitive damages - tie visi ir apzīmējumi atrunai par soda naudas izmaksu; turpretī liquidated damages, stipulated payment, stipulated sum, agreed - remedy provision apzīmē iepriekš novērtētu un atrunātu zaudējumus atlīdzinošu summu.

ASV pastāv tikai iepriekš novērtēto zaudējumu atlīdzināšanas institūts, kas paredzēts zaudējumu atlīdzināšanai, un tas tiek piemērots gadījumā, ja tiesa konstatē, ka ar līguma pārkāpumu radītais zaudējums ir grūti aplēšams, taču iepriekš līgumā norunātā 
summa zaudējuma atlīdzināšanai ir samērīga kompensācija gan par esošajiem, gan nākotnē paredzamiem zaudējumiem. Iepriekš novērtēto zaudējumu atlīdzināšanas institūta mērḳis ASV ir grūti pierādāmu un izmērāmu zaudējumu atlīdzināšana. Ja tomēr tiesa konstatē, ka iepriekš norunāto zaudējumu atruna ir nesamērīgi augsta pret zaudējumiem, kas izriet no līguma pārkāpuma, šì atruna tiek uzskatìta par spēkā neesošu un pusei, kas cietusi no līguma pārkāpuma, ir tiesības prasìt tikai atlīdzību par faktiskajiem zaudējumiem $[27,1-7]$.

Iepriekš novērtēto zaudējumu atlīdzināšanas klauzulu izskatî̌ana ASV jurisdikcijā ir atškirīga, tomēr parasti tiesas, skatot, vai šì klauzula tiek izpildìta, vērtē divus aspektus. Viens no šiem aspektiem ir nenoteiktības elements, proti, vai ar līguma pārkāpumu radīto kaitējumu ir grūti noteikt. Otrs - pamatotība, proti, vai iepriekš novērtēto zaudējumu atlīdzināšanas summa ir pamatota proporcionāli faktiskajiem vai nākotnē sagaidāmajiem zaudējumiem, kas izriet no līguma pārkāpuma. Ja tā nav, tad minētais tiesību institūts tiek uzskatīts par sodu, kas ir prettiesisks ASV privāttiesību jomā, un tādējādi iepriekš novērtēto zaudējumu atlīdzināšanas klauzula nav piemērojama [29, 656-659].

Citās valstīs, kurās ir paražu tiesības, piemēram, Lielbritānijā, İrijā, Austrālijā un Kanādā, ir līdzīgi noteikumi saistībā ar iepriekš novērtēto zaudējumu atlīdzināšanas institūtu, kuru ir aizliegts izmantot sodīšanas nolūkā. Iznēemums ir Indijas līgumtiesības, kurās Līgumu likums nenošķir iepriekš novērtēto zaudējumu atlīdzību un līgumsodu. Lìgumsodu šeit aț̣auts piedzìt no līgumu pārkāpušās puses pat gadījumā, ja tā funkcija ir sodìt līguma pārkāpēju [10].

Ja zaudējumu atlīdzināšanas institūts balstìts uz nosacỉjumu, ka līgumsaistību neizpildes vai nepienācīgas izpildes gadījumā ir nodarīi faktiski un pierādāmi zaudējumi, kas jāatlīdzina, tad, lai îstenotu soda klauzulu, nav nepieciešams zaudējumu pierādīšanas fakts.

Pētot dažādu valstu, kurās atzīst līgumsodu kā soda klauzulu, civilkodeksus, var secināt, ka tajos atspogulotas Eiropas Padomes Ministru komitejas 1978. gada 20. janvāra rezolūcijas (78)3 "Par soda klauzulu civiltiesībās" rekomendācijas [27, 1-7]. Piemēram, Igaunijas Saistỉbu tiesību 162. pantā [18], Vācijas Civilkodeksa 343. pantā [9] un Nīderlandes Civilkodeksa 6:94. panta 1. daḷā [17] ḷauts tiesām pèc puses lūguma samazināt līgumsodu, ja tas ir pārmērīgs, un Lietuvas Civillikumā - arī gadījumā, ja saistība jau daḹèji izpildīta [12]. Līgumsodu samazināt samērā ar pienākuma neizpildes sekām ḷauts arī atbilstīgi Francijas Civilkodeksa 1152. pantam [16].

Savukārt Itālijā saistību tiesībās tiek atzīta gan zaudējumu atlīdzināšana, gan soda klauzula, taču tās pastāv vien tiesību doktrīnā, nevis Civilkodeksā. Itālijas saistību tiesībās līgumsods kā soda sankcija tiek piel̦auts, taču tiesa to var samazināt, ja tas ir pārmērīgs vai ja puse izpildijjusi galveno saistību [28, 309-326].

Spānijas Civilkodeksa 1154. pantā noteikts, ka tiesnesis objektīvi var mainīt līgumsoda lielumu, taču tikai gadījumā, ja parādnieks savas saistības ir pildījis (daḷēji vai neregulāri) [15]. Spānijas Civilkodekss ir viens no retajiem, kas noškị, vai līgumu pārkāpusi juridiska vai fiziska persona. Arī šis apstāklis tiesā, izskatot līgumsoda samazināšanas 
pamatu, tiek nnemts vērā. Jāpiemin, ka Spānija ir viena no retajām valstīm, kas nav veikusi grozījumus Civilkodeksā, l̦aujot tiesai samazināt līgumsodu vien tādēl, ka tas ir pārmērīgs $[25,100-103]$.

Spānijas doktrīnā, līdzīgi kā Francijas doktrīnā, tiek diskutēts par iespēju ieviest fiksētu, iepriekš norunātu summu par līguma laušanu neatkarīgi no tā, vai tā būtu zaudējumu atlīdzināšana vai līgumsods. Atškirinibā no Latvijas doktrīnas šajās diskusijās tiek minēta nesamērīgi maza iepriekš norunātā summa par līguma laušanu, proti, Francijas un Spānijas praksē acīmredzot biežāk sastopama problēma, ka līgumā, nosakot pārāk mazu līgumsodu, nolīgtā neizpildes gadỉjumā zaudējumus cieš tieši kreditors [25, 100-103]. Un šajā sakarā, atsaucot atmiṇā Latvijas Civillikuma 2013. gada 20. jūnija grozījumus, iespējams, jaunajā regulējumā tiks noteikts, ka atsevišķos gadījumos kreditors var nokḷūt neizdevīgā ekonomiskā situācijā, ja parādniekam par nepienācīgu līguma izpildi jāmaksā maksimums - $10 \%$ no pamatparāda vai galvenās summas, lai arī kreditora zaudējumi no šādas nepienācīgas izpildes varētu krietni pārsniegt šo 10 \% līgumsoda slieksni. Piemēram varētu minēt būvniecības jomu.

Šveices tiesiskais regulējums ir visai līdzīgs Vācijas un Nĩderlandes regulējumam, kas tiesai ḷauj samazināt līgumsodu, ja tas ir acīmredzami pārmērīgs. Šveices Civilkodeksā reglamentēta tiesas tiesība samazināt līgumsodu, ja tas ir pārmērīgs [25, 100-103].

Skandināvijas valstu - Dānijas, Norvēgijas un Zviedrijas - tiesiskais regulējums l̦auj tiesām mainīt līgumsoda lielumu, ja tās uzskata to par nepamatotu, vai pat līgumsodu pilnībā atcelt [27, 1-7]. Piemēram, Zviedrijas Tirdzniecības kodeksā tiek diferencētas gan līguma slēdzēja puses - vājāko un stiprāko līdzēju - līgumsoda piemērošanas jautājumos, gan, aizsargājot kādu pusi, tiek ņemti vērā īpaši apsvērumi. Tādējādi saskatāma līdzība ar Igaunijas, Vācijas un Spānijas tiesību normām, kurās ṇemts vērā pušu ekonomiskais stāvoklis, likumīgās intereses un tiesiskais statuss.

Arī Beḷgijas Augstākā tiesa ir noteikusi, ka iepriekš norunātais maksājums zaudējumu atlīdzināšanai, kurš bijis spēkā, slēdzot līgumu, bet laika gaitā zaudējis savu zaudējumu atlīdzināšanas funkciju, kḷūstot par sodīšanas līdzekli, ir atceḷams. Arī citos gadījumos iepriekš līgumā norunātais maksājums ir samazināms, ja tas uzskatāms par acīmredzami nesamērīgu, salīdzinot ar saistību neizpildes sekām [30, 456].

Citas valstis, kurās ir civillikums un kuras ir ārpus Eiropas, arī ir pārṇēmušas līdzīgu pieeju līgumsodu samērīguma regulēšanā. Kinnas Tautas Republikas Līgumtiesību likumā (turpmāk - K,TR Līgumtiesību likums) paredzēti trīs veidu tiesiskās aizsardzības līdzekḷi - līguma turpmāka izpildīšana neatkarīgi no zaudējumu atlīdzināšanas, zaudējumu atlīdzināšana un līgumsods. KTRR Līgumtiesību likuma 114. pantā noteikts, ka līguma slēdzējas puses var vienoties par noteiktu summu, ko maksā līgumu pārkāpusī puse. Tāpat puses var vienoties par zaudējumu atlīdzỉbu, ko maksā otrai pusei līgumu pārkāpusī puse, n,emot vērā pārkāpuma smagumu. Puses var noteikt arī metodi, kā aprēkināt atlīdzību par zaudējumiem, kas radušies līguma pārkāpuma dēḷ. Turklāt likumā noteikts: ja iepriekš ar līgumu noteiktā summa ir mazāka par zaudējumiem, kas izriet no līguma pārkāpuma, cietusī puse var sniegt Tautas tiesā vai škīiējtiesā lūgumrakstu ar 
lūgumu palielināt līgumsoda lielumu. Attiecīgi, ja līgumā noteiktais līgumsods pārsniedz zaudējumus, kas izriet no līguma pārkāpuma, Tautas tiesa vai šḳirējtiesa ir tiesīga to samazināt. Ja puses līgumā ir noteikušas līgumsodu par novēlotu līgumsaistību izpildi, tai pusei, kas pārkāpusi līgumu, ir ne vien pienākums samaksāt līgumsodu, bet arī izpildīt līgumsaistības [4]. Līguma turpmāka izpildījuma pieprasīšana nozīmē, ka cietusī puse otrai pusei var prasìt līguma turpmāku izpildī̌sanu, ja izpildīšana joprojām ir iespējama. Tādējādi šāda prasība ir savā ziṇā pielīdzināma sankcijai, jo tā vairs nav tas pats, kas brīvprātīgs izpildījums. Šādas nepārtrauktas darbības mērḳis ir konkrētas darbības vai faktisko darbību rezultāts. Šāda nepārtraukta darbība ir traktējama kā juridisks pienākums, proti, sankcija. Maksājumu saistībās ir prasība obligāti izpildīt līgumu [26, 12].

Līdzīgi kā anglosakšu tiesību saimi pārstāvošajās valstīs, arī Ǩinā īpaši netiek atzīta līgumsoda sodīšanas funkciju. Atškiriībā no faktisko zaudējumu atlīdzināšanas institūta (valstīs, kurās ir paražu tiesības, pazistama kā damages) K,TR Līgumtiesību likums reglamentē arī tiesību institūtu, kura galvenā pazīme ir paredzamība (iepriekš aprēḳinātie zaudējumi, potenciālie zaudējumi, kas rodas laika gaitā, pakāpeniski - liquidated damages, kā valstīs, kurās ir paražu tiesības). Lìguma slēdzēja puses līgumā var brīvi vienoties par šo abu lïgumsodu veidu lielumu, bet tas ar likumu ir aprobežots ar zaudējumu un iespējamo zaudējumu lielumu, kas radies nepienācīgas līguma izpildes dēḷ. Nav spēkā tādi līgumsodi (ĶTR Līgumtiesību likumā saukti par zaudējumu atlīdzināšanu), kam ir tikai sodīšanas funkcija.

Ir visai sarežgìiti rast vienādu līgumsoda regulējumu Eiropas (un ne tikai) valstīs. Atškiras pat to piemērošanas pamatmērḳi - zaudējumu atlīdzināšana vai sods. Vairāku valstu tiesas nekad nav vērtējušas, vai līgumā noteiktais līgumsods vērtējams kā sods. Proti, tiesas nenošḳir zaudējumu atlīdzināšanas institūtu no līgumsoda ar sodīšanas funkciju institūta. Tās vērtē vien to, vai piemērošana ir tiesiska un vai sods nav pārmērīgs, salīdzinot ar zaudējumiem līguma neizpildes dēḷ. Šāda pieeja ir visai tuva anglosakšu pieejai līgumsodu samērīguma regulēšanā.

Salīdzinot zaudējumu atlīdzināšanas un līgumsoda (kā sankcijas) izpausmes, var secināt, ka nevienā no pētāmajām valstīm netiek noliegta zaudējumu atlīdzināšanas klauzula (gan iepriekš novērtētā, gan faktiskā). Tomēr tiesas vērš uzmanību arī uz šī tiesību institūta samērīgumu attiecībā pret zaudējumiem, kas ir vai var rasties līguma nepienācīgas izpildes dēḷ. Savukārt līgumsodu kā sankciju neatzīst nevienā anglosakšu tiesību saimes jeb precedentu tiesību valstī, tāpat kā dạ̦ā t. s. civilkodeksu valstu. Joprojām zinātnieki diskutē par un pret līgumsodu kā saistību pastiprināšanas līdzekli, kā draudu pret nelabvēlīgām sekām līguma pārkāpuma gadījumā. Bieži vien tiesību zinātnieki, kas nostājas pret līgumsodu kā sodīšanas instrumentu, norāda, ka tā noteikšana līgumā var veicināt nevis līguma izpildi, bet, gluži pretēji - tā neizpildi, ja līguma izpildī̌̌anas pienākums ir smagāks par līgumsoda samaksu [29, 659-661]. Šādām bažām ir pamats, jo īpaši ṇemot vērā, ka Civillikumā tiek ierobežots līgumsoda lielums. Tas var provocēt situācijas, kurās līguma slēdzējam ir vienkāršāk samaksāt līgumsodu par saistību neizpildi, atstājot otru līguma slēdzēju ekonomiski neizdevīgā situācijā. Ķinā likumiskā spēkā ir viens tiesiskās aizsardzības līdzeklis, kas varētu atrisināt šo situāciju, - līguma turpmākas 
izpildīšanas pieprasī̌̌ana, ja vien tas ir iespējams. Tomēr citviet pasaulē šādu tiesiskās aizsardzības līdzekḷ nav. Vairāki tiesību zinātnieki uzsver, ka bieži vien ir tā, ka iepriekš novērtētie zaudējumi nav pietiekami, lai segtu visus reālos un nākotnē paredzamos zaudējumus pusei, kura cietusi no līguma nepienācīgas izpildes.

Aplūkojot dažādu valstu praksi līgumsodu piemērošanā un n̦emot vērā Civillikuma jauno līgumsoda regulējumu, saistībā ar līgumsoda aprobežošanu Latvijas saistību tiesībās var saskatīt vairākus problēmjautājumus.

1. Jautājums par saistības vērtības noteikšanu. Piemērs: beztermiṇa līgums ar periodiskiem maksājumiem. Kā noteikt līguma vērtību, no kuras jāizriet līgumsodam?

2. Līgumsoda samērīguma jautājums. Piemērs: līgumsods par saistību neizpildi termiņā ir aprobežots ar 10\% no pamatparāda vai galvenās saistỉbas, taču likumā nav noteikts, par cik ilgu kavējumu kreditors var prasit līgumsodu pilnā apmērā, proti, vai visus $10 \%$ no līguma summas kreditors drīkst prasīt arī par vienas dienas kavējumu. Vai šādos apstākḷos līgumsods būs samērīgs?

3. Kas jāsaprot ar jēdzienu "galvenā saistība"? Piemērs: par līgumu, kas noslēgts uz gadu, pasūtītājs par pakalpojumu maksā mēnesi uz priekšu. Gadỉjumā, ja pasūtìtājs kavē maksājumu, kas būtu uzskatāms par galveno saistību - visa atlikusī, nesamaksātā summa vai ikmēneša maksājuma summa?

Otrs problēmjautājumu loks - kā nošḳirt saistību neizpildi vispār no saistību nepienācīgas izpildes vai neizpildes noteiktā laikā? Lai paskaidrotu, kāpēc šo faktoru nodalīšanā var rasties grūtības, ilustrācijai noderēs daži piemēri.

1. Lìgums starp pusēm tiek noslēgts uz diviem gadiem. Lìgumā paredzētas vienas puses vienpusējas tiesības izbeigt līgumu pirms termiṇa, samaksājot par to vienreizēju līgumsodu. Mēnesi pēc līguma noslēgšanas viena puse vienpusēji lauž līgumu. Vai šajā situācijā ir saistību neizpilde vispār vai nepienācīga izpilde (t. i., neizpildīšana īstajā laikā)?

2. Starp pusēm tiek slēgts līgums par terminētu preces piegādi. Prece tiek piegādāta termiṇā, taču tā ir ar trūkumiem. Kā saistība būtu traktējama šajā gadījumā - kā neizpildīta vispār vai nepienācīgi izpildīta termiṇā?

N̦emot vērā iepriekš aplū kotos problēmjautājumus, varētu šḳist, ka globālā mērogā līgumsods tiek pietuvināts anglosakšu tiesību saimes valstīm raksturīgai iepriekš novērtēto zaudējumu atlīdzināšanai, tomēr netrūkst piemēru, ka arī anglosakšu tiesību saimes valstī Lielbritānijā skatījums uz šo tiesību institūtu nav tik viennozīmīgs. Piemēram, jāieskatās sen - 1914. gadā - Apvienotās Karalistes Lordu palātā izskatītā lietā Dunlop Pneumatic Tyre Company Limited $v$ The New Garage and Motor Company Limited [20], kas pēc simts gadiem kḷuvusi aktuāla Anglijas un Velsas Augstākajā tiesā iepriekš novērtēto zaudējumu atlīdzināšanas klauzulas un soda klauzulas kontekstā. Dunlop Tyres noslēdza līgumu ar New Garage Company par preču (riepu pārsegu un cauruḷu) piegādi. Ar šo līgumu New Garage Company apṇēmās nepārdot minētās preces saviem klientiem par zemāku cenu, nekā ražotājs noteicis. Līguma 5. punktā noteikts, ka New Garage Company apṇemas par līguma pārkāpšanu maksāt Dunlop Tyres piecas Lielbritānijas 
sterliṇu mārcinas par katru riepas pārsegu un cauruli, kas tiktu pārdota, pārkāpjot līgumu. Vēlāk Dunlop Tyres konstatēja, ka New Garage Company pārdevusi riepu pārsegus un caurules, kas nebija saskaṇā ar aktuālo Dunlop Tyres noteikto cenrādi, tādējādi Dunlop Tyres cēla prasību tiesā, prasot zaudējumu atlīdzināšanu no New Garage Company.

Tiesā tika vērtēts, vai piecas mārciṇas ir traktējamas kā iepriekš novērtēto zaudējumu atlīdzinājums vai līgumsods, t. i., kā soda nauda (sankcija). Zemākās instances tiesa lēma, ka piecas mārcinas jātraktē kā zaudējumu atlīdzinājuma summa un tā ir piedzenama no New Garage Company. Turpretim apelācijas instances tiesa sprieda, ka minētā summa ir drīzāk soda nauda, nevis iepriekš novērtētie zaudējumi, kas varētu rasties nākotnē negūtu ienākumu veidā, tādēl apelācijas instances tiesa lēma, ka Dunlop Tyres var saṇemt lïdzekḷus tikai par faktiskajiem zaudējumiem. Dunlop Tyres šo lēmumu pārsūdzēja, un lieta nonāca Augstākajā tiesā. Lordu palāta, izskatot lietu, saskārās ar jautājumu par faktiskajiem zaudējumiem un iepriekš novērtētajiem zaudējumiem, kas saistāmi ar iespējamiem nākotnes zaudējumiem, tāpat ar jautājumu, vai līgumā noteiktā summa - piecas mārciņas - ir drīzāk iepriekš novērtēti zaudējumi par negūtajiem ienākumiem līguma pārkāpuma rezultātā vai nelabvēlīgu seku draudi, ko Apvienotās Karalistes saistību tiesības neatzīst, tādējādi nodemonstrējot, cik sarežğîti dažkārt var būt nošḳirt zaudējumu atlīdzināšanas klauzulu no soda klauzulas [20].

Pēc simts gadiem - 2015. gadā - Apvienotajā Karalistē Augstākā tiesa pārskatīja likumu par soda klauzulām. 2015. gadā, izvērtējot minēto lietu, Anglijā un Velsā likums joprojām bija pret soda klauzulu piemērošanu, taču likumā vairs nav vispārējas prasības par iepriekšēju finanšu zaudējumu aplēsi, slēelzot līgumu, kurus varētu ciest līguma slēdzēja puse, otrai pusei pārkāpjot līgumu [32].

Pēc Dunlop Tyres v New Garage Company lietas var secināt, ka ne katrā līgumā iespējams paredzēt un iepriekš novērtēt visus potenciālos zaudējumus līguma nepienācīgas izpildes dēl, jo īpaši - netiešos zaudējumus, kas varētu rasties negūtu ienākumu veidā. Tādējādi redzams, ka ne vien kontinentālās Eiropas tiesību līgumsods tiek pietuvināts anglosakšu iepriekš novērtēto zaudējumu atlīdzināšanas institūtam, bet arī anglosakšu iepriekš novērtēto zaudējumu institūtam ir nepilnības, kas l̦auj to pietuvināt soda klauzulai.

Lai gan literatūrā par līgumsaistībām, kurā analizēti ekonomiskie procesi, visai bieži valda akadēmiska vienprātība par līgumsodu sodošo dabu, aizvien biežāk parādās diskusijas par to, kā nošķirt šĩ institūta sodošo dabu no zaudējumu atlīdzinošās dabas. Visai bieži, kā piemērā ar Dunlop Tyres v New Garage Company lietu, šì robeža var būt diezgan trausla un grūti identificējama. Galvenais arguments tiesību doktrīnā par labu līgumsodu sodošajai funkcijai ir tas, ka iepriekš novērtēto zaudējumu atlīdzināšanas institūts ne vienmēr pilnībā izpilda savu galveno, proti, kompensējošo funkciju, atstājot vienu no līdzējiem ekonomiski neizdevīgā pozīcijā. Turklāt, dažu autoru skatījumā, līgumsodu ir daudz vienkāršāk piedzīt, jo iepriekš novērtēto zaudējumu atlīdzināšanas institūts būtiski sarežğì līgumus un līguma pārkāpumu gadījumā nereti rodas jauni strīdi. Tāpat tiesību doktrīnā kā arguments par labu līgumsoda sodošajai dabai tiek nosaukts jau agrāk šeit 
pieminētais līgumu slēgšanas brīvības princips. Tomēr jāuzsver, ka šo nevar uzskatīt par visai pārliecinošu argumentu, jo līgumu slēgšanas brīvība tomēr nevienās civiltiesībās nav absolūta un tāda nedrīkstētu būt arī saistību tiesībās.

Salīdzinot līgumsodu iepriekš novērtēto zaudējumu atlīdzināšanas izpratnē un līgumsodu sankcijas izpratnē, var secināt, ka šie divi šḳietami līdzīgie, tomēr visai atšṣirīgie tiesību institūti ne vienmēr ir vienkārši nošķirami, īpaši tādēl, ka tie laika gaitā tiek pietuvināti viens otram, padarot robežškirtni starp tiem aizvien sarežg̀itāk saskatāmu un nodalāmu.

\section{Secinājumi}

1. Līgumsoda evolūciju Latvijā ir ietekmējusi globalizācija, kas saistīta ar geogrāfisko robežu izzušanu, tādējādi saasinot problēmas, tostarp par saistību izpildi un līgumsoda piemērošanu.

2. Kontinentālās Eiropas tiesību sistēmā un anglosakšu tiesību sistēmā līgumsods ir tas tiesību institūts, par kuru izpratne kardināli atšḳiras, jo anglosakšu tiesībās kategoriski netiek atzìts jēdziens "līgumsods", tāpēc ka privāttiesības nevar būt saistītas ar sodīšanu, turpretim kontinentālās Eiropas tiesībās tas ir pavisam normāls tiesību institūts.

3. Starptautiskajos tiesību aktos - gan ar juridisko spēku, gan ar ieteikuma raksturu - līgumsods ir skatīts nevis kā soda mērs, bet gan kā iepriekš novērtētie (vai novērtējamie) atlīdzināmie zaudējumi. Aplūkoto tiesību harmonizācijas aktu regulējums neaizliedz piemērot sodoša rakstura līgumsodu par saistību nepienācīgu izpildi, tomēr šis regulējums vairāk līdzinās anglosakšu tiesību saimei raksturīgajam, kas saistìts vien ar zaudējumu atlīdzināšanu.

4. Ja zaudējumu atlīdzināšanas institūts balstìts uz nosacỉjumu, ka līgumsaistību neizpildes vai nepienācīgas izpildes gadījumā ir nodarìti faktiski un pierādāmi zaudējumi, kas ir jāatlīdzina, tad, istenojot soda klauzulu, nav nepieciešams zaudējumu pierādišanas fakts.

5. Kopš Civillikuma 2013. gada 20. jūnija grozïjumiem līgumsoda kontekstā atklājas atseviški ar to saistīti neatbildèti jautājumi:

- Kā noteikt saistības vērtību?

- Par cik ilga perioda kavējumu līgumsodu var prasīt maksimālā - likumā noteiktā - apmērā, lai tas būtu uzskatāms par samērīgu?

- Kas saprotams ar jēdzienu "galvenā saistība"?

- Kā nošķirt saistību neizpildi vispār no saistību nepienācīgas izpildes vai neizpildes noteiktā laikā?

6. Salīdzinot līgumsodu iepriekš novērtēto zaudējumu atlīdzināšanas izpratnē un līgumsodu sankcijas izpratnē, var secināt, ka šie divi šḳietami līdzīgie, tomēr visai atšḳirīgie tiesību institūti ne vienmēr ir vienkārši nošḳirami. Laika gaitā tie ir pietuvināti viens otram, padarot robežškirtni starp tiem aizvien sarežğîtāk saskatāmu un nodalāmu. 


\section{Impact of Globalisation on the Application of the Contractual Penalty}

\section{Abstract}

The article provides an insight into the nature of the contractual penalty. It aims, by exploring a contractual penalty institute on a global scale, to reveal problems related to the application contractual penalty in current legal environment. In the context of the contractual penalty institute, a priority shall be the issue of applying proportionality principle on a national and global scale. The article compares the understanding of the contractual penalty in various legal systems and the impact of globalisation on the contractual penalty institute in the Republic of Latvia.

Keywords: contractual penalty, penalty clause, liquidated damages.

\section{Avoti un literatūra}

\section{Tiesību akti}

1. Civillikums: Latvijas valsts likums: stājas spēkā 01.09.1992. Valdības Vēstnesis. 41, 20.02.1937. Konsolidētā redakcijā iegūts no: https://likumi.lv/doc.php?id=225418 [sk. 03.04.2018.].

2. Civilprocesa likums: Latvijas Republikas likums: stājas spēkā 01.03.1999. Latvijas Vēstnesis. 326/330(1387/1391), 03.11.1998. Konsolidētā redakcijā iegūts no: https:/likumi.lv/doc. php?id=50500 [sk. 03.04.2018.].

3. Consumer Contracts Law: Principles, Definitions and Model Rules of European Private Law. Draft Common Frame of Reference (DCFR). European Comission. Iegūts no: http://ec.europa. eu/justice/contract/files/european-private-law_en.pdf [sk. 07.04.2018.].

4. Contract Law of the People's Republic of China (Adopted and Promulgated by the Second Session of the Ninth National People's Congress March 15, 1999): KTR likums. Iegūts no: http://www. wipo.int/edocs/lexdocs/laws/en/cn/cn137en.pdf [sk. 07.04.2018.].

5. Eiropas Padomes 1993. gada 5. aprīḷa Direktīva 93/13/EEK par negodīgiem noteikumiem patērētāju līgumos. Eiropas Savienïbas Oficiālais Vēstnesis. L95/29, 21.04.1993.

6. Eiropas Parlamenta un Padomes Direktīva 2008/48/EK par patērina kredïtlīgumiem un ar ko atcel Direktīvu 87/102/EEK: pieñemta 23.04.2008. Eiropas Savienïbas Oficiālais Vēstnesis. L133/66, 22.05.2008.

7. Eiropas Parlamenta un Padomes 2011. gada 16. februāra Direktīva 2011/7/ES par maksājumu kavējumu novēršanu komercdarïjumos, dokuments attiecas uz EEZ. Oficiālais Vēstnesis. L48/1, 23.02.2011.

8. Federal Act on the Amendment of the Swiss Civil Code (Part Five: The Code of Obligations): Šveices likums. Iegūts no: https://www.admin.ch/opc/en/classified-compilation/19110009/201704010000/220.pdf [sk. 07.04.2018.].

9. German Civil Code BGB (Bürgerliches Gesetzbuch): Vācijas likums. Iegūts no: https://www. gesetze-im-internet.de/englisch_bgb/ [sk. 26.10.2017.]. 
10. Indian Contracts Act: Indijas likums. Iegūts no: http://www.advocatekhoj.com/library/bareacts/ indiancontract/74.php?Title=Indian\%20 Contract\%20Act,\%201872\&STitle=Compensation\%20 for\%20breach\%20 of\%20 contract\%20where\%20penalty\%20stipulated\%20for [sk. 20.10.2017.].

11. Krievijas Civilkodekss (ГражАанский кодекс Российской Федерации): Krievijas Federācijas likums. Iegūts no: https://www.consultant.ru/document/cons_doc_LAW_5142/ [sk. 26.10.2017.].

12. Lietuvas Civilkodekss (Civilinis kodeksas): Lietuvas likums. Iegūts no: http://tm.infolex. lt $/$ ?item=taktai_list\&aktoid=50805\&strnr=6.73 [sk. 26.10.2017.].

13. Par Apvienoto Nāciju Organizācijas Konvenciju par starptautiskajiem preču pirkuma-pārdevuma līgumiem. Latvijas Vēstnesis. 170(885), 03.07.1997.

14. Patērētāju tiesību aizsardzības likums: Latvijas Republikas likums: stājas spēkā 15.04.1999. Latvijas Vēstnesis. 104/105(1564/1565). Konsolidētā redakcijā iegūts no: https://likumi.lv/doc. php?id=23309 [sk. 03.04.2018.].

15. Spanish Civil Code: Spānijas likums. WIPO. Iegūts no: http://www.wipo.int/wipolex/en/text. jsp?file_id=221320 [sk. 26.10.2017.].

16. The Civil Code of the France (Le Code civil des Français): Francijas likums. Iegūts no: https://www. legifrance.gouv.fr/affichCode.do?cidTexte=LEGITEXT000006070721\&dateTexte $=20080225$ / [sk. 26.10.2017.].

17. The Civil Code of the Netherlands (Burgerlijk Wetboek): Nìderlandes likums. Dutch Civil Law. Iegūts no: http://www.dutchcivillaw.com/civilcodebook066.htm [sk. 26.10.2017.].

18. The Law of Obligations Act (Võlaõigusseadus): Igaunijas likums. Riigi Teataja. Iegūts no: https:// www.riigiteataja.ee/en/eli/506112013011/consolide [sk. 26.10.2017.].

19. USA Uniform Commercial Code: ASV likums. Legal Information Institute. Iegūts no: https:// www.law.cornell.edu/ucc [sk. 07.04.2018.].

\section{Tiesu prakse}

20. Dunlop Pneumatic Tyre Company Limited v The New Garage and Motor Company Limited 01.07.1914. Doyles. 2005. Iegūts no: https://mosaicprojects.com.au/casewatch/1034\%20 Dunlop\%20v\%20New\%20Garage.pdf [sk. 07.04.2018.].

21. Eiropas Savienības Tiesas spriedums 13.05.2013. lietā C-488/11. Iegūts no: http://curia.europa. eu/juris/document/document.jsf?text=1\%25C4\%25ABgumsods\&docid=137830\&pageIndex=0\& doclang=LV\&mode=req\&dir=\&occ=first \&part=1\&cid=1453608\#ctx1 [sk. 07.04.2018.].

22. Latvijas Republikas Augstākās tiesas Senāta 2005. gada 26. janvāra spriedums lietā Nr. SKC-48. Jurista Vārds. 14(369), 19.04.2005.

\section{Literatūra}

23. Brīvmanis, V. 1939. Lìgumsods. Rìga.

24. Broka, B. UNIDROIT Starptautiskie komerclīgumu principi 2010. Iegūts no: https://www.google. lv/url?sa=t\&rct=j\&q=\&esrc $=$ s\& source=web\&cd=2\&ved=0ahUKEwiGh6i5uu3WAhVGQJoKHdp bD0UQFggrMAE\&url=https\%3A\%2F\%2Fwww.tm.gov.lv\%2Ffiles\%2Farchieve\%2Flv_jaunumi_B_ Broka.pdf\&usg=AOvVaw2YU89_ubfTwhdoMzBb5PQb [sk. 07.04.2018.].

25. García, I. M. 2012. Enforcement of Penalty Clauses in Civil and Common Law: A Puzzle to be Solved by the Contracting parties. European Journal of Legal Studies. 5(1), 100-103.

26. Leng, J., Shen, W. 2016. The Evolution of Contract Law in China: Convergence in Law but Divergence in Enforcement. Cambridge: Cambridge University Press. 17.01.2017. 
27. McKenna, J. F. 2008. Liquidated Damages and Penalty Clauses: A Civil Law versus Common Law Comparission. ReedSmith. Spring, 1-7.

28. Patti, F. P. 2015. Penalty Clauses in Italian Law. Kluwer Law International. Iegūts no: https:// www.academia.edu/29374462/Penalty_clauses_italian_law?auto=download [sk. 07.04.2018.].

29. Pressman, M. 2013. The Two-Contract Approach to Liqudated Damages: a New Framework for Exploring the Penalty Clause Debate. Virginia Law E Business Review. 7, Spring, 656-659.

30. Principles of European Contract Law. Parts I and II. Combined and revised. Prepared by The Commision of Contract Law Chairman: Professor O. Lando. Ed. by O. Lando and H. Beale. The Hague, London, Boston: Kluwer Law International, 2000.

31. Relating to penal clauses in civil law: Resolution (78)3, adopted by the Committee of Ministers on 20 January 1978. Iegūts no: https://rm.coe.int/CoERMPublicCommonSearchServices/Disp layDCTMContent?documentId=0900001680505599 [sk. 07.04.2018.].

32. Roberton, M. 2017. In terrorem "Penalty clauses" in contracts - the Scottish Law Commission review. Mitchells Roberton. Iegūts no: http://www.mitchells-roberton.co.uk/bullet-point-update/ february-2017-in-terrorem-penalty-clauses-in-contracts-the-scottish-law-commission-review/ [sk. 30.10.2017.].

33. Tiesu prakse līgumsodu piemērošanā. Latvijas Republikas Augstākā tiesa, Senāta Civillietu departaments, 2013.

34. Torgāns, K. Līgumsods nosakāms konkrētā summā. Jurista Vārds. 4(755), 29.01.2013.

35. Torgāns, K. 2013. Lìgumu un deliktu tiesību problēmas. Rīga: Tiesu namu aǵentūra.

36. UNIDROIT Principles of International Commercial Contracts 2016. Iegūts no: https://www. unidroit.org/instruments/commercial-contracts/unidroit-principles-2016 [sk. 07.04.2018.]. 


\title{
Autoru tiesiskā aizsardzība digitālajā vidē
}

\author{
Mg. iur. Liene Vindele \\ Rīgas Stradiṇa universitāte, Doktorantūras nodaḷa, \\ Juridisko zinātṇu programma, Latvija \\ vindele.liene@gmail.com
}

\section{Kopsavilkums}

Attīstot digitālās tehnologijas, tika radītas jaunas iespējas dalīties ar dažādu tautu kultūras mantojumu un zinātnisko jaunradi. Šis process turpinās, l̦ajot sabiedrībai arvien vairāk izmantot intelektuālo īpašumu, taču tā autori bieži vien nesaṇem samaksu par savu veikumu, jo citiem ir vilinoši intelektuālo īpašumu lietot bez maksas, turklāt to var izdarìt ērti un vienkārši.

Digitālās vides pārmaiṇu dẹl aktuālāki kḷuvuši arī autortiesību jautājumi, tāpēc vairāk uzmanības jāpievērš tiesiskā regulējuma trūkumiem, kas konstatēti ne tikai Latvijā, bet arī visā pasaulē. 2015. gada maijā Eiropas Savienībā tika apstiprināta Digitālā vienotā tirgus stratēgija, kuras mērḳis ir rast risinājumus, kā samazināt atšķirības valstu autortiesību aizsardzības kārtībā un lietotājiem nodrošināt plašāku tiešsaistes piekḷuvi darbiem.

Šajā pētỉjumā ir analizēta autoru darbu tiesiskā aizsardzība digitālajā vidē un ar to saistītās problēmas, kā arī meklēti risinājumi, lai tiesiskais regulējums kḷūtu efektīvāks, mazinātu nelegālā satura izmantošanu un atturētu sabiedrību no autortiesību pārkāpumiem digitālajā vidē.

Veicot šo pētijumu, galvenokārt tika lietota dokumentu analīzes metode - tiesiskā regulējuma analīzei tika izmantoti starptautiskie un nacionālie tiesību akti, kā arī Eiropas Savienības Tiesas spriedumi par autortiesību pārkāpumiem digitālajā vidē. Darbā ir aplūkoti arī autortiesību jautājumu pētnieku - Biznesa augstskolas "Turība" profesores Ingrīdas Veikšas, Eiropas Komisijas par digitālās ekonomikas un sabiedrības jautājumiem atbildīgā komisāra Gintera H. Etingera un Latvijas Republikas Augstākās tiesas zinātniski analītiskā padomnieka Riharda Gulbja - viedokḷi.

Atslēgvārdi: autortiesības, digitālā vide, internets, pārkāpumi. 


\section{levads}

Autortiesības ir dal̦a no intelektuālā īpašuma tiesībām, kuru darbības galvenā būtība ir vairot jaunradi un aizsargāt autora īpašumtiesības. Attīstoties tehnologijām, mainās arī ar autortiesībām aizsargātu darbu radīšanas un izmantošanas iespējas, tāpēc rodas nepieciešamība pēc jauniem risinājumiem tiesību aizsardzībai. Šobrīd visā pasaulē ir aktuāla autortiesību tiesiskā aizsardzība digitālajā vidē. Arī Latvijā notiek tiesiskās aizsardzības uzlabošana.

Eiropas Komisijas par digitālās ekonomikas un sabiedrības jautājumiem atbildīgais komisārs Ginters H. Etingers norāda, ka "mūsu ekonomika un sabiedrība pievēršas digitalizācijai. Nākotnes labklājība lielā mērā būs atkarīga no tā, cik labi mēs tiksim galā ar šo pāreju. Mums ir jāsagatavojas mūsdienīgai sabiedrībai un būs jāiesniedz priekšlikumi, lai līdzsvarotu patērētāju un rūpniecības intereses" [17].

Intelektuālajam īpašumam piemìt neierobežota, globāla mobilitāte, kas ḷauj to viegli pārvietot un èrti nogādāt jebkurā pasaules vietā. Tomēr tā aizsardzībai piemīt arī teritoriāls raksturs. Tādēl l̦ loti būtiska ir starptautisko līgumu un konvenciju loma, lai autoru interešu nodrošināšana būtu vienlaikus aizsargāta daudzās valstīs. Pamatojoties uz šiem starptautiskajiem dokumentiem, vienā valstī atbilstīgi tās likumiem radītām autortiesībām jādarbojas un jābūt aizsargātām citā valstī saskaņā ar tās likumiem [19].

Latvijas Republikas Satversmes 113. pantā ir nostiprināta autortiesỉbu aizsardzība: "Valsts atzīst zinātniskās, mākslinieciskās un citādas jaunrades brīvību, kā arī aizsargā autortiesības un patenttiesības." [4] Tomēr autortiesību aizsardzība, it īpaši digitālajā vidē, ir Latvijā viens no aktuālākajiem jautājumiem.

Latvijas pētijumu centra SKDS 2016. gadā veiktajā aptaujā 46\% intervēto atzina, ka audio un video ierakstu, kā arī datorprogrammu pirātisms ir attaisnojams, turklāt $28 \%$ respondentu šim apgalvojumam piekrita daḷēji, bet 18\% - pilnīgi [21]. Savukārt Eiropas Savienības Intelektuālā īpašuma birojs 2017. gada 23. martā publicēja pētỉjuma "Eiropas pilsoṇi un intelektuālais īpašums - uztvere, informētība un rīcība" rezultātus [18]. Šajā aptaujā $67 \%$ respondentu intelektuālo īpašumu pielīdzināja ekonomiskās stabilitātes saglabāšanai. Tomēr puse aptaujāto uzskatīja, ka intelektuāā īpašuma stingra aizsardzība var ierobežot inovācijas, un vairāk nekā puse atzina, ka intelektuālā īpašuma principi nav pielāgoti internetam.

Lai gan sabiedrības attieksmē pret autortiesībām kopumā ir vērojama pozitīva tendence, tomēr redzams, ka autortiesību tiesiskais regulējums nav pielāgots digitālajam laikmetam. Tāpēc tiek radīti sabiedrības ierasto darbỉbu ierobežojumi, piemēram, nepārtrauktās hipersaišu straumēšanas sociālajā vietnēs ierobežojumi. Šobrīd ir brīvi pieejamas tīmekḷa vietnes, kurās var noskatīties dažādus audiovizuālus darbus. Rodas jautājums, vai šāda darbība ir legāla vai, tieši pretēji - nelegāla? Tāpat arī arvien vairāk neskaidrību rodas par digitālajā vidē pieejamā satura tiesiskumu. Kā atšḳirt legālu saturu no nelegāla? 


\section{Autortiesību tiesiskā regulējuma attīstība}

Par autortiesībām kā tiesību normu var runāt, sākot ar 1710. gada Annas statūtiem Lielbritānijā [10], kas grāmatu izdevējiem piešḳīra monopola tiesības uz grāmatu izdošanu un citas ekskluzīvas tiesības. Annas statūtu mērḳis bija novērst grāmatu iespiešanu un izplatīšanu bez autoru piekrišanas.

Mūsdienās autortiesību regulējums iekḷauts starptautiskās konvencijās, Eiropas Savienībā tās regulē direktīvas, un katra valsts tās iekḷāvusi nacionālajos tiesību aktos. Bernes konvencijā par literatūras un mākslas darbu aizsardzību [3] (turpmāk - Bernes konvencija) noteikts, ka valstīm ir pienākums aizsargāt literatūras un mākslas darbus neatkarīgi no to izpausmes veida un formas, piemēram, grāmatas, brošūras, lekcijas, runas, dramatiskos un muzikāli dramatiskos darbus, horeogrāfiskos darbus un pantomīmas, muzikālās kompozīcijas ar tekstu vai bez tā, glezniecības, arhitektūras, tēlniecības, grafikas un litogrāfijas darbus, fotogrāfiskos darbus, kuriem pielīdzināmi darbi, kas izpildīti fotogrāfijai analoǵiskā veidā, un lietišḳās mākslas darbus.

Savukārt Apvienoto Nāciju Organizācija (ANO), 1948. gadā pieṇemot Vispārējo cilvēktiesību deklarāciju [2], noteica tiesības, kas tika uzskatītas par cilvēkam būtiski svarīgām, un šajā dokumentā tika ietvertas arī autortiesības. Deklarācijas 27. panta 2. apakšpunktā teikts: "Katram cilvēkam ir tiesības uz morālo un materiālo interešu aizsardzību, kas saistītas ar zinātniskajiem, literārajiem vai mākslas darbiem, kuru autors vin,š ir."

Autortiesības ir kḷuvušas par pamattiesībām, kuru nodrošināšana un veicināšana ir visu pasaules valstu pienākums. Tomēr valstu autortiesību aizsardzības normu interpretācija, kā arī tiesību piemērošana ievērojami atškরiras. Piemēram, atšḳirībā no Eiropas valstu autortiesību sistēmā ietvertajiem “izṇēmumiem un ierobežojumiem” Amerikas Savienotajās Valstīs pastāv taisnīgas izmantošanas prakse (fair use).

Attīstot digitālo vidi un sniedzot pārrobežu tiešsaistes pakalpojumus, parādījās un kḷuva aktuāli vairāki autortiesību un to piemērošanas prakses trūkumi, kuru novēršana ir l̦oti svarīga, lai Eiropas Savienībā izveidotu uz zināšanām balstītu ekonomiku un vienotu digitālo tirgu. Reaǵējot uz straujo interneta un tehnikas progresu, kā arī nolūkā uzlabot autortiesību un blakustiesību aizsardzību digitālajā vidē, tika domāts arī par to, lai sabiedrībai tiktu saglabāta un uzlabota šo darbu pieejamība. Līgumu izstrādātāji sākotnēji nebija vienprātīgi par to, kurām tiesībām pakārtot autoram piekritīgās izṇēmuma tiesības savu darbu izmantošanai internetā - daži bija par reproducēšanas un izplatīšanas tiesībām, citiem piemērotākas šḳita raidīšanas tiesības. Galu galā tika panākta vienošanās par jaunu tiesību definēšanu, autoram garantējot viṇa darbu digitālās izplatīšanas kontroli. Vienlaikus tika atzìts, ka šìs tiesības viṇam ir piekritīgas arī gadījumā, ja darbs tiek ievietots internetā [23].

Mūsdienās visā pasaulē ir aktuāla intelektuālā īpašuma tiesiskā aizsardzība, arī Latvijā tiek uzlabota intelektuālā îpašuma tiesiskā aizsardzība. Ministru kabinets ir apstiprinājis intelektuālā îpašuma tiesību aizsardzības un nodrošināšanas 
pamatnostādnes 2015.-2020. gadam, nosakot šajā periodā Latvijas valdības politikas pamatprincipus, mērḳus un rīcības virzienus intelektuālā ìpašuma tiesību aizsardzībā un nodrošināšanā:

- attīstību - jaunu produktu un tehnologiju izstrādes un ražošanas attīstības iespējas;

- sadarbību - valsts institūciju un privāto institūciju savstarpēju sadarbošanos, sadarbỉbu starp pētniekiem un uzñēmējiem;

- izpratni - informētību intelektuālā īpašuma tiesību jomā, tostarp informētību par intelektuālā ìpašuma tiesību lietojumu savu tiesību aizsardzībā [5].

Kas ir autortiesību pārkāpums? Autortiesību likuma 68. pantā [2] noteikts, ka par autortiesību un blakustiesību pārkāpumu uzskatāma darbība, ar kuru aizskartas autortiesību un blakustiesību subjekta personiskās vai mantiskās tiesības, tostarp autortiesību un blakustiesību objektu fiksācija, to publicēšana, publiskošana, reproducēšana un izplatīšana jebkādā veidā bez autortiesību un blakustiesību subjekta piekrišanas.

Pienākums saṇemt autortiesību subjekta ațlauju darba izmantošanai attiecas uz visiem darba izmantotājiem. Par autortiesību pārkāpšanu ir paredzēta civiltiesiskā, administratīvā un arī krimināltiesiskā atbildība. Tomēr Latvijas Republikas Augstākās tiesas Senāta Krimināllietu departamenta 2006. gada 18. aprīḷa lēmumā lietā SKK-213/06 [15] norādīts, ka autortiesību likumā reglamentētās formas neievērošana par to, kā jāsaṇem aț̣auja autora darbu izmantošanai, nevar būt kā vienīgais kritērijs personas kriminālatbildībai par autortiesību pārkāpumu. Tiesa arī atzina, ka svarīgi ir noskaidrot noziedzīgā nodarījuma subjektīvo pusi.

Atbilstošas prasības definētas arī starptautiskajos tiesību aktos par autortiesību krimināltiesisko aizsardzību. Pasaules Tirdzniecības organizācijas līguma par intelektuālā īpašuma aspektiem, kas saistīti ar tirdzniecību (TRIPS) [6], 61. pantā paredzēts, ka kriminālatbildībai jābūt obligātai, ja darbība aptver trīs elementus: autortiesību pārkāpumu, pārkāpējs apzinājies savas darbības raksturu, un darbība veikta komerciālu mērķu sasniegšanai. Starp materiāla labuma gūšanu un nelikumīgu autortiesību objekta izmantošanu jābūt tiešai saiknei. Vainīgajai personai jāgūst materiāls labums tieši ar šo objektu izmantošanu paredzētajam nolūkam [15].

\section{Autortiesību pārkāpumi digitālajā vidē}

Digitālās vides attīstība ir mainījusi pasauli, skarot visas valstis, tāpēc svarīgi ir domāt par tiesisko regulējumu, kas intelektuālā īpašuma autorus spētu aizsargāt ne tikai ar nacionālajām tiesību normām, bet arī starptautiski. Modernās tehnolog̣ijas ḷauj piekḷūt intelektuālajam īpašumam daudzās valstīs, apejot teritoriālos ierobežojumus, tāpēc, no tiesību aizsardzības viedokḷa raugoties, autoru darbi kḷūst arvien apdraudētāki. Hipersaites ir kḷuvušas par vienu no aktīvāk izmantotajiem komunikācijas veidiem, tomēr šo darbību tiesiskuma aspekts ne vienmēr ir skaidrs. 


\begin{abstract}
Profesore Ingrīda Veikša norāda:
"Hipersaites ir kḷuvušas par galveno tehnolog̣iju, ar kuras palīdzību internets funkcionē šodien, hipersaites regulāri tiek izmantotas internetā, tai skaitā jaunajos tiešsaistes pakalpojumos. Interneta attīstības gaitā datu saistǐšana ir kḷuvusi par būtisku komunikācijas formu, kas plaši tiek izmantota sociālajās platformās un jaunajos komunikāciju tīklos (no Facebook līdz Twitter). Tiesību normās trūkst skaidras norādes par šo jautājumu, nacionālie tiesneši un likumdevēji ir snieguši pretrunīgas atbildes uz jautājumu par to, vai interneta pakalpojumu sniedzēji un lietotāji var vai nevar brīvi lietot saistīšanas darbības internetā. Tāpēc ir nepieciešama precīza atbilde, lai pārliecinātos, ka tiešsaistes pakalpojumi tiek likumīgi piedāvāti internetā un ka tīmekḷa lietotāji var baudīt vārda brīvību, ko internets vienmēr ir tiem nodrošinājis. Saiknes izveidošanas likumība būtu jāvērtē, n, nemot vērā apstākli, vai šāda saikne var paplašināt potenciālo darba saṇēmēju loku, padarot to pieejamu plašākam lietotāju skaitam, nekā tiesību subjekta paredzētais." [26]
\end{abstract}

Eiropas Savienïbas Tiesa, izskatot lietu Nr. C-160/15 GS Media BV pret Sanoma Media Netherlands BV, Playboy Enterprises Interntional Inc., Britt Geertruida Dekker [12] par hipersaišu izvietošanu, kas dod piekḷuvi aizsargātiem darbiem, kuri padarīti pieejami citā interneta vietnē bez īpašnieka ațlaujas, norādīja, ka jānovērtē, vai bijusi "izziṇošana" sabiedrībai, proti, vai interneta vietnē ir ievietota hipersaite uz aizsargātiem darbiem, kuri citā interneta vietnē ir brīvi pieejami bez autortiesību īpašnieka aț̣ajas. N̦emot vērā, ka hipersaite un interneta vietne, uz kuru tā aizved, dod piekḷuvi aizsargātam darbam vienā un tajā pašā tehniskajā veidā, proti, internetā, šādai saitei jābūt adresētai jaunai sabiedrībai (t. i., pie informācijas (autordarba) piekḷūst cita - jauna - sabiedrības dạ̣a, kura pati bez pārkāpēja palīdzības nevarētu to izdarìt). Ja tā nav, it īpaši tāpēc, ka darbs jau ir brīvi pieejams visiem lietotājiem citā interneta vietnē ar autortiesību īpašnieku aț̣auju, tad šo darbību nevar kvalificēt par "izziṇošanu" sabiedrībai. Tiklīdz un tā kā šis darbs ir brīvi pieejams interneta vietnē, kurai l̦auj piekḷūt hipersaite, jāuzskata, ka šĩ darba autortiesību īpašnieki ir aṭ̦āvuši šādu "izziṇošanu" un visus interneta lietotājus tie ir uzskatījuši par sabiedrību.

Būtiska ir šāda tiesas norāde: ja hipersaiti uz citā interneta vietnē brīvi pieejamu darbu ielikusi persona, kuras rīcības mērḳis nebija peḷnas gūšana, jāṇem vērā, ka šī persona nezina un nevarēja zināt, ka šis darbs ir ticis publicēts internetā bez autortiesību îpašnieka atḷaujas. Proti, šì persona, nododot darbu sabiedrības rīcībā un pārējiem interneta lietotājiem piedāvājot tam tiešu piekḷuvi, parasti nerīkojas, pilnībā apzinoties savas rīcības sekas, kas rodas, sniedzot klientiem piekḷuvi darbam, kas internetā ievietots prettiesiski. Jāatceras, ka šis darbs jau bija pieejams interneta vietnē, kurai bez ierobežojumiem var piekḷūt ar hipersaites palīdzību, un visi interneta lietotāji jau varēja ar to iepazìties arī bez šìs iejaukšanās. Līdzīgi ir gadījumā, ja saite ḷauj interneta vietnes, kurā ir šĩ saite, lietotājiem apiet ierobežojumus, kas ir vietnē, kurā atrodas aizsargātais darbs, lai publisku piekḷuvi dotu tikai abonentiem. Šãdas saites ievietošana ir apzināta iejaukšanās, bez kuras minētie lietotāji nevarētu tikt pie izplatītajiem darbiem [12]. 
Ja hipersaite tiek izvietota, lai gūtu pel̦nu, tiek sagaidīts, ka saites izvietotājs jau ir veicis nepieciešamās pārbaudes un pārliecinājies, ka attiecīgais darbs vietnē, uz kuru ved šì hipersaite, nav publicēts prettiesiski, un var uzskatit, ka hipersaite izvietota, apzinoties, ka darbs tiek aizsargāts un ka autortiesību īpašnieks droši vien nav aṭ̣āvis to publicēt internetā. Šādos apstākḷos, ciktāl šis pieṇēmums netiek atspēkots, hipersaites uz internetā prettiesiski publicētu darbu ievietošana ir "izzinnošana" sabiedrībai [12].

G̣enerāladvokāts Melhiors Vatelē norāda, ka, nodrošinot lielāku juridisko noteiktību un intelektuālā īpašuma labāku aizsardzību, autortiesību un blakustiesību saskaṇots tiesiskais regulējums veicinās būtisku ieguldījumu jaunradē un jauninājumos, tostarp tīklu infrastruktūrā, kas savukārt veicinās Eiropas rūpniecības izaugsmi un konkurētspējas palielināšanos gan satura un informācijas tehnologiijas jomā, gan arī daudzās ražošanas nozarēs un kultūrā vispār. Attīstot tehnologiijas, jaunrades, ražošanas un izmantošanas iespējas ir palielinājušās un kḷuvušas daudzveidīgākas. Kaut arī nav vajadzīgas jaunas intelektuālā īpašuma aizsardzības koncepcijas, būtu jāpielāgo un jāpapildina esošie tiesỉbu akti par autortiesībām un blakustiesībām, lai tie atbilstu ekonomiskajam stāvoklim, piemēram, jauniem izmantošanas veidiem [14].

Autortiesību skeptiḳi uzskata, ka mūsdienu cīṇa ar interneta pirātismu atgādina notikumus senās pasakās - bruṇinieki, cīnoties ar daudzgalvainiem pūksiem, panāca to, ka pū ḳim vienas nocirstās galvas vietā izauga vairākas citas. Un tomēr sabiedrībai nepieciešams noteikt darbības ierobežojumus, lai negrautu autortiesību aizsardzības sistēmu. Svarīgi ir radīt vidi, kurā sabiedrība autora darbam var piekḷūt vieglāk un legāli, nevis nelegāli. Digitālais laikmets gan nojauc robežas starp valstīm, taču tās netiek nojauktas tiesiskajā jomā. Autortiesību aizsardzība paliek katras valsts ziṇā, bet tiesību interpretācijas atšḳirības praksē rada tiesiskus pārkāpumus. Tāpēc autortiesību aizsardzībā var izvirzì šãdus galvenos principus:

- nacionālās piederības principu - digitālajā vidē, kur nav robežu informācijas piekḷuvei, tās izplatītājs var viegli izvēlēties informācijas glabāšanas valsti, šādā veidā izvairoties no tiesiskās atbildības par pārkāpumiem;

- pārkāpuma valsts (vietas) principu - nosakot, ka pārkāpuma vieta ir tā, kur ši informācija būs pieejama. Ja informācija, kura ir legāla valstī, kurā atrodas serveris, būs pieejama valstī, kur tā būs prettiesiska, varēs konstatēt, ka ir pārkāptas šìs valsts tiesiskās normas;

- valsts piederības princips - atbilstīgi tās valsts tiesību normām, kurā izvietots domēns, tiks analizēta atbildība par izdarìto pārkāpumu.

Kādēḷ nepieciešama autortiesību aizsardzība? ASV korporācijas Apple Inc. dibinātājs Stīvs Džobss uzskata:

“Jau pašā sākumā, strādājot Apple, es atskārtu, ka mēs plaukstam un zeḷam, radot intelektuālo īpašumu. Ja cilvēki kopētu un zagtu mūsu programmatūru, mēs bankrotētu. Ja mēs nebūtu pasargāti, mums nerastos motivācija izgatavot jaunu programmatūru vai produktu dizainu. Ja intelektuālā īpašuma aizsardzība izzudīs, tad arī uzñēmumi, kas rada šo īpašumu, vai nu izzudīs, vai arī nekad netiks dibināti. Taču pastāv kāds vienkāršāks iemesls: zagt nav labi. Zagšana nodara kaitējumu citiem cilvēkiem. Un tā kaitē arī mūsu personībām.” [16] 
Lai gan sabiedrība saprot, ka zagt nav labi, tomēr autortiesību jautājumos nez kāpēc sabiedrībā valda tieši pretēja attieksme. Pastāv vairāki uzskati, kāpēc autortiesību tiesiskā aizsardzība ir nepietiekama: vieni argumentē, ka sabiedrībā nav pilnīgas izpratnes par intelektuālā īpašuma jautājumiem, citi uzskata, ka problēma slēpjas taisnīgā atlīdzībā par izmantoto darbu. Varbūt vainojama tiesiskā regulējuma nepietiekamība vai, tieši pretēji - pārāk bargie priekšnosacījumi, lai iegūtu un izmantotu autora darbus? Autortiesību būtība ir šāda: katram autoram ir tiesības saṇemt atalgojumu par radìto darbu, taču arī sabiedrībai ir tiesības tam piekḷūt un baudìt kultūras un zinātnes sasniegumus.

Pētỉjuma rezultāti parāda, kā Eiropas Savienības valstu pilsoṇi uztver intelektuālo īpašumu, kāda ir vinu informētība par šo jautājumu un kāda ir rīcība. Svarīgi ir rast veidu, lai ikviens sabiedrības loceklis var pārliecināties, vai piedāvātais produkts ir legāls vai nelegāls. Diemžēl bieži vien nevar saskatìt atšķirības starp legāla un nelegāla satura piedāvājumiem.

Latvijas Kultūras ministrija sadarbībā ar Eiropas Savienības Intelektuālā īpašuma biroju (EUIPO) ir izveidojusi interneta vietni “N̦em droši!", kurā piedāvā legālu saturu - televīzijas pārraides, filmas un radio raidījumus. Iespējams, ka jādomā par vienotas autoru darbu datubāzes izveidošanu. Piemēram, varētu radīt audiovizuālu darbu informācijas datubāzi, kurā būtu informācija par autoriem, autortiesību īpašniekiem, aizsardzības termiṇiem un kā legāli iegādāties licenci autora darba izmantošanai. Lai gan Bernes konvencijā paredzēts, ka autoru darbus nav nepieciešams registrēt kā, piemēram, patentus, tomēr patlaban autortiesību sistēmu var salīdzināt ar lielceḷu bez cel̦azīmēm. Protams, ir pieṇemti noteikumi, dažādas direktīvas, Ministru kabineta dokumenti, bet digitalizācijas laikmetā patērētājs ikdienā izvēlēsies vieglāko ceḷu, lai iegūtu sev vajadzīgo autora darbu, diemžēl izmantojot pirātisku cel̦u. Tāpēc autortiesību sistēma jārada tāda, lai tās izmantotājiem tā būtu ērti pieejama un saprotama. Veidi un formas, kā patērētājs lieto autoru darbus, laika gaitā ir būtiski mainījušies, un tagad ir nepieciešami jauni risinājumi.

Eiropas Komisija ir noteikusi, ka autortiesībām jākḷūst mūsdienīgākām un eiropeiskākām, lai samazinātu atšḳirības starp valstu autortiesību sistēmām un nodrošinātu plašāku tiešsaistes piekḷuvi darbiem visā Eiropas Savienībā, îstenojot arī turpmākas saskaṇošanas pasākumus. Mērḳis ir uzlabot iedzīvotāju piekḷuvi kultūrai, tādējādi veicinot kultūras daudzveidību, un vienlaikus pavērt jaunas iespējas autoriem un saturam [17].

Tehnologiiskais progress veicina izmaiṇas, kas saistitas ar autortiesībām aizsargāta satura izplatīšanu un izmantošanu. Ir nepieciešams piemērot tādas autortiesību normas, kurās tiek n,emtas vērā šĩs izmaiṇas, turklāt analogajai videi paredzētais regulējums iespēju robežās jāpiemēro digitālajai videi. Lai gan tiesiskajās normās tika iekḷautas tiesības, kas padarīja darbu pieejamu, lai regulētu ar autortiesībām aizsargātu darbu izmantošanu digitālajā vidē, šo tiesību saturs un īstenošanas vietas lokalizācija (piemēram, vai tā ir valsts, kur darbs ir augšupielādēts, vai augšupielādes veicēja domicila valsts, vai valsts, kurā darbs ir pieejams vai kuras iedzīvotājiem paredzēts) sagādā grūtības gan teorētiski, gan praktiski [20]. 
G̦enerāladvokāts Pedro Krusa Viljanons Eiropas Savienības Tiesas (turpmāk arī EST) lietā Nr. C-314/12 UPC Telekabel Wien GmbH pret Constantin Film Verleih GmbH, Wega Filmproduktionsgesellschaft $m b H$ [11] secinājumos norāda, ka nav daudz izgudrojumu, kas mūsu paradumus un mediju izmantošanas veidu mainïjuši tik ḷoti kā internets. Mums ierastais informācijas tīkls nav pat 30 gadu vecs, bet saziṇu un informācijas apmaiṇu tas padara iespējamu visā pasaulē. Tomēr jaunās tehnologijas paver iespēju to izmantot l̦aunprātīgos nolūkos. Tas īpaši attiecas uz autortiesību pārkāpumiem internetā. Tiesību īpašnieki iebilst pret vietnēm, kurās tiek pārkāptas autortiesības. Tomēr interneta pakalpojumu piegādātāi bieži vien atrodas ārzemēs (ārpus Eiropas Savienības) vai slēpj savu identitāti. Tiesību ippašnieki savu mērḳi mēǵina sasniegt, gan prasot noteikt pagaidu pasākumus pret interneta pakalpojumu piegādātājiem, gan bloḳēt piedāvājumus, kuru sniedzēji pārkāpj tiesības.

Lietā UPC Telekabel Wien GmbH pret Constantin Film Verleih GmbH, Wega Filmproduktionsgesellschaft mbH Oberster Gerichtshof (Austrija) divas filmu sabiedrības konstatēja, ka interneta vietnē bez to piekrišanas tiek piedāvāts lejupielādēt vai skatìties tiešsaistē filmas. Handelsgericht Wien (Austrija) aizliedza UPC Telekabel ḷaut saviem klientiem interneta piekḷuvi vietnei. Tas izraisīja strīda situāciju, un šo aizliegumu vajadzēja īstenot, bloḳējot vietnes aktuālo domēna vārdu un IP adresi, kā arī jebkuru citu IP adresi, kuru šì sabiedrība varēja zināt [11].

Šajā gadījumā tiesa norādīja, ka par starpnieku jāuzskata persona, kas interneta vietnē bez tiesību subjekta piekrišanas sabiedrības rīcībā nodod aizsargātus objektus, un ka interneta pakalpojuma piegādātāja veiktajiem pasākumiem jābūt mērḳtiecīgiem, tiem jāizbeidz trešās personas autortiesību vai blakustiesību pārkāpumi, vienlaikus neskarot tos interneta lietotājus, kas izmanto pakalpojumus, lai likumīgi piekḷūtu informācijai. Pretējā gadījumā interneta pakalpojuma piegādātāja iejaukšanās lietotāju informācijas brīvībā būtu nepamatota [11].

Izvērtējot šo tiesas nolēmumu, var secināt, ka gadỉjumā, ja valsts par nelegāla satura izplatišanu prasītu atbildību no interneta pieslēguma nodrošinātāja vai liktu tam filtrēt pārraidìtos datus un bloḳētu nelegālu datu pārraidi, protams, šāda prasība varētu būt nesamērīga un prasītu papildu resursus. Tomēr problēmu risināšanai jānosaka interneta pieslēguma nodrošinātāja līdzdalība. Piemēram, ja autortiesību īpašnieks vēršas pie interneta pieslēguma nodrošinātāja konstatēta autortiesību pārkāpuma dēl un tiek ignorēts, šādā gadỉjumā jāiestājas tā atbildỉbai.

Autortiesību likuma 69. panta 7. punktā [2] noteikts, ka autortiesību un blakustiesību subjekti, kolektīvā pārvaldījuma organizācijas un citi autortiesību un blakustiesību subjektu pārstāvji ir tiesīgi prasît, lai starpnieki, kuru sniegtie pakalpojumi tiek izmantoti nolūkā pārkāpt autortiesību vai blakustiesību subjektu tiesības vai kuri padara iespējamu šādu pārkāpumu, veic attiecīgus pasākumus, lai pārtrauktu izmantotāju iespējas izdarīt šādus pārkāpumus. Ja starpnieks neveic attiecīgus pasākumus, autortiesību vai blakustiesību subjektam vai tā pārstāvim ir tiesības vērsties pret starpnieku. 
Priekšlikumā, kas izstrādāts Eiropas Parlamenta un Padomes direktīvas par autortiesībām vienotajā tirgū 13. pantam, iekḷauts, ka informācijas sabiedrības pakalpojumu sniedzēji, kas lielā apjomā glabā savu lietotāju augšupielādētus darbus vai citus tiesību objektus, sadarbībā ar tiesību īpašniekiem veic pasākumus, kuri nodrošina, ka funkcionē ar tiesību īpašniekiem noslēgtie nolīgumi par viņu darbu vai citu tiesību objektu izmantošanu vai pakalpojumos nav pieejami darbi vai citi tiesību objekti, ko sadarbïbā ar pakalpojumu sniedzējiem identificējuši tiesību īpašnieki. Šie pasākumi, piemēram, rezultatīvu satura atpazīšanas tehnoloǵiju izmantošana, ir lietderīgi un samērīgi. Pakalpojumu sniedzēji tiesību īpašniekus nodrošina ar atbilstīgu informāciju par minēto pasākumu ieviešanu un darbību, kā arī attiecīgā gadījumā atbilstīgi ziṇo par darbu un citu tiesību objektu atpazišanu un izmantošanu [24].

Direktīvā iekḷautā norma jau saṇēmusi asu kritiku, ka Eiropas Komisija cenšoties atbildību par saturu, kas aizsargāts ar autortiesībām, delegeèt interneta uzṇēmumiem, kuru tīmekḷu vietnēs lietotāji augšupielādē videoklipus, piemēram, YouTube un Facebook, t. i., lai tie aktīvi pārbaudītu ar autortiesībām aizsargāto materiālu, nevis tikai reageètu uz tiesību ipašnieku pieprasījumiem. Eiropas Parlamenta deputāte Jūlija Reda uzskata, ka, pieṇemot direktīvas 13. pantu, tiks ierobežota vārda brīvība. Programmatūra nevarēs noteikt, vai autordarbs tiek lietots legāli, piemēram, vai tas domāts kā parodija, kas tiek piel̦auts kā autortiesību izṇēmums. Filtri arī bieži vien darbojas nepareizi. Savukārt, ja identifikācija izrādīsies kḷūdaina, tiks uzskatīts, ka noticis pārkāpums, proti, faktiski interneta uzñēmumus uzskatīs par "vainīgiem līdz brīdim, kad tie būs pierādījuši nevainību”. Turklāt šì prasība radīs milzịgu slogu interneta kompānijām un kavēs investīcijas lietotāju radītajos satura veidošanas procesos [24].

Tomēr svarīgi atzīmēt, ka tiesību īpašnieks nedrīkst būt neaizsargāts pret vietnēm, kurās tiek pārkāptas viṇa tiesības, tādēl jādomā par tiesisko regulējumu, kas lautu laikus reagêèt uz tiesiskiem pārkāpumiem interneta vietnēs.

2018. gada februāra beigās Valsts policija pārtrauca divu Latvijā populāru tìmekḷa vietṇu darbību, kurās, pārkāpjot autortiesības, tika nelegāli retranslētas filmas. Šo tīmekḷ vietṇu darbības dēḷ satura īpašniekiem tika radīti zaudējumi kopumā vairāk nekā 200000 eiro. Vienā no šìm tīmekḷa vietnēm tiešsaistē tika nodrošināta aptuveni 2500 nelicencētu filmu straumēšana, kuras apmeklētājiem bija pieejamas bez maksas jau kopš 2013. gada. Izmeklēšanā tika iegūta informācija, ka nelegālo pakalpojumu ikdienā izmantoja aptuveni 27000 pastāvīgo lietotāju [21].

Daudzas valstis lūgušas vietējos interneta pakalpojumu sniedzējus bloḳēt piekḷuvi vietnēm, kurās notiek nelegāla darbība, piemēram, kibernoziegumi vai terorisma veicināšana. Šis ir viens no nedaudzajiem līdzekliiem, lai reageètu uz nelegālu materiālu izvietošanu. Tomēr, runājot par citiem likumīgiem sabiedriskās politikas mērḳiem, piemēram, digitālā pirātisma ierobežošanu, jākonstatē, ka dažās valstīs kūtri tiek prasīts, lai interneta pakalpojumu sniedzēji bloḳētu vietnes, kas paredzētas filmu, mūzikas un citu ar autortiesībām aizsargātu darbu izplatīšanai. Iznākumā tiešsaistes pirātisms nemainīgi turpinās. 2015. gadā veiktajā pētījumā, ko īstenoja Kārnegi Melona (Carnegie Mellon) 
universitāte, tika pārbaudīta vietṇu bloḳēšanas ietekme Apvienotajā Karalistē. Tika konstatēts, ka vienas tīmekḷa vietnes bloḳēšana nav efektĩva, lai palielinātu legālo vietṇu izmantošanu, bet 19 vietṇu bloḳēšana palielināja legālo vietṇu izmantošanu par $12 \%$. Pētījuma rezultāti pierādīja, ka, samazinot nelegāla satura vietṇu skaitu, dažus "pirātus" var padarīt par likumīgiem patērētājiem [25]. Šis pētījums apstiprina, ka, piedāvājot viegli pieejamus autoru darbus legālās tīmekḷa vietnēs un samazinot nelegālo tīmekḷa vietṇu skaitu, sabiedrība arvien vairāk izvēēēsies legālas vietnes, pat gadỉjumā, ja tās būs maksas.

Arī pētījumā "Eiropas pilsoṇi un intelektuālais īpašums - uztvere, informētība un rīcība" $83 \%$ aptaujāto iedzìvotāju atbildēja, ka digitālo saturu labprātāk izvēlas iegūt, izmantojot likumīgus un oficiāli atzītus pakalpojumus, nevis lietojot nelikumīgus lïdzeklıs [18].

Nacionālajos tiesību aktos nepieciešams noteikt stingrāku atbildību par autortiesību pārkāpumiem, un kritiku neiztur arguments, ka sabiedrība nezina, kas ir autortiesības un kuros gadījumos tās tiek pārkāptas. Liela dạı to zina. Turklāt soda sistēma ir neefektīva, jo nenodrošina spēju cīnīties ar intelektuālā īpašuma pirātismu.

G̣enerāladvokāts Macejs Špunara Eiropas Savienības Tiesas lietā Nr. C-610/15 Stichting Brein pret Ziggo BV, XS4ALL Internet BV savos secinājumos norāda: ja attiecīgais turētājs pats neveic autora monopolam raksturīgu darbību (piemēram, "izziṇošanu" sabiedrībai), šis pārkāpums var tikt izdarìts tikai netieši. Tā kā atbildība par šādiem pārkāpumiem Eiropas Savienības tiesību līmenī nav saskaņota, tai jābūt skaidri paredzētai valsts tiesībās. Valstu tiesām jāpārbauda, vai to valsts tiesībās šāda atbildība ir paredzēta. Ja var tikt konstatēta tādas vienādranga tīkla indeksācijas vietnes turētāja atbildība, kurā bez autortiesību ìpašnieku piekrišanas tiek kopīgoti aizsargāti darbi, tad jāuzskata, ka šis turētājs pēc analog̣ijas ar personu, kas pati tieši izdara autortiesību pārkāpumu, izmanto to interneta pievienojuma nodrošinātāju pakalpojumus, kuru klienti kopīgo datnes šajā tìklā.

Šo konstatējumu neatspēko tas, ka tāda vietne kā TPB varētu tikt iekḷauta izmitināšanas pakalpojumu sniedzēju kategorijā, kuru atbildība par glabāto informāciju ir izslēgta saskaṇā ar Direktīvas 2000/31 14. panta 1. punktu. Faktiski šĩ imunitāte ir nosacìta. Tā tiek piešḳirta tikai gadījumā, ja pakalpojumu sniedzējs nav zinājis par glabātās informācijas nelikumīgo raksturu vai par darbību, kas tiek veikta, izmantojot šo informāciju, un ar nosacỉjumu, ka pēc brīdinājuma par šo nelikumību saṇemšanas viņš rīkojas ātri, lai attiecīgo informāciju izṇemtu vai padarītu nepieejamu. Ja pakalpojumu sniedzējs (starpnieks) neizpilda šos nosacījumus, proti, ja tas ir zinājis par glabātās informācijas nelikumību, bet nav rīkojies, lai to izṇemtu vai padaritu nepieejamu, tad tas var tikt atzìts par netieši atbildīgu par šìs informācijas publiskošanu [13].

Arī lietotājam jābūt atbildībai, izmantojot nelegālu saturu, tādēl nepieciešams noteikt interneta pieslēguma nodrošinātāja līdzdalību nelegāla satura lietotāju ierobežošanā. Patlaban galvenokārt tiek izmeklēti gadỉjumi, ja bez licences tiek lietotas datorprogrammas, bet daudz mazāk par audiovizuālu darbu lejupielādi vai augšupielādi. N̦emot vērā Latvijas valsts pagātnes mantojumu, kad "māksla piederēja tautai", iespējams, ka, 
uzliekot atbildību pašam lietotājam, mazinātos nelegāla satura lietošana. Tādēl nepieciešams pastiprināt interneta pievienojuma nodrošinātāja sadarbību ar tiesībsargājošajām institūcijām.

Biedrība "Par legālu saturu!" 2018. gada 25. aprīlī publicēja 2017. gadā veiktā pētījuma "Nelegālās maksas TV apraides apjoms un interneta satura lietošanas paradumi Latvijā" rezultātus, kuri parādỉja, ka 2017. gadā no kopumā 707000 mājsaimniecību, kurās ir pieejama televīzija, legālos pakalpojumus izmantoja ap 630000 mājsaimniecību, bet nelegālos pievienojumus - ap 80000 mājsaimniecību. Savukārt 2015. gadā mājsaimniecību skaits, kurās izmantoja nelegālo maksas televīziju operatoru pakalpojumus, bija par $20 \%$ lielāks, tātad 100000 mājsaimniecību. Pētījums atklāja autortiesību aizsardzības problēmas Latvijā - $60 \%$ aptaujāto atzina, ka sods, ja patērētājs tiek pieḳerts nelegāli lietojam saturu internetā, ir ḷoti mazs vai diezgan mazs, turklāt $56 \%$ uzskata, ka varbūtība tikt piek̦ertam, lietojot saturu internetā nelegāli, ir ḷti maza vai diezgan maza [21].

Nenoliedzami, adekvātai autortiesību aizsardzībai, tāpat kā jebkura cita īpašuma aizsardzībai, kas ir viens no mūsdienu civilizācijas tiesību pamatprincipiem, jābūt pietiekami augstā lìmenī.

\section{Secinājumi un priekšlikumi}

Digitalizācijas laikmets autortiesību aizsardzības sistēmā radījis daudz jautājumu un strīdu, kuru risināšanā kā starpnieks tiek izmantota tiesa. Lai gan Latvijas tiesu praksē ir visai maz strīdu par autortiesību aizsardzību digitālajā vidē, tomēr Eiropas Savienības Tiesas ikdienā arvien vairāk nākas risināt dažādus autortiesību aizsardzības strīdus, kas attiecas uz intelektuālo īpašumu digitālajā vidē. Pēdējo gadu laikā palielinās to cilvēku skaits, kas izmanto internetu, līdz ar to aktualizèjas autoru darbu aizsardzỉbas problēmas.

Eiropas Savienības Intelektuālā īpašuma biroja veiktā aptauja liecina, ka likumīgu avotu lietošana ir palielinājusies, tāpat kā informētība par tiešsaistes satura likumību, tomēr ir pieaugusi neskaidrība par to, kas veido likumīgu vai nelikumīgu piedāvājumu. $24 \%$ aptaujāto eiropiešu šaubijās, vai lietotais avots bijis likumīgs vai ne (salïdzinot ar 2013. gada pētījumu, šis rādītājs palielinājies par pieciem punktiem); $4 \%$ aptaujāto eiropiešu norādīja, ka ir pētijjuši, lai pārbaudītu, vai avots bija likumīgs vai ne (attiecīgi pieaugums par diviem punktiem) [18].

Aptaujas rezultāti skaidri iezīmē problēmu - l̦oti liels ir autordarbu piedāvājums digitālajā vidē, un patērētājs nevar būt pārliecināts par avota izmantošanas tiesiskumu. Šo problēmu nevar risināt tikai ar resoriskiem paṇēmieniem, liekot pārkāpējam maksāt soda naudu.

Pat izmantojot populāro YouTube, patērētājs nevar būt pārliecināts, vai lietotais saturs ir legāls vai nelegāls. Mūsdienu tehnologijas lauj ar programmu, piemēram, Soundhound, palīdzību noteikt atskaņotās mūzikas autoru un izpildītāju, tātad jauno tehnolog̣iju laikmetā pieejami daudz un dažādi tehniskie risinājumi, lai mazinātu neskaidrības par izmantotā autordarba tiesiskumu. 
2010. gadā Lielbritānijā tika pieņemts likums "Par digitālo ekonomiku" (The Digital Economy Act) [3], kura mērḳis bija mazināt autortiesību pārkāpumus tiešsaitē, palielināt sodus par autortiesību pārkāpumiem, kā arī paplašināt publiskā patapinājuma tiesības netradicionāliem grāmatu formātiem. Saskaṇā ar šo likumu interneta pakalpojumu nodrošinātāju pienākums ir paziṇot lietotājiem, ka no viṇu IP adreses notikusi prettiesiska piekḷuve ar autortiesībām aizsargātiem darbiem.

N̦emot vērā, ka Latvijā ḷoti daudzi izmanto nelegālu saturu, būtu lietderīgi Latvijas tiesiskajā regulējumā ieviest stingrāku atbildību par satura lietošanu un noteikt arī atbildību interneta pakalpojuma nodrošinātājiem par līdzdalību nelegāla satura izplatī̌sanā.

Priekšlikumi:

- Papildināt Elektronisko sakaru likuma 19. pantu (Elektronisko sakaru komersanta pienākumi) ar atsevišķu punktu, izsakot to šādā redakcijā:

"Konstatējot, ka no lietotāja IP adreses notikusi nelegāla satura lejupielāde un augšupielāde, elektronisko sakaru komersantam ir pienākums nosūtīt lietotājam paziņojumu, ka no viṇa IP adreses notikusi prettiesiska piekḷuve ar autortiesībām aizsargātiem darbiem. Atkārtota paziņojuma nosūtī̌sanas gadījumā, ja tas noticis gada laikā, elektronisko sakaru komersantam ir pienākums informēt Valsts policiju par konstatēto pārkāpumu."

- Papildināt Latvijas Administratīvo pārkāpumu kodeksa $155 .{ }^{8}$ pantu ar otro daḷu, izsakot to šādā redakcijā:

"Par autortiesību vai blakustiesību pārkāpšanu, kas pārkāptas atkārtoti gada laikā, uzliek naudas sodu divkāršā apmērā no pirmajā daḷā noteiktā."

Digitalizācijas laikmetā patērētājam digitālajā vidē tomēr ir daudz vieglāk piekḷūt nelegālam saturam nekā atrast legālu, jo ir pieejamas daudzas interneta vietnes, kurās tiek piedāvāts noskatīities audiovizuālu darbu bez maksas. Kã jau iepriekš tika minēts, Latvijas Kultūras ministrija sadarbībā ar Eiropas Savienības Intelektuālā īpašuma biroju ir izveidojusi portālu "Nem droši!", kurā tiek piedāvātas legālas iespējas internetā skatìties filmas, klausìties mūziku, lasīt grāmatas vai spēlēt videospēles. Šãdā veidā tiek popularizēts legāls saturs un izglītots patērētājs, lai izveidotu sapratni par autoratlīdzību. Būtiski ir izglïtot sabiedrību par autortiesībām, nevis tikai ieviest soda sankcijas, tādēl izglītojoši pasākumi var veicināt sabiedrības izpratni par autortiesību sistēmu. 


\section{Legal Protection of Authors' Rights in the Digital Environment}

\section{Abstract}

Technological innovation has created new opportunities for sharing cultural heritage and scientific creativity of different nations. With the development of technology, the public is increasingly being given the opportunity to use intellectual property, but not always the author receives remuneration for the work used, because it is easy to use some work without paying for it.

The development of the digital environment also raised shortcomings of the copyright regulation, the prevention of which plays an important role not only in Latvia, but also worldwide. In May 2015, the European Union adopted the Digital Single Market Strategy, which aims to find solutions to reduce differences between national copyright regimes and provide users with greater online access to works.

The aim of the research is to analyse legal protection of authors' work in the digital environment and give advice on how to decrease the usage of illegal content and discourage the public from infringing copyright in the digital environment.

Document analysis has mainly been used to conduct the research. International and national laws were used to analyse the legal framework; so were the judgments of the European Union court on copyright infringement in the digital environment. The authors of the study on copyright issues - professor Ingrīda Veiksa, a professor at the School of Business Administration Turiba, and commissioner Ginter H. Ettinger, responsible for digital economy and public affairs, as well as Rihards Gulbis, counsellor of the Supreme Court of the Republic of Latvia.

Keywords: copyright, internet, digital environment, copyright infringement, author's rights.

\section{Avoti un literatūra}

\section{Tiesību akti}

1. Apvienoto Nāciju Organizācijas Vispārējā cilvēktiesību deklarācija: stājās spēkā 10.12.1948. Latvijas Republikas Tiesïbsargs. Iegūts no: http://www.tiesibsargs.lv/lv/pages/tiesibu-akti/anodokumenti/ano-vispareja-cilvektiesibu-deklaracija [sk. 11.04.2018.].

2. Autortiesību likums: Latvijas Republikas likums: stājās spēkā 11.05.2000. Latvijas Vêstnesis. Nr.148/150(2059/2061), 27.04.2000. Konsolidētā redakcijā iegūts no: https://likumi.lv/doc. php?id=5138 [sk. 13.05.2018.].

3. Bernes konvencija par literatūras un mākslas darbu aizsardzību: pieṇemta 09.09.1886. Latvijas Vēstnesis. 29, 21.02.2003. Konsolidētā redakcijā iegūts no: https:/likumi.lv/ta/lv/starptautiskieligumi/id/5 [sk. 22.03.2018.]. 
4. Latvijas Republikas Satversme: LV likums: pieṇemts 15.02.1922. un spēkā no 07.11.1922. Likumu un noteikumu krājums. 12, 1922.; Latvijas Vēstnesis. 43, 01.07.1993.; Latvijas Republikas Saeimas un Ministru Kabineta Ziṇotājs. 6, 2004.

5. Par intelektuālā īpašuma tiesību aizsardzības un nodrošināšanas pamatnostādnēm 2015.2020. gadam: Ministru kabineta 01.04.2015. rīkojums Nr. 169. Latvijas Vēstnesis. 67(5385), 07.04.2015.

6. Par Marakešas līgumu par Pasaules Tirdzniecības organizācijas izveidošanu: Latvijas Republikas likums: stājās spēkā 29.12.1998. Latvijas Vēstnesis. 387(1448), 29.12.1998.

7. Par vispasaules intelektuālā īpašuma organizācijas (WIPO) līgumu par izpildījumu un fonogrammām: stājās spēkā 17.02.2000. Latvijas Vēstnesis. 53/54(1964/1965), 17.02.2000. Konsolidētā redakcijā iegūts no: https://likumi.lv/ta/id/1335-par-vispasaules-intelektuala-ipasuma-organizacijas-wipo-ligumu-par-izpildijumu-un-fonogrammam [sk. 22.03.2018.].

8. Priekšlikums Eiropas Parlamenta un Padomes Direktīva par autortiesībām digitālajā vienotajā tirgū. Iegūts no: https:/eur-lex.europa.eu/legal-content/LV/TXT/?uri=CELEX\%3A52016PC0593 [sk. 18.04.2018.].

9. The Digital Economy Act 2010 and online copyright infringement. Legislation.gov.uk. Iegūts no: http://www.legislation.gov.uk/ukpga/2010/24/crossheading/online-infringement-of-copyright [sk. 18.03.2018.].

10. The Statute of Anne: Lielbritānijas likums: pieṇemts 1710. gadā. The History of Copyright. Iegūts no: https://www.copyrighthistory.com/anne.html [sk. 20.03.2018.].

\section{Tiesu prakse}

11. Eiropas Savienības Tiesas 2014. gada 27. marta spriedums lietā C-314/12 UPC Telekabel Wien GmbH pret Constantin Film Verleih GmbH, Wega Filmproduktionsgesellschaft mbH. Eiropas Savienības Tiesa. 2014. Iegūts no: http://curia.europa.eu/juris/document/document. jsf?docid=149924\&doclang=LV [sk. 20.03.2018.].

12. Eiropas Savienības Tiesas 2016. gada 8. septembra spriedums lietā C-160/15 GS Media BV pret Sanoma Media Netherlands BV, Playboy Enterprises Interntional Inc., Britt Geertruida Dekker. EUR-Lex [ES tiesību akti un publikācijas]. 2016. Iegūts no: https://eur-lex.europa.eu/legal-content/LV/TXT/?uri=CELEX\%3A62015CJ0160 [sk. 25.03.2018.].

13. Eiropas Savienības Tiesas 2017. gada 14. jūnija spriedums lietā C-610/15 Stichting Brein pret Ziggo BV, XS4ALL Internet BV. Iegūts no: https://eur-lex.europa.eu/legal-content/LV/ ALL/?uri=CELEX\%3A62015CJ0610 [sk. 18.02.2018.].

14. G̦enerāladvokāta Melhiora Vatelē secinājumi 2016. gada 7. aprīlī Eiropas Savienības Tiesas lietā C-160/15 GS Media BV pret Sanoma Media Netherlands BV, Playboy Enterprises International Inc., Britt Geertruida Dekker. EUR-Lex [ES tiesību akti un publikācijas]. Iegūts no: https://eur-lex. europa.eu/legal-content/LV/TXT/HTML/?uri=CELEX:62015CC0160\&from=LV [sk. 20.04.2018.].

15. Latvijas Republikas Augstākās tiesas Senāta Krimināllietu departamenta 2006. gada 18. aprīḷa lēmums lietā SKK-213/06. www.at.gov.lv/files/uploads/files/docs/summaries/.../atceltie\%20spriedumi-2008.doc

\section{Literatūra}

16. Aizaksons, V. 2012. Stìvs Džobss. Rīga: Zvaigzne ABC.

17. Eiropas digitālais vienotais tirgus. Eiropas Komisija. 2015. Iegūts no: http://http://europa.eu/ rapid/press-release_IP-15-4919_lv.htm [sk. 23.03.2018.]. 
18. Eiropas pilsoṇi un intelektuālais īpašums - uztvere, informētība un rīcība. EUIPO [Eiropas Savienības Intelektuālā īpašuma birojs]. 2017. Iegūts no: https://euipo.europa.eu/tunnel-web/ secure/webdav/guest/document_library/observatory/documents/IPContributionStudy/2017/ executiveSummary/executive_summary_lv.pdf [sk. 18.04.2018.].

19. Grudulis, M. 2006. Ievads autortiesībās. Latvijas Vēstnesis.

20. Gulbis, R. Meklējot interešu līdzsvaru digitālajā vidē: ES autortiesību noteikumu pārskatīšana. Jurista Vārds. 2(804), 04.01.2014.

21. Par legālu saturu. Biedrība "Par legālu saturu". 2016. Iegūts no: http://parlegalusaturu.lv/lv/ par-biedribu/ [sk. 18.04.2018.].

22. Par autortiesību pārkāpumiem pārtraukta divu Latvijā populāru tīmekḷu vietṇu darbība. Latvijas Valsts policija. 2018. Iegūts no: http://www.vp.gov.lv/?relid=16253 [sk. 18.04.2018.].

23. Pētījums "Mūzikas patēriṇa indekss, 2016. gada 2. ceturksnis". 2016. Latvijas Izpildìtāju un producentu apvienība. Iegūts no: http://www.laipa.org/lat/jaunumi/391-nakama-pasaules-limenamuzikas-superzvaigzne-varetu-nakt-no-latvijas [sk. 20.03.2018.].

24. Reda, J. EU copyright reform / expansion. Julia Reda. 2018. Iegūts no: https://juliareda.eu/eucopyright-reform/ [sk. 20.04.2018.].

25. The effect of piracy website blocking on consumer behavior. Tehnology policy institute. 2015. Iegūts no: https://techpolicyinstitute.org/wp-content/uploads/2015/06/the-effect-of-piracywebsite-b-2007716.pdf [sk. 18.04.2018.].

26. Veikša, I. Komunikācija internetā: saikne uz autordarbu kā izṇēmums no autortiesību aizsardzības. No: Communication in the global village: interests and influences. XVIII starptautiskās zinātniskās konferences rakstu krājums. Biznesa augstskola “Turība”. Iegūts no: http:// www.turiba.lv/lv/bizness-zinatne/petnieciba/publikacijas/konferencu-rakstu-krajumi/164/ [sk. 20.04.2018.]. 


\title{
Sporta jēdziens un tā attiecināšana uz prāta spēlēm
}

\author{
Dr. iur. Jel̦ena Alfejeva \\ Rìgas Stradiña universitāte, Juridiskā fakultāte, Latvija \\ alfejeva@inbox.lv
}

\section{Kopsavilkums}

Rakstā aplūkots sporta jēdziens un sporta tiesiskais regulējums dažādos tiesību aktos, kā arī analizētas neskaidrības šajā jautājumā.

Ar jēdzienu "sports" apzīmē gan fiziskas aktivitātes, gan arī prāta spēles, kurās cilvēki piedalās, lai saglabātu un uzlabotu fizisko un garīgo veselību. Tomēr sporta jēdziena tiesiskajā regulējumā ir dažas neskaidrības, jo Latvijas un Eiropas Savienības (ES) tiesību aktos sports netiek skaidri definēts.

Sporta jēdziena pareiza noteikšana ir svarīga, piemēram, lai saņemtu atbrīvojumu no pievienotās vērtības nodokḷa maksāšanas (sk. Eiropas Savienības Tiesas spriedumu lietā C-90/16, 2017) [12].

Šis publikācijas mērḳis ir aktualizēt sporta jēedziena noteikšanas problēmas, izpētīt atbilstīgās tiesību normas, kā arī aplūkot šo normu piemērošanas praksi un, pamatojoties uz izpētīto, noteikt problēmu risināšanas iespējas.

Pētot šos jautājumus, tika izmantotas gan vispārējās zinātniskās, gan speciālās juridiskās izzinas metodes. Pētỉjuma materiāls bija dažādi dokumenti, atziṇas, viedokḷi, Latvijas un Eiropas Savienības tiesību normas, kā arī novērošanas rezultāti. Tiesību normu tulkošanai tika izmantota gramatiskā, vēsturiskā, sistēmiskā un teleologiiskā metode.

Atslēgvārdi: sports, tiesību jēdziens, tiesību jēdziena definēšana.

\section{levads}

Vēsturiski sabiedrībā sportu saprata tikai kā darbības, kas saistītas ar fiziskām aktivitātēm. Sporta sacensības tika pielīdzinātas izklaides pasākumiem. Tomēr laika gaitā attīstījās sporta loma un pieauga tã sociālā nozīme sabiedrībā. Sportošana tika atbalstìta ne tikai ar nolūku pilnveidot cilvēku fiziskās prasmes un nodrošināt izklaidi, bet arī dot 
iespējas sociālās mijiedarbības prasmju veicināšanai un gādāt par profesionālajā sportā neiesaistītu indivīdu fiziskās un garīgās formas uzlabošanu. Pēc sabiedrības domām, tieši šīs sporta funkcijas patlaban ir visvairāk atbalstāmas.

Laika gaitā mainījies arī priekšstats par sporta nesaraujamu saistību ar fizisku darbību, un sporta veidu sarakstā iekḷautas arī tās aktivitātes, kas nav tieši saistītas ar fizisko slodzi, piemēram, šahs, dambrete un bridžs.

Attīstoties vairāku sporta aktivitāšu tiesiskajai reglamentācijai, arī sporta jēdziens tika iekḷauts tiesību aktos. Tomēr sports kā tiesību jēdziens joprojām nav viennozīmīgi definēts. Vairumā gadijumu tiesību aktos nav iekḷauta sporta definīcija, paḷaujoties uz vispārējo izpratni par šā vārda nozīmi.

N̦emot vērā iepriekšminēto, tiesību piemērotājiem šo jautājumu vajadzēja risināt, balstoties uz vispārējo izpratni par sportu un tiesiskā regulējuma mērḳiem.

Interesants piemērs sporta definēšanas problēmai ir apskatîts Eiropas Savienības Tiesas spriedumā lietā C-90/16 (turpmāk - EST spriedums lietā C-90/16) [12]. Šis prejudiciālais nolēmums tapa, lai interpretētu tiesību normas, kas izriet no Padomes Direktīvas 2006/112/EK (2006. gada 28. novembris) par kopējo pievienotās vērtības nodokḷa sistēmu, saistībā ar atbrīvojumiem no pievienotās vērtības nodokḷa bridža pasākumiem (turpmāk Direktīva 2006/112) [3]. Risinot jēdziena "sports" satura jautājumu, Eiropas Savienības Tiesa šajā spriedumā mēgināja abstrahēties no sporta vispārējās lomas vērtēšanas sabiedrībā un saglabāt sākotnējo priekšstatu par sportu kā darbībām, kas saistītas ar fiziskām aktivitātēm, turklāt atzīstot, ka fiziskajam elementam jābūt būtiskam.

Tādējādi šā raksta mērkis ir identificēt jēdziena "sports" problēmas tiesiskajā regulējumā un piemērošanā juridiskajā praksē. Lai veiktu šo pētijjumu, tika izmantotas vispārējās zinātniskās un speciālās juridiskās metodes: analīzes un sintēzes metode, indukcijas un dedukcijas, kā arī vēsturiskā metode. Pētījuma materiāls bija dažādi dokumenti, literatūra un tiesu prakse. Tika veikta Latvijas tiesību normu un ES tiesību aktu analīze, kā arī izmantoti novērošanas rezultāti.

\section{Sporta jēdziena definēšana}

Risinot jautājumu par kāda jēdziena definēšanu, vispārēji ir atzīts, ka vispirms jāatklāj tā saturs, nosaucot raksturīgās pazīmes. Jēdzienu definē, lai tas pildītu konkrētu funkciju. Tiesību dokumentos jēdzienu definīcijas iekḷauj ar mērḳi izvairīties no nevajadzīgas garu skaidrojumu atkārtošanas dokumenta tekstā. Definīcijas dod jēdzieniem, kas dokumentā tiek vairākkārt atkārtoti un lietoti îpaši un kam tiesību sistēmā ir īpaša izpratne. Tādējādi dažādos dokumentos var būt vārdiski vienādi apzīmēti dažādi šã dokumenta nolūkiem izmantojamie jēdzieni.

Tiesību akti tiek izstrādāti dažādu nozaru vajadzībām. Katrā nozarē lieto tai raksturīgos jēdzienus, kuri izteikti ar terminiem. Tiesību aktā terminus skaidro, ja terminā izteiktajam jēdzienam ir ìpaša nozīme tajā nozarē, ko tiesību akts regulē, vai lai konkretizētu terminā izteiktā jēdziena izpratnes robežas [14]. 
Terminam jābūt viennozīmīgam, tādēl tas visā tiesību akta tekstā jālieto vienā nozīmē. Kaut gan to lieto vienā nozīmē viena tiesību akta tekstā, citā tiesību aktā to var darīt atšksirīgi.

Jēdzienam "sports" starptautiskā līmenī nav unificētas definīcijas. Ministru komitejas ieteikumā dalïbvalstīm Nr. R(92) 13 REV "Pārskatītā Eiropas Sporta harta" (pieṇemts Ministru komitejā 1992. gada 24. septembrī 480. sanāksmē un pārskatìts 2001. gada 16. maijā 752. sanāksmē) ir sniegta jēdziena "sports" definīcija [5].

Šã dokumenta otrajā pantā ir noteikts, ka Sporta hartā ar vārdu "sports" tiek apzīmēti gadỉjuma vai organizētie fizisko aktivitāšu veidi, kas vērsti uz fiziskās un garīgās formas uzlabošanu un kas rada sociālās attiecības vai kuru dēl tiek gūti rezultāti visu līmeṇu sacensībās.

Tādējādi hartā sniegtajā sporta definīcijā, kurā sports sākotnēji saistīts ar fiziskajām aktivitātēm, papildus norādìta arī garīgā stāvokḷa uzlabošana, uzsverot arī sociālās lomas svarīgumu. Fiziska aktivitāte ir jebkura kustība, tāpēc Sporta hartā sports primāri saistīts ar cilvēka kustībām, nenorādot to nepieciešamo īpatsvaru, tomēr piebilstot, ka fiziskām aktivitātēm jābūt saistītām ar fiziskās un garīgās formas uzlabošanu un sociālo attiecību radīšanu. Turklāt hartas preambulā teikts, ka sports ir sociāla un kultūras darbība, kuras pamatā ir brīvprātīga izvēle, kas veicina saziṇu starp Eiropas valstīm un pilsoṇiem, un tai ir būtiska loma Eiropas Padomes funkciju îstenošanā (6. punkts) [5].

Savukārt Eiropas Komisijas dokumentā "Baltā grāmata par sportu" teikts, ka šajā dokumentā tiek lietota Eiropas Padomes izstrādātā jēdziena "sports" definīcija, kas norāda uz vēlēšanos unificēt jēdziena "sports" uztveršanu, lietojot to dažādos Eiropas starptautiskajos dokumentos [1].

Ar prejudiciāliem nolēmumiem Eiropas Savienības Tiesa pēc būtības atzinusi, ka, nnemot vērā Eiropas Savienības mērķus, ES tiesības attiecas uz sportu tikai saimnieciskās darbības aspektā Līguma par Eiropas Savienības darbību izpratnē (sk., piemēram, 1995. gada 15. decembra sprieduma lietā C-415/93 Bosman, Recueil 73. punktu [8]; 2000. gada 11. aprīla sprieduma apvienotajās lietās C-51/96 un C-191/97 Deliège, Recueil 41. punktu [9]; 2000. gada 13. aprīḷa sprieduma lietā C-176/96 Lehtonen un Castors Braine, Recueil 32. punktu [10]; 2006. gada 18. jūlija spriedumu lietā C-519/04 David Meca-Medina un Igor Majcen pret Eiropas Kopienu Komisiju [11]).

Vērtējot sportu Eiropas Kopienas kompetences kopsakarā ar Eiropas Kopienas līguma 149. un turpmāko pantu piemērošanu [2], var secināt, ka šā līguma darbības laikā Eiropas Kopiena, pievēršoties sporta jomai, aplūkoja vien ierobežotu jautājumu loku, t. i., sports tika skatìts kā algots darbs vai maksas pakalpojumu sniegšana, kā tas daḷeeji vai pilnībā ir profesionālajā sportā.

Savukārt kopš 2009. gada Līgums par Eiropas Savienības darbību (turpmāk - LESD) paredz, ka ES kompetencē ir veikt darbības, lai atbalstītu, koordinētu vai papildinātu dalïbvalstu rīcību, kas Eiropas līmenī skar arī izglìiību, arodmācības, jaunatni un sportu (6. panta e apakšpunkts) [1]. 
Jāpiebilst, ka ES nav vispārējas reglamentējošas kompetences attiecībā uz dalībvalstīm - tai ir tikai kompetence un pilnvaras, kas tai piešḳirtas ar ES tiesību aktiem. LESD 12. sadaḷa sākas ar 165. pantu (iepriekš Eiropas Kopienas līguma 149. pants), kurā paredzēta ES rīcības nostāja, tostarp sporta jomā, proti, šajā pantā teikts, ka ES rīcības mērḳis sporta jomā ir attīstìt Eiropas dimensiju sportā, veicinot taisnīgumu un atklātîbu sporta sacensībās un sadarbību starp struktūrām, kas ir atbildīgas par sportu, kā arī sargājot sportistu, jo īpaši jaunāko sportistu, fizisko un morālo integritāti. Minētajā līguma pantā arī paredzēts, ka ES dalïbvalstis - gan kopīgi, gan katra atseviški - izglìtības un sporta jomā sekmē sadarbỉbu ar trešajām valstīm un kompetentām starptautiskām organizācijām, jo īpaši - ar Eiropas Padomi.

Šie apgalvojumi ES pamatdokumentā nav tieši izmantojami ES tiesību normu teleologiskai interpretācijai, piemēram, vērtējot atbrīvojuma no pievienotās vērtības nodokḷa piešķiršanu, tomēr tie ir vērā n̦emami, vērtējot ES intereses sportā, no tā pastarpināti izsecinot par ES iedomājamo sporta saturu.

Sabiedrībā sportam ir svarīga sociālā loma, tāpēc sporta sasaiste ar saimniecisko darbību nebūtu tik tieši vērtējama, kā to norāda Eiropas Savienības Tiesa, bet sports būtu jāapskata arī no cilvēktiesību viedokḷa, kā arī saistībā ar tā sociālo lomu ab initio. Protams, ES tiesību akti nekonkurē ar sporta "iekšējām tiesībām”, atḷaujot tām nosacītu autonomiju. Tomēr, balstoties uz sporta sociālo nozīmi, nosakot ES kompetenci, ES institūcijām, galvenokārt Eiropas Savienības Tiesai un Eiropas Komisijai, ir jāizstrādā likumīgas sporta pārvaldības koncepcija, tās robežas nosakot plašāk par sporta kā saimnieciskās darbības pārvaldīšanu, lai gan šai koncepcijai Lìgumā par Eiropas Savienības darbību nav skaidra tiesiskā pamata [18].

Nav apšaubāms, ka sporta īpašais raksturs ir noteikts ar LESD, tāpēc ir nepieciešama skaidra ES institūciju nostāja, kā šo jomu pārvaldīt. Taču šo uzdevumu izpilde nav iespējama, ja jēdzienam "sports" netiek dots skaidrs un nepārprotams saturs, kuru izmantot gan politikā, gan tiesībās.

Šajā ziṇā nav veiksmīgs Eiropas Savienības Tiesas spriedums lietā C-90/16, ka tāda aktivitāte kā sporta bridžs nav sports. Lietā sniegt prejudiciālu nolēmumu lūdza Lielbritānijas tiesa, izskatot strīdu starp Anglijas Bridža savienību un nodokḷu administrāciju par pievienotās vērtības nodokḷa uzlikšanu ieejas maksai (maksa par dalību turnīrā), ko Anglijas Bridža savienība iekasē par tās organizētajiem sporta bridža turnīriem [7].

Interpretācijai šajā lietā tika pakḷautas Direktīvas 2006/112/EK normas, kurās paredzēts piešķirt atbrīvojumu ar sportu cieši saistītajam pakalpojumam, neatklājot jēdziena "sports" saturu [3]. Tā Direktīvas 2006/112 132. panta 1. punkta m apakšpunktā paredzēts, ka dalībvalstis atbrīvo no nodokḷa konkrētus pakalpojumus, kas cieši saistīti ar sportu vai fizisko audzināšanu un ko bezpel̦nas organizācijas sniedz personām, kas piedalās sporta vai fiziskās audzināšanas pasākumos [3].

Iepazīstoties ar iesniegtajiem materiāliem, Eiropas Savienības Tiesa atzina, ka sporta bridža spēlē ir nepieciešama atmiņa, logiskā, stratēgiskā un konceptuālā domāšana un šì nodarbe ir labvēlīga to personu garīgajai un fiziskajai veselībai, kuras to veic 
regulāri, tomēr to pielīdzināja izklaidei, nevis sportam. Šādi spriežot, netika ṇemts vērā, ka Starptautiskā Olimpiskā komiteja prāta spēles uzskata par sportu, jo tā atzīst bridža, šaha u. c. federācijas, kas pārstāv šos sporta veidus.

Formāli konstatējot, ka tikusi veikta sistēmiskā un teleologiskā tiesību normu interpretācija, Eiropas Savienības Tiesa pamatojumam izraudzījās iepriekš izdarītos judikatūras secinājumus, kas izdarīti pirms LESD pieņemšanas. Tiesa skaidroja, ka Direktīvas 2006/112 interpretētās normas neattiecas uz visām ar izklaidi un atpūtu saistītām darbībām, pat ja tās ir labas fiziskajai un garīgajai veselībai. Tiesa arī norādīja, ka bridža sacensības varētu atzìt par kultūras pakalpojumiem, kuriem atbilstīgi Direktīvas 2006/112 132. panta 1. punkta $n$ apakšpunktam arī paredzēts atbrīvojums no pievienotās vērtības nodokḷa [3].

Tādējādi, sekojot Direktīvas 2006/112 regulējumam, Eiropas Savienības Tiesa noškīira sporta un kultūras pasākumus. Šis iedalījums gan ir nosacìts, jo Eiropas Sporta hartas preambulas 6. punktā teikts, ka sports ir sociāla un kultūras darbība. Nošķirot sporta un kultūras pasākumus, var nonākt pretrunā ar Eiropas Padomes sniegto sporta kā kultūras elementa lomas novērtēšanu.

Eiropas Padomes interneta vietnē norādìts, ka visās kultūrās sports ir universāls elements. To atzīstot, tiek arī apliecināts, ka ar sportu jauniešiem tiek piedāvātas sociālās mijiedarbības iespējas, lai attīstītu zināšanas, prasmes un attieksmi - nepieciešamo viṇu pilnvērtīgai līdzdalībai pilsoniskajā sabiedrībā, sasaistot kultūru un sportu ar cilvēktiesībām.

Var secināt, ka Eiropas Savienības Tiesas jēdziena "sports" interpretācijai nav tāda pamatojuma, kuru varētu rast no ES vai starptautisku institūciju izteikumiem, secinājumiem vai regulējumiem šajā jomā.

\section{Latvijas sporta tiesiskā reglamentācija}

Sporta definīcija Latvijas Republikas Sporta likumā līdzinās definīcijai Eiropas Komisijas Baltajā grāmatā un aptver arī prāta sporta veidus. Saskaṇā ar šā likuma 1. panta 10. punktu sports ir visu veidu individuālas vai organizētas aktivitātes fiziskās un garīgās veselības saglabāšanai un uzlabošanai, kā arī panākumu gūšanai sporta sacensībās [2].

Latvijas Republikā par sporta nozari atbildīgā valsts pārvaldes iestāde ir Izglìtības un zinātnes ministrija. Tã uzrauga biedrībai "Latvijas Sporta federāciju padome” (turpmāk LSFP) delegeèto valsts pārvaldes uzdevumu izpildi. LSFP ir sporta nozarē patstāvīga Latvijas Republikas normatīvajos aktos noteiktajā kārtībā atzīto 90 sporta federāciju apvienība, kura atbilstīgi Sporta likumam pārstāv un īsteno to kopīgās intereses, tostarp sadala valsts budžeta finansējumu sportam.

Sporta likuma 10. ${ }^{1}$ pantā paredzēti kritēriji un kārtība sporta federācijas atzī̌sanai. Starp kritērijiem, piemēram, ir darbības mērḳis, t. i., attiecīgā sporta veida (attiecīgo sporta veidu) vai darbības jomas attīstīšana valstī un sporta sacensību organizēšana. Starp Sporta likumā noteiktajā kārtībā atzītajām sporta federācijām ir Latvijas Šaha federācija, Latvijas 
Bridža federācija un Latvijas Dambretes savienība. Izvērtējot šo federāciju pārstāvētos sporta veidus, var secināt, ka tieši tie nav saistīti ar fiziskajām aktivitātēm, bet veicina cilvēka garīgo veselību, kā arī pilda svarīgu sociālo lomu.

Savukārt Pievienotās vērtības nodokḷa likumā sports minēts tikai nolūkā noteikt ar to saistìta pakalpojuma sniegšanas vietu (20. pants), kā arī brīdi, kad ziṇas par nodokli jānorāda nodokḷa deklarācijā (124. pants) [4]. N̦emot vērā, ka likumā nav paredzēti speciāli tieši ar sportu saistīti atbrīvojumi, līdz šim nav bijusi problēma definēt, kas ir sports vai sporta pasākums saistībā ar pievienotās vērtības nodokli.

\section{Sporta jēdziena attiecināšana uz prāta spēlēm} veidiem.

Vispārējā starptautiskajā praksē šahs, dambrete un bridžs tiek saistīti ar sporta

Bridžu var uzskatīt par sabiedrībai vispieejamāko sporta veidu. Lai ar to nodarbotos, nav ierobežojumu ne vecuma, ne arī invaliditātes dēḷ. N̦emot vērā plašo pieejamību, tas var būt arī visvairāk saistîts ar saimniecisko darbību: ar daudzu indivīdu piedalǐšanos sporta bridža pasākumos, kas organizēti pēc sporta sacensību principiem, un par dalību tajos parasti tiek iekasēta dalības (ieejas) maksa. Primārais maksas iekasēšanas mērkis parasti ir sacensību organizēšanas izdevumu segšana.

Bridžs ir spēle. Tas tāpat kā vairākas citas spēles, ṇemot vērā to vēsturisko izcelsmi, tika pieskaitìts sportam. Bridžā izmanto kārtis, taču tam nav lielas nozīmes, jo varētu izmantot jebkurus noteiktā skaita apzīmējumus, bet izvēli par labu kārtīm noteikusi tradīcija un ērtums, turklāt tās jau tiek lietotas citās kāršu spēlēs. Tomēr bridžs kardināli atškiras no citām kāršu spēlēm, jo veiksmes elements bridža sacensībās nav lielāks kā jebkurā klasiskajā sporta veidā. Visiem bridža sacensību dalïbniekiem ir viens un tas pats kāršu sadalījums, tādējādi uzvarēs tas, kurš vislabāk pratīs rīkoties ar savu kāršu kombināciju un piel̦aus vismazāk kḷūdu. Bridžs ir vienīgā kāršu spēle, kuru uzskata par olimpisko sporta veidu, pamatojoties uz 1998. gada Olimpiskās komitejas lēmumu. Tā kā bridžs ir pāra spēle, tas attīsta komunikācijas un mijiedarbības prasmes, kā arī citas svarīgas iemaṇas. Bridža sociālo nozīmīgumu veido arī tas, ka bridžs l̦auj saglabāt un uzlabot cilvēka garīgo veselību, attīstīt prātu un logisko domāšanu, turklāt dalībniekiem nav vecuma ierobežojumu [16].

1998. gadā Starptautiskā Olimpiskā komiteja nolēma sporta bridžu starptautiski atzīt, klasificējot to kā sporta veidu. Šobrīd tam ir olimpiskais statuss, kas nozīmē, ka tiks izteikts piedāvājums bridžu iekḷaut olimpisko spẹlu programmā. Jau šobrīd notiek starptautiskie bridža turnīri, un tajos sasniegtie rezultāti ir tieši atkarīgi no dalībnieku prasmēm un treniṇos ieguldītā darba. Lai sacenstos sporta bridžā, jāpieliek ievērojamas intelektuālās pūles un nepieciešams daudz trenēties.

Taču pretēji šeit minētajiem bridža spēlētāju pozitīvajiem ieguvumiem EST spriedumā lietā C-90/16 tika noteikts, ka bridžs nav sporta veids, jo fiziskais elements tajā ir neliels. Spriedums pamatots ar to, ka sports ir saimnieciska darbïba, un vērtējums tika izdarīts no šāda skatpunkta, nepieḷaujot plaši tulkot sporta veidiem piemērojamo 
atbrīvojumu saturu. Šāda pieeja būtu attaisnojama, uzlūkojot sportu kā izklaidi, kas saistìta ar profesionālu sportistu un tiem pielīdzināmo pasākumu skatīšanos. Savukārt, ja tiek spriests par indivīdu, kas nav profesionāli sportisti, iesaistî̌anos aktivitātēs, kuras uzlabo viṇu fizisko un garīgo veselību, arī atbrīvojuma no pievienotās vērtības nodokḷa mērḳis būtu jāvērtē atbilstīgi šādu pasākumu sociālajai lomai, t. i., piešḳirot tiem atbrīvojumu no šì nodokḷa.

Pareizs ir generāladvokāta Maceja Špunara viedoklis lietā C-90/16. Viṇš uzskata, ka starp pazīmēm, kurām noteikti jāpiemīt, lai darbība atbilstu apzīmējumam "sports" Direktīvas 2006/112/EK izpratnē, fiziskais elements nav nepieciešams un šajā ziṇā sporta bridžs ir sports [7].

\section{Secinājumi}

Vēsturiski par sportu dēvēja tikai ar fiziskajām aktivitātēm saistītas darbības nolūkā attīstīt fiziskās prasmes, taču šobrīd sportu saista ar veselỉbas, arī garīgās veselības, uzlabošanu, kā arī akcentē tā sociālo nozīmi, kas, no sabiedrības viedokḷa raugoties, ir galvenokārt atbalstāma sporta funkcija.

Tiesību piemērotājiem vajadzēja risināt jautājumu par jēdziena "sports" saturu, balstoties uz vispārējo izpratni par sportu un tiesiskā regulējuma mērḳiem, bet šã risinājuma rezultāts šobrīd nav viennozìmīgs.

Latvijā tiesiskais regulējums aptver visus nepieciešamos sporta elementus, ņemot vērā arī sporta sociālo lomu un tā attīstības mērḳus.

Svarīgi ir pievērsties un tiesiski noteikt jēdziena "sports" saturu, turklāt tas būtu jādara visā ES. Jāveic arī tiesiskās darbības, kas mainītu Eiropas Savienības Tiesas praksi jēdziena "sports" definēšanā.

Lai novērstu šìs problēmas tiesību normu piemērošanā, svarīgi izprast, kas ir sports. Tādēl nepieciešams veikt grozījumus starptautiskajos dokumentos un tiesību aktos. Sports ir dažādu veidu individuālas vai organizētas aktivitātes fiziskās un garīgās veselības saglabāšanai un uzlabošanai, kā arī panākumu gūšanai sporta sacensībās. Lai izteiktu konkrētos priekšlikumus par izmain̄ām ES tiesību aktos, detalizētāk jāanalizē tiesību aktu struktūra.

\section{Definition of "Sport" and Its Extension to Mind Games}

\section{Abstract}

The article is devoted to the concept of sport, which is related to the ambiguous regulation in various legal acts. 
The term "sport" refers to both physical activity and mental games that are performed to preserve and improve the physical and mental health of a person. However, from the point of view of the legal framework, there may be some ambiguity with the concept of sport, as the legislation in Latvia and the RES do not have a clear definition for it.

The correct definition of the concept of sport is important in several respects, including under the exemption from value added tax (see judgment of the Court of Justice of the European Union in Case C-90/16).

The aim of the article is to update the problems of determining the concept of sport, to study the legal norms that apply to it, as well as to review the practice of applying these norms, based on which problems of solving the problem can be identified.

The methods of general scientific as well as special legal research are used in the development - the method of analysis and synthesis, methods of scientific induction and deduction, the comparative method, as well as the method of observation. The basis of the research is the observance of various documents, opinions and legal norms in both the law of Latvia and the European Union, as well as observation.

The grammatical, historical, systemic and teleological methods are used to translate legal norms.

Keywords: sport, law institute, law institute's definitions.

\section{Avoti un literatūra}

\section{Tiesību akti}

1. Baltā grāmata par sportu: Eiropas Parlamenta 2008. gada 8. maija rezolūcija par Balto grāmatu par sportu 2007/2261(INI). ES publikäcijas. 2008. Iegüts no: https://publications.europa. eu/lv/publication-detail/-/publication/ee80bb3e-f92f-4ef8-9d34-c5689133fofe/language-lv [sk. 12.05.2018.].

2. Līguma par Eiropas Savienību un Līguma par Eiropas Savienības darbību konsolidētās versijas. Eiropas Savienības Oficiālais Vēstnesis. C326, 26.10.2012. Iegūts no: https://eur-lex.europa.eu/ legal-content/LV/TXT/?uri=celex\%3A12012E\%2FTXT [sk. 11.05.2018.].

3. Padomes Direktĩva 2006/112/EK par kopējo pievienotās vērtîbas nodokḷa sistēmu (2006. gada 28. novembris): Eiropas Savienības Padomes Direktīva. Eiropas Savienības Oficiālais Vēstnesis. L347, 11.12.2006., 1-118. Iegūts no: https://eur-lex.europa.eu/legal-content/LV/TXT/ ELI/?eliuri=eli:dir:2006:112:oj [sk. 11.05.2018.].

4. Pievienotās vērtības nodokḷa likums: Latvijas Republikas likums. Latvijas Vēstnesis. 197(4800), 14.12.2012.

5. Recommendation No. R(92) 13 rev of the Committee of Ministers to member states on the revised European sports charter (adopted by the Committee of ministers on 24 september 1992 at the $480^{\text {th }}$ meeting of the ministers' deputies and revised at their $752^{\text {nd }}$ meeting on 16 may 2001). Council of Europe Committee of Ministers. Iegūts no: https://rm.coe.int/16804c9dbb [sk. 10.04.2018.].

6. Sporta likums: Latvijas Republikas likums. Latvijas Vēstnesis. 165(2740), 13.11.2002.; Ziṇotājs. 23, 12.12.2002. 


\section{Tiesu prakse}

7. Eiropas Savienības Tiesa: G̦enerāladvokāta Maceja Špunara secinājumi, sniegti 2017. gada 15. jūnijā, lieta C-90/16 The English Bridge Union Limited pret Commissioners for Her Majesty's Revenue E Customs. Iegūts no: http://eur-lex.europa.eu/legal-content/LV/ TXT/?uri=CELEX:62016CC0090\#t-ECR_62016CC0090_LV_01-E0032 [sk. 10.04.2018.].

8. Eiropas Savienības Tiesas 1995. gada 15. decembra spriedums lietā C-415/93 Bosman, Recueil, 1-4921. EUR-Lex. Iegūts no: https://eur-lex.europa.eu/legal-content/EN/TXT/?qid=15359549 03478\&uri=CELEX:61993CJ0415 [sk. 10.04.2018.].

9. Eiropas Savienības Tiesas 2000. gada 11. aprīla spriedums apvienotajā lietā C-51/96 un C-191/97 Deliège, Recueil, 1-2549. EUR-Lex. Iegūts no: https://eur-lex.europa.eu/legal-content/EN/TXT /?qid=1535955753848\&uri=CELEX:61996CJ0051 [sk. 11.04.2018.].

10. Eiropas Savienības Tiesas 2000. gada 13. aprīla spriedums lietā C-176/96 Lehtonen un Castors Braine, Recueil, 1-2681. EUR-Lex. Iegūts no: https://eur-lex.europa.eu/legal-content/EN/TXT/ ?qid=1535955333975\&uri=CELEX:61996CJ0176 [sk. 13.05.2018.].

11. Eiropas Savienības Tiesas 2006. gada 18. jūlija spriedums lietā C-519/04 David Meca-Medina un Igor Majcen pret Eiropas Kopienu Komisiju, ECR 2006, 1-6991. EUR-Lex. Iegūts no: https:// eur-lex.europa.eu/legal-content/EN/TXT/?qid=1535955498501\&uri=CELEX:62004CJ0519 [sk. 12.05.2018.].

12. Eiropas Savienības Tiesas (ceturtās palātas) 2017. gada 26. oktobra spriedums lietā C-90/16 The English Bridge Union Limited pret Commissioners for Her Majesty's Revenue E Customs. 2017. Eiropas Savienības tiesību akti un publikācijas. Iegūts no: https://eur-lex.europa.eu/legalcontent/LV/TXT/?uri=CELEX\%3A62016CJ0090 [sk. 11.04.2018.].

\section{Literatūra}

13. Kusiņš, G. 1999. Normatīvo aktu jaunrade. No: Mūsdienu tiesību teorijas atziṇas. Rīga: Tiesu namu aǵentūra.

14. SportAccord: Starptautiskā sporta federāciju asociācija. 2018. Iegūts no: http://www.sportaccord. com [sk. 10.04.2018.].

15. Starptautiskā Olimpiskā komiteja. 2018. Iegūts no: https://www.olympic.org/ [sk. 10.04.2018.].

16. Vyas, R. and Nalwaya, N. 2015. Sports as a CSR Initiative: Empowering the Youth (06 May, 2015). Youth Empowerment (Book): Himanshu Publication. Iegūts no: https://ssrn.com/abstract=2728598 [sk. 11.05.2018].

17. Weatherill, S. 2011. EU Sports Law: The Effect of the Lisbon Treaty (25 January, 2011). Oxford Legal Studies Research Paper. 3/2011. Iegūts no: https://ssrn.com/abstract=1747916 [sk. 10.04.2018.]. 


\title{
Zvērināta advokāta orderis kā tiesību elements
}

\author{
Linda Reisa \\ Rīgas Stradiña universitāte, Juridiskā fakultāte \\ Tiesību zinātñu katedra, Latvija \\ linda.reisa@advokatam.lv
}

\section{Kopsavilkums}

Judikatūrā ir noteikts, ka zvērinātam advokātam kā tiesu sistēmai piederīgas profesijas pārstāvim juridiskās palīdzības sniegšanai pietiek ar vienkāršu rakstveida pilnvaru, kurai papildus jāiesniedz orderis, un ka zvērinātu advokātu orderis apliecina ne vien pašu pilnvarojumu, bet arī tiesu sistēmai piederīgās personas - zvērināta advokāta ipašo statusu.

Tomēr profesionāḷu vidū jau tiek diskutēts par atteikšanos no ordera kā advokāta lietvedības dokumenta, tāpēc nav saprotams, ko judikatūra atrisina praksē, nosakot, ka civilprocesā zvērināta advokāta pilnvarojumu apliecina pilnvara un orderis. Tieši pretēji, lìdz šim nebija kāzusu par to, kad un kāpēc jāiesniedz orderis. Savukārt tiesa, iespējams, šobrīd ir paudusi neuzticību advokātu institūtam, nepamatoti norādot, ka advokātu var identificēt pēc izsniegtā ordera, nevis publiskiem aktiem, tādējādi faktiski neatzīstot to par tiesu sistēmai piederīgu personu.

Atslēgvārdi: advokāts, orderis, pilnvara.

\section{levads}

Pirmās Latvijas brīvvalsts laika zvērināts advokāts Jūlijs Šmits ir teicis:

"Advokatūra, izpildīdama noteiktas tiesu organizācijas funkcijas un būdama par tiesu iekārtas nepieciešamu sastāvdaḷu, līdz ar to izpilda svarīgu uzdevumu. To nevajag aizmirst, kad novērtē advokatūras lomu valstī, kad spriež par advokatūras reorganizāciju un kad sabiedrībā pārrunā advokātu tikumus un netikumus." [9, 3]

Saskan̄ā ar Latvijas Republikas Advokatūras likuma (turpmāk - arī Advokatūras likums) 2. pantu advokatūra ir tiesiskas valsts justīcijas neatṇemama sastāvdaḷa. Savukārt šā likuma 5. pantā paredzēts, ka zvērināti advokāti (turpmāk - arī advokāti) ir tiesu 
sistēmai piederīgas personas lietu vešanai jebkurā Latvijas Republikas tiesā un pirmstiesas izmeklēšanas iestādē pēc pušu, apsūdzēto un citu lietas dalībnieku (klientu) izvēles un viṇu uzdevumā [6].

Ievērojot iepriekš minēto, kā arī Advokatūras likuma 48. panta otro punktu, likumdevējs ir noteicis, ka, sniedzot juridisko palīdzību, zvērināts advokāts ir tiesīgs vākt pierādījumus, pieprasìt visus juridiskās palīdzības sniegšanai nepieciešamos dokumentus no valsts un pašvaldību institūcijām, kā arī no citām iestādēm, organizācijām un uzṇēmējsabiedrībām (uzṇēmumiem), kurām likumā noteiktajā kārtībā un gadījumos jāizsniedz šie dokumenti vai to noraksti un zvērinātam advokātam jānodrošina iespēja iepazīties ar tiem. Saskaṇā ar Advokatūras likuma 6., 10. un 48. pantu advokātam ir piešḳirtas tiesības piekḷūt ierobežotas pieejamības informācijai, kas nepieciešama pilnvērtīgai un savlaicīgai klienta likumisko interešu aizsardzībai jebkurā procesa stadijā [6].

Neatkarīgi no tā, vai zvērinātu advokātu nolīdzis indivīds, korporācija vai valsts, viṇa būtība ir pārstāvēt klientu un būt viṇam par uzticamu padomdevēju, būt par trešo pušu respektētu profesionāli un neaizstājamu dalībnieku taisnīgas tiesas spriešanā. Ietverot visus šos elementus, zvērināts advokāts, kurš patiesi rīkojas sava klienta interesēs un aizstāv klienta tiesības, pilda arī zvērināta advokāta amatpienākumus sabiedrībā, t. i., rīkojas, lai novērstu un atturētu no konflikta, nodrošinātu, lai konfliktsituācijas tiktu risinātas saskaṇā ar atzītiem civiltiesību, valsts tiesību vai krimināltiesību principiem un ar pienācīgu tiesību un interešu ievērošanu, veicinātu tiesību pilnveidošanu un aizstāvētu brīvību, taisnīgumu un likuma varu [4].

Satversmē un Civilprocesa likumā būtiski atšḳiras jēdziena "advokāts" saturs. Satversmē tiek pieḷauts terminu "advokāts" interpretēt paplašināti, ar to saprotot ne tikai tās personas, kas ir noteiktas Advokatūras likuma 4. pantā, bet arī citus juridisko pakalpojumu sniedzējus. Proti, Satversmes 92. panta ceturtajā teikumā ir noteikts, ka "ikvienam ir tiesības uz advokāta palīdzību". Juridiskais jēdziens "advokāts", kas ietverts Satversmes 92. pantā, jātulko paplašināti, ar to saprotot personas tiesības saṇemt juridisko palīdzību, brīvi izvēloties aizstāvi vai pārstāvi dažādās lietās no iespējami plašāka kvalificētu juristu loka un atsevišşos likumā noteiktos gadījumos arī no citu personu loka [8].

Latvijas Republikas Satversmes tiesas spriedumā lietā Nr. 2003-04-01 teikts:

\footnotetext{
“Tiesības uz advokātu Satversmes 92. panta izpratnē, pirmkārt, ietver tiesības uz kvalificētu juridisko palīdzību un, otrkārt, valsts pienākumu šādu palīdzību sniegt personām, kuras pašas nevar to atḷauties. [..] Šāds no Satversmes 92. panta izrietošais ikvienas personas tiesību uz advokāta palīdzību saturs nav izsmeḷošs, tas var tikt paplašināts, bet ne ierobežots." [7]
}

Latvijas Republikas Augstākās tiesas Civillietu departaments, paplašinātā sastāvā skatot civillietas Nr. C29539915 materiālus (SKC-1788/2016), savā lēmumā (turpmāk arī - lēmums) ir norādījis, ka zvērinātu advokātu orderis apliecina ne vien pašu pilnvarojumu, bet arī tiesu sistēmai piederīgās personas - zvērināta advokāta - ipašo statusu, un ka likums papildus neaizliedz zvērinātam advokātam, tāpat kā jebkurai citai fiziskai 
personai, rīcības brīvību noslēgt pilnvarojuma līgumu Civillikuma 2289. panta izpratnē un darboties saskaṇā ar to arī ārpus viṇa profesionālās darbības ietvariem, ko regulē Advokatūras likuma normas. Tomēr tiesai visos gadỉjumos jāspēj pārliecināties, vai konkrētajā lietā attiecīgais pilnvarnieks darbojas privātpersonas vai tiesu sistēmai piederīgas personas - zvērināta advokāta - statusā [11].

Šeit minētajam nevar piekrist, jo advokāta statusu un piederību kolēgijai apliecina Zvērinātu advokātu padome atbilstoši Latvijas Republikas Advokatūras likuma noteikumiem, šie lēmumi ir publiski, tātad ieguvuši publiska akta spēku. Orderis nav pamats apliecinājumam, ka persona ir zvērināts advokāts, tas vien norāda uz sniedzamās juridiskās palīdzības apjomu un institūciju, tātad faktiski orderis jāsaista tikai ar lietas vešanas kārtību vai apjomu, nevis personas piederību Zvērinātu advokātu kolēgijai.

Latvijas Republikas Augstākā tiesa (turpāk - AT) jau ir skatījusi jautājumu par ordera nozīmi advokāta pārstāvībā civilprocesā, tomēr joprojām nav vienotas nostājas šajā jautājumā. To apliecina ne tikai AT Civillietu departamenta tiesnešu I. Gardas, V. Jonikāna, V. Maksimova un Z. Pètersones izteiktās atsevišķās domas par 2016. gada 17. jūnija lēmumu civillietā Nr. C29539915 [10], tādējādi apstiprinot, ka radītā judikatūra nav viennozīmīga, bet arī fakts, ka tiesas pilnvarojuma apjomu advokātam tulko dažādi.

Pēc autores domām, ordera institūtu būtu nepieciešams vērtēt civiltiesību nozares tvērumā.

Šã raksta mērḳis ir izpētìt ordera kā likumā noteiktā zvērināta advokāta lietvedības dokumenta jēgu un lietošanas robežas. Mērķa sasniegšanai tika izmantotas vairākas metodes: analīze, lai noskaidrotu pētāmā objekta struktūru; logiiskā metode, ar kuras palīdzību iegūtie rezultāti tika novērtēti; interpretācijas metode, lai analizētu tiesību normas. Pētījuma bāze ir dažādu zinātnieku un speciālistu atziṇas un viedokḷi, tiesu prakse, kā arī izpētē gūtie secinājumi.

\section{Rezultāti}

Saskaṇā ar Civilprocesa likuma 82. panta ceturto daḷu lietas dalībnieku piedalīšanās civilprocesā neatṇem viṇiem tiesības uzaicināt savā lietā advokātu juridiskās palīdzības sniegšanai. Šajā gadījumā advokāta pilnvaru apjoms noteikts atbilstīgi Civilprocesa likuma 86. pantam, un paskaidrojumus par lietas būtību vin,š nesniedz [3]. Savukārt saskaṇā ar Advokatūras likuma 48. ${ }^{1}$ pantu zvērināta advokāta pilnvarojumu un tā apjomu, kā arī tiesības izpildīt Advokatūras likuma 48. pantā noteiktos uzdevumus apliecina orderis, kura paraugu apstiprina Latvijas Zvērinātu advokātu padome [6].

Advokatūras likuma 48. pantā likumdevējs precīzi ir uzskaitīis tos uzdevumus, kurus advokāts ir tiesīgs izpildīt, pamatojoties uz paša izrakstītu orderi, proti:

- aizstāvēt un pārstāvēt personu, kura lūgusi juridisko palīdzību, tās tiesības un likumiskās intereses visās tiesās, prokuratūrās un pirmstiesas izmeklēšanas iestādēs, kā arī visās valsts un pašvaldỉbu institūcijās, kā arī citās iestādēs, organizācijās un uzṇēmējsabiedrībās (uzṇēmumos); 
- vākt pierādījumus, arī pieprasot visus juridiskās palīdzības sniegšanai nepieciešamos dokumentus no valsts un pašvaldību institūcijām, kā arī citām iestādēm, organizācijām un uzṇēmējsabiedrībām (uzṇēmumiem), kurām likumā noteiktajā kārtībā un gadījumos ir jāizsniedz šie dokumenti vai to noraksti un jānodrošina advokātam iespēja iepazīties ar tiem, kā arī likumā noteiktajā kārtībā juridiskās palīdzības sniegšanai saṇemt lietpratēju atzinumu jautājumos, kuri prasa attiecīgas zināšanas;

- iepazīties ar valsts un pašvaldību institūciju, tiesu, prokuratūru un pirmstiesas izmeklēšanas iestāžu normatīvajiem un individuālajiem aktiem, ar citu informāciju, kas saistīta ar juridiskās palīdzības sniegšanu, kā arī saṇemt šo dokumentu norakstus [6].

Tātad gadījumā, ja advokāts ar klientu vienojas par plašāku pilnvarojuma apjomu, klients zvērinātam advokātam izsniedz pilnvaru, kas saskaṇā ar Civilprocesa likuma 86. pantu [3] un Civillikuma 2289. pantu [2] ietver arī Advokatūras likuma 48. pantā [6] minētās tiesības. Šobrīd tiesa, nostiprinot judikatūrā pienākumu advokātam pilnvarojuma apjomu pierādìt gan ar pilnvaru, gan ar orderi, nepamatoti un mākslīgi dublē pilnvarojuma apjomu.

Var secināt, ka tiesa ar lēmumu centusies noteikt zvērināta advokāta statusa atšḳiršanu no citām personām, kas var būt par pilnvarnieku lietā, tomēr tas nav izdevies, un lēmumā sniegtajai argumentācijai nevar piekrist šādu apsvērumu dēḷ:

- orderis apliecina advokāta tiesības sniegt klientam juridisko palīdzību, taču to nevar uzskatìt par pilnvaru Civillikuma izpratnē, jo to nav izsniedzis klients, bet advokāts sev izrakstīis pats;

- orderī netiek iekḷauts pilnvarojuma apjoms, un tas nepiešḳir advokātam Civilprocesa likumā noteiktās pārstāvja tiesības, bet apliecina faktu, ka advokāts sniedz juridisko palīdzību apjomā, kas noteikts Advokatūras likuma 48. pantā.

Var uzskatìt, ka orderis pēc būtības ir speciāls uzdevums ierobežotu darbību veikšanai un tam nevajag klienta izsniegtu rakstveida vai mutvārdu pilnvarojumu. Piemēram, uz ordera pamata advokāts var pieprasìt informāciju par savu klientu, savukārt juristam, kas nav advokāts, šāda iespēja ir tikai uz notariāli apliecinātas pilnvaras pamata. Šì, iespējams, arī ir vienīgā nianse, kas ḷāvusi orderim kā tikai advokāta lietvedības dokumentam saglabāties līdz mūsdienām.

Tiesa lēmumā nepareizi ir tulkojusi Civilprocesa likuma 85. panta trešo daḷu, proti, saskaṇā ar minēto normu advokāta pilnvarojumu juridiskās palīdzības sniegšanai apliecina orderis, ja advokāts uzstājas kā puses pilnvarots pārstāvis, un šo pilnvarojumu apliecina ar rakstveida pilnvaru. Tulkojot gramatiski, redzams, ka likumdevējs ir paredzējis divas iespējas, kā advokāts pārstāv personu civilprocesā. Likumdevējs nav noteicis, kuros gadījumos jāiesniedz abi dokumenti, kuros - pietiek tikai ar vienu. Taču šì norma nelıauj nešaubīgi uzskatīt, ka orderis ir pilnvarojumu apliecinošs dokuments.

Arī doktrīnā ir pausts viedoklis, ka ir atšķirīgas prasības, kurām jāatbilst pilnvarai pārstāvēt, ko realizē advokāts vai cita persona. Advokātam pietiek ar rakstveida pilnvaru $[15,307]$. 
N̦emot vērā iepriekšminēto, rodas vairāki jautājumi. Vai pirms šīs neviennozīmīgās judikatūras maiṇas personām tika nodarīi zaudējumi, vai tika konstatēts, ka advokāts savas tiesības un pienākumus pilda negodprātīgi? Vai tieši orderis ir tas dokuments, kas turpmāk ḷaus tiesām pārliecināties, ka advokāts pilnvarotāja vārdā uzdevumu veic godam? Vai lēmums ir sasniedzis judikatūras pamatprincipu mērḳi?

Atškiriībā no pilnvaras orderis civilprocesā tiek izmantots, lai nošķirtu gadijjumus, kuros advokāts pārstāv klientu, no gadijjumiem, kuros advokāts sniedz tikai juridisko palīdzību (vai kriminālprocesā - ir aizstāvis; administratīvo pārkāpumu lietvedībā - pilda vēl nenoteiktākus uzdevumus). Savukārt no Satversmes tiesas lietas Nr. 2014-12-01 stenogrammas var secināt, ka ordera jēga ir formāla - advokāta statusu apliecinoša; tas līdz šim ticis izmantots kā pamats nošḳiršanai, vai izdevumus par advokāta sniegto juridisko palīdzību ir jāatlīdzina lietā zaudējušai pusei.

Jāpiekrīt Satversmes tiesas tiesnesei S. Osipovai, kas norādījusi: ja advokāts ir atpazīstams, ir lēmums par advokāta uzṇemšanu Advokātu kolēgijā, ir amata zīmes, dati par viṇu ir publiski pieejami - tas viss liek domāt, ka paša advokāta noteiktas formas apliecinājums (orderis) savu jēgu zaudē. Šo pašu mērḳi (apliecināt advokāta statusu) iespējams sasniegt arī citā veidā - ar advokāta iesniegtu apliecinājumu tiesai, piemēram, ar amata nosaukumu pirms uzvārda, kā to dara prokurori, tiesneši, notāri, tiesu izpildītāii un citas tiesu sistēmai piederīgās personas. Turklāt ordera iesniegšana un esamība lietā pati par sevi neapliecina advokāta statusu. Piemēram, ja persona ir bijusi advokāts laikā, kad notikusi pirmā tiesas sēde, turpinot lietas dalïbnieka pārstāvību citās tiesas sēdēs šajā instancē, personai var būt lietā esošs izrakstīts orderis (arī kasācijas instancei adresēts, piemēram, ja lieta jau vienreiz kasācijas instancē ir tikusi izskatīta) pat tad, ja persona darbību advokatūrā ir apturējusi vai arī kolēgija to ir atskaitījusi vai izslēgusi. Citiem vārdiem sakot, ne jau orderis apliecina advokāta statusu, bet gan Latvijas Zvērinātu advokātu padomes lēmumi, kuri turklāt ir publiski, un tieši tie nosaka tiesības un pienākumus advokātam lietot amata simbolus (amata zīmi, talāru), kā arī īstenot advokāta tiesības juridiskās palīdzības sniegšanā un aizstāvībā [18].

Gadijumi, kas apliecina, ka orderis nepierāda advokāta statusu un tiesības pildīt likumā noteiktos pienākumus, jau ir konstatēti praksē. 2018. gada 1. februārī Zemgales apgabaltiesa apelācijas kārtībā skatīja krimināllietu pēc Tukuma rajona prokuratūras prokurores apelācijas protesta, kurā norādīts, ka pēc krimināllietas izskatīšanas pirmās instances tiesā tika konstatēts, ka aizstāvim lietas izskatišanas laikā pirmās instances tiesā saskaṇā ar Latvijas Zvērinātu advokātu padomes Disciplinārlietu komisijas lēmumu bijis aizliegts pildīt advokāta pienākumus. Tātad, kaut gan lietā bija zvērināta advokāta izrakstîts orderis, advokāts nebija tiesīgs veikt apsūdzētā aizstāvību [13].

Minētais apliecina, ka nepamatota ordera statusa tulkošana var novest pie sekām, kas aizskar personas likumā noteiktās tiesības gan uz tiesu, gan uz lietas izskatīšanu saprātīgā termiṇā. Šāda situācija tiesiskā valstī nav piel̦aujama un ir antikonstitucionāla.

Satversmes tiesa savulaik ir norādījusi, ka advokāta orderis ir publisks akts, kas apliecina advokāta juridiskās palīdzības sniegšanu [9], tomēr šāds apgalvojums ir pretējs 
tam, kas nodibināts Administratīvā procesa likuma 1. panta piektajā un sestajā dạ̦ā, proti, saskaņā ar šīm normām ārējais normatīvais akts ir Satversme, likumi, Ministru kabineta noteikumi un pašvaldību saistošie noteikumi, kā arī starptautiskie līgumi un Eiropas Savienības pamatlīgumi un uz to pamata izdotie normatīvie akti. Iekšějais normatīvais akts ir tiesību akts, kuru publisko tiesību subjekts izdevis ar mērḳi noteikt savas vai sev padotas institūcijas iekšējās darbības kārtību vai izskaidrot kāda ārējā normatīvā akta piemērošanas kārtību savā darbības jomā (instrukcija, ieteikums, nolikums u. c.), turklāt, kā izriet no šĩ paša normatīvā akta 16. panta pirmās daḷas, iekšējais normatìvais akts ir saistošs tam publisko tiesību subjektam, kas šo aktu izdevis, kã arī šim publisko tiesību subjektam padotajām institūcijām. Privātpersonām iekšējais normatīiais akts nav saistošs [1]. Tādējādi var uzskatīt, ka orderis kā advokāta lietvedībā esošs dokuments var tikt izmantots tikai tam mērḳim, kas noteikts Advokatūras likuma 48. pantā.

Arī Civilprocesa likuma 82. pantā būtu jādzēš atsauce, jo, ja advokāts nepārstāv personu procesā uz pilnvaras pamata, var secināt, ka tiesu sistēmai piederīgā persona sniedz personai tikai juridisko palīdzību, un, ja apstiprinās, ka advokāta tiesības nav ierobežotas vai izbeigtas saskaṇā ar Advokatūras likuma noteikumiem, tad nekāds papildu apliecinājums juridiskās palīdzības sniegšanai nebūtu nepieciešams.

Nevienā ārējā normatīvajā aktā nav noteikta ordera aizpildī̌sanas kārtība, sekas par tā neprecīzu vai nepareizu aizpildī̌̌anu. Ordera noformēšanas noteikumi ir ietverti Atzinumā par advokāta ordera saturu [14; 18], kas apstiprināts ar Latvijas Zvērinātu advokātu padomes 2010. gada 20. decembra lēmumu Nr. 278 - tātad ar iekšēju aktu. Šo iekšējo aktu apstiprinājusi AT 2017. gada 27. jūnija lēmumā lietā Nr. C32336415; SKC-1299/2017, skaidrojot, ka Latvijas Zvērinātu advokātu padomes izdots iekšējais normatīvais akts, kurā reglamentēta advokāta ordera noformēšanas kārtība, ir saistošs ikvienam advokātam. Tajā noteikto prasību ignorēšana pakḷauj apdraudējumam pārstāvamās personas tiesības uz taisnīgu tiesu un būtiski apgrūtina tiesas pienākumu pārliecināties par advokāta statusu un tiesībām veikt procesuālās darbības izpildi, kā arī rada pamatotas šaubas par advokāta profesionalitāti un spēju nodrošināt kvalitatīvu juridisko palīdzību [12].

Šeit minētais apliecina, ka ordera kā tiesību elementa jēgas nepareiza iztulkošana un piemērošana var būt bīstama.

Advokatūras likuma 48. ${ }^{1}$ pantā noteikts, ka Latvijas Zvērinātu advokātu padome apstiprina ordera paraugu, nedodot tiesības Latvijas Zvērinātu advokātu padomei izdot ārēju normatīvo aktu, kas noteiktu ordera aizpildǐšanas kārtību. Tādējādi ordera veidlapa un tās aizpildīšanas kārtība uzskatāma par ieteikumu, nevis par regulējumu.

Jāvērtē arī speciālajā likumā, proti, Latvijas Republikas Advokatūras likuma 5. pantā, noteiktais, ka advokāti ir tiesu sistēmai piederīgas personas lietu vešanai jebkurā Latvijas Republikas tiesā un pirmstiesas izmeklēšanas iestādē pēc pušu, apsūdzēto un citu lietas dalībnieku (klientu) izvēles un viņu uzdevumā, kā arī likumā noteiktajos gadījumos tiesu priekšsēdētāju, pirmstiesas izmeklēšanas iestāžu vadītāju un Latvijas Zvērinātu advokātu padomes uzdevumā. Advokāti likuma noteiktajā kārtībā sniedz arī citu juridisko palīdzību [6]. No minētā arī izriet klienta un advokāta vienošanās autonomija. 
Savukārt, pievēršot uzmanību pilnvarojuma institūtam, AT Civillietu departamenta tiesneši pareizi norādijjuši, ka no Civilprocesa likuma izriet četri gadījumi, kuros advokāta statuss ir obligāts priekšnoteikums pilnvarojuma spēkā esībai vai īpašu tiesību izmantošanai.

1. Ja fiziskās personas pilnvara nav notariāli apliecināta. Saskaṇā ar Civilprocesa likuma 85. panta pirmo un trešo dal̦u fiziskā persona vienkāršu rakstveida pilnvaru, kas nav notariāli apliecināta, var izsniegt tikai advokātam.

2. Lietas vešanai kasācijas instances tiesā. Saskaṇā ar Civilprocesa likuma 82. panta sesto un septīto daḷu lietas kasācijas instances tiesā fiziskās personas ved pašas vai ar advokāta starpniecību, juridiskās personas - ar amatpersonu vai advokāta starpniecību.

3. Ja tiesas procesā uzvarējusī puse vēlas no zaudējušãs puses piedzìt izdevumus advokāta palīdzības samaksai (Civilprocesa likuma 44. panta pirmās daḷas 1. punkts; arī Augstākās tiesas Civillietu departamenta 2015. gada 28. augusta spriedums lietā Nr. C27130310; SKC-0187/2015).

Ja advokāts sniedz juridisko palīdzību saskaṇā ar Civilprocesa likuma 82. panta ceturto daḷu. Turklāt jānorāda, ka juridiskās palīdzības sniegšana šìs normas izpratnē nav "klasiskā" pārstāvība. Tas ir klienta dots uzdevums advokātam piedalīties tiesas procesā, savas procesuālās tiesības realizējot pašam prasītājam, atbildētājam vai trešajai personai, bet advokātam sniedzot juridiska rakstura padomus, uzdodot jautājumus citiem lietas dalïbniekiem un lieciniekiem un piedaloties tiesas debatēs. Tas nav pilnvarojums izpildìt visas (pilnvarā norādītās) procesuālās darbības lietas dalībnieka vietā un ir jānošķir no Civilprocesa likuma 82. panta otrajā daḷā, 83. pantā, 85. panta otrajā daḷa un 85. panta trešās daḷas otrajā teikumā minētā pilnvarojuma [10].

Latvijā tiek daudz runāts par advokāta procesa ieviešanu, tomēr, piemēram, šeit analizētā lēmuma pieṇemšana neveicina ne sadarbību starp tiesu un tiesai piederīgajām personām, ne sabiedrības uzticību tiesai.

Judikatūras grozišana, ja tās veikšanai nav objektīvu apstākḷu (grozījumu normatīvajos aktos u. c. iepriekšminēto apstākḷu), turklāt laikā, kad juristu vidū tiek spriests par atteikšanos no ordera advokāta lietvedībā gan tā arhaisma dẹl, gan nesaprotamās tā juridiskās dabas, izrietošo pienākumu un atbildības vai citām iestādēm saistošã spēka dēl, neveicina vienotu izpratni par tiesībām uz pārstāvību un tiesībām uz tiesu [18].

Jāuzsver, ka valsts ir veikusi tiesu sistēmas modernizēšanu, lēnām tiek ieviesta elektroniskā saziṇa tiesā, un arī iespējām pārliecināties par zvērināta advokāta statusu jāatbilst mūsdienu prasībām. Saskañā ar Advokatūras likuma 18. pantu Latvijas Zvērinātu advokātu kolēgija ir neatkarīga Latvijas zvērinātu advokātu profesionāla korporācija, kas apvieno visus Latvijā praktizējošos zvērinātus advokātus, tikai Latvijas Zvērinātu advokātu kolēgiijai ir šajā likumā noteiktās tiesības un pienākumi [6].

Var secināt, ka tikai Latvijas Zvērinātu advokātu kolẹgija var apliecināt, ka konkrētā persona ir zvērināts advokāts un tiesīgs uzn,emties normatīvajos aktos noteiktos pienākumus un ĩstenot tiesības. 
Vajag sākt diskusijas par to, kā nodrošināt personām, iestādēm un institūcijām iespēju elektroniski pārliecināties, vai persona, kas uzstājas kā zvērināts advokāts lietā, nav izslēgta no kolēgijas un vai tās darbība nav apturēta.

Situācijas var būt dažādas, un nav piel̦aujams, ka advokātu pienākums ir tādu darbību veikšana, ko neietver starp klientu un advokātu jau noslēgtā vienošanās, vienlaikus liedzot personai tiesības uz taisnīgu tiesu.

\section{Secinājumi}

1. Šobrīd var uzskatīt, ka tiek pārkāptas personas tiesības uz advokātu (vienošanās brīvība) un faktiski notiek iejaukšanās advokāta un klienta attiecībās.

2. Zvērināta advokāta statusu un piederību kolēgijai apliecina Zvērinātu advokātu padome atbilstoši Latvijas Republikas Advokatūras likuma noteikumiem, šādi lēmumi ir publiski, tātad ieguvuši publiska akta spēku. Orderis nav pamats apliecinājumam, ka persona ir zvērināts advokāts, tas vien norāda uz sniedzamās juridiskās palīdzības apjomu un institūciju, tātad orderis ir saistāms tikai ar lietas vešanas kārtību, nevis personas piederību Zvērinātu advokātu kolēgijai.

3. Orderis neapliecina advokāta pilnvarojumu civilprocesā tiesā, jo nav publisks akts, tā aizpildīšanas kārtībai nav ārēja normatīvā regulējuma, pieejams vien Zvērinātu advokātu padomes izdots "Atzinums par advokāta ordera saturu", kas nesniedz konkrētas norādes par dokumentā ierakstāmās informācijas apjomu. Likumdevējs nav sniedzis ordera definīciju, bet norādījis, ka tas dod eksluzīvas tiesības advokātam vākt pierādījumus, pieprasīt informāciju, iesniegt kasācijas sūdzību un îstenot aizstāvību. Minētais nav paplašināmi tulkojams, padarot orderi par zvērināta advokāta pilnvarojuma sastāvdaḷu. Orderi var uzskatīt par īpašu dokumentu to darbību veikšanai, kas noteiktas Advokatūras likuma 48. pantā. Savukārt to, vai advokāts uzstājas kā pilnvarotā persona tiesā, apliecina izdota pilnvara. Ja tās nav, būtu uzskatāms, ka zvērināts advokāts sniedz tikai juridisko palīdzību Civilprocesa likuma 82. pantā paredzētajā apjomā.

4. Civilprocesa likuma 85. panta trešã dạ̦a nav tulkojama paplašināti, proti, pilnvarojumu advokātam apliecina rakstveida pilnvara, kas izsniegta advokātam. Uz pilnvaras pamata zvērināts advokāts var gan pārstāvēt personu, gan sniegt juridisko palīdzību, savukārt uz ordera pamata šobrīd var sniegt tikai juridisko palīdzību. Nav pamata šādam duālismam. Orderis kā advokāta lietvedībā esošs dokuments var tikt izmantots tikai tam mērḳim, kas noteikts Advokatūras likuma 48. pantā. Arī atsauce Civilprocesa likuma 82. pantā būtu jādzēš, jo var secināt, ka gadījumā, ja advokāts procesā nepārstāv personu uz pilnvaras pamata, tiesu sistēmai piederīgā persona sniedz tikai juridisko palīdzību personai, un, ja apstiprinās, ka advokāta tiesības nav ierobežotas vai izbeigtas saskaṇā ar Advokatūras likuma noteikumiem, tad papildus kāds apliecinājums juridiskās palīdzības sniegšanai nav nepieciešams. 
5. Civilprocesa ietvaros jādiskutē par ordera lietderību un nepieciešamību vai tā turpmāko tiesisko statusu. Jāraisa diskusija par ordera aizstāšanu ar elektronisku iespēju personām un iestādēm pārliecināties par zvērināta advokāta tiesībām pildìt likumā noteiktos pienākumus un uzṇemties tiesības.

\section{Sworn Advocate's Retainer as Legal Element}

\section{Abstract}

Currently the case law states that a sworn advocate as a member of the judicial system should be given a simple written power of attorney, in addition to which a retainer is to be issued, and that the sworn advocate's retainer certifies not only the authorisation as such, but also the special nature of a person's belonging to the judicial system - sworn advocate - status.

There are now discussions among professionals about the abandonment of the retainer as a lawyer's record-keeping document. Thus, it is not clear what the case law solves in practice when determining that just a power of attorney and retainer together authorise a sworn advocate in a civil procedure. On the contrary, there have been no problems so far about when and why the retainer was to be served. The court, on the other hand, in the present situation may express a lack of confidence in the sworn advocate institution, unreasonably pointing out that a sworn advocate can be identified on the basis of a retainer issued, rather than by public law, and effectively denying it a person belonging to the judicial system.

Keywords: sworn advocate, retainer, power of attorney.

\section{Avoti un literatūra}

\section{Tiesību akti}

1. Administratīvā procesa likums: Latvijas Republikas likums: pieṇemts 25.10.2001. Latvijas Vèstnesis. 164, 14.11.2001.

2. Civillikums: Latvijas Republikas likums: pieñemts 28.01.1937. Valdības Vēstnesis. 46, 26.02.1937.

3. Civilprocesa likums: Latvijas Republikas likums: pieṇemts 14.10.1998. Latvijas Vēstnesis. 326/330, 03.11.1998.

4. Eiropas Advokāta profesijas pamatprincipu harta: pieṇemts 24.11.2006. CCBE. Iegūts no: https:// www.ccbe.eu/NTCdocument/ccbe_etikas_kodekss_15_1253625489.pdf [sk. 12.04.2018.].

5. Latvijas Republikas Satversme: Latvijas valsts likums: pieṇemts 15.02.1922. Latvijas Vēstnesis. 43, 01.07.1993.

6. Latvijas Republikas Advokatūras likums: Latvijas Republikas likums: pieṇemts 27.04.1993. Ziṇotājs. 28, 19.08.1993. 


\section{Tiesu prakse}

7. Latvijas Republikas Satversmes tiesas spriedums lietā Nr. 2003-04-01, 2003. gada 27. jūnijs. Latvijas Vēstnesis. 97(2862), 01.07.2003.

8. Latvijas Republikas Satversmes tiesas spriedums lietā Nr. 2003-08-01, 2003. gada 6. oktobris. Latvijas Vēstnesis. 138(2903), 07.10.2003.

9. Latvijas Republikas Satversmes tiesas spriedums lietā Nr. 2013-04-01, 2014. gada 7. februāris. Latvijas Vēstnesis. 30(5089), 11.02.2014.

10. Augstākās tiesas Civillietu departamenta tiesnešu Ināras Gardas, Valerijana Jonikāna, Valerija Maksimova un Zanes Pētersones atsevišḳās domas sakarā ar Augstākās tiesas Civillietu departamenta 2016. gada 17. jūnija lēmumu, lieta Nr. SKC-1788/2016.

11. Latvijas Republikas Augstākās tiesas Civillietu departamenta 2016. gada 17. jūnija lēmums, lieta Nr. SKC-1788/2016.

12. Latvijas Republikas Augstākās tiesas Civillietu departamenta 2017. gada 27. jūnija lēmums, lieta Nr. SKC 1299/2017.

13. Zemgales apgabaltiesas 2018. gada 1. februāra lēmums, lieta Nr. 11390009416.

\section{Literatūra}

14. Atzinums par advokāta ordera saturu. 2010. Latvijas Zvērinātu advokātu kolēgija. Iegūts no: http://www.advokatura.lv/uploads/A_Atzinums_par_advokata_ordera_saturu_2010_20_12_ Nr_278.doc [sk. 12.04.2018.].

15. Civilprocesa likuma komentāri. 2016. I daḷa. Aut. kol. prof. K. Torgāna zin. vad. Rīga: TNA.

16. Krastiṇa, I. 2008. Ėtiska neatkarība - mūsu zelts. Rīga: Biedrība "Latvietis".

17. Par Latvijas Zvērinātu advokātu padomes dokumentāciju (izraksts no padomes 1998. gada 28. novembra lēmuma Nr. 468). Latvijas Zvērinātu advokātu kolēgiija. Iegūts no: http://www. advokatura.lv/uploads/Par_padomes_dokumentaciju_Ordera_paraugs.doc [sk. 12.04.2018.].

18. Snipe, A., Šlitke, N. 2017. Viedoklis par advokāta ordera būtību un nozīmi. Jurista Vārds. 31.01.2017. Iegūts no: http://www.juristavards.lv/eseja/270076-viedoklis-par-advokata-orderabutibu-un-nozimi/ [sk. 12.04.2018.]. 


\title{
White-Collar Crime: Ukrainian Experience of Searching for Optimal Model of Criminal Liability
}

\author{
Dr. iur. Nataliya O. Gutorova \\ Poltava Law Institute of Yaroslav Mudry \\ National Law University, Ukraine \\ natalygutorova@gmail.com
}

\section{Abstract}

Author analyses quite a sensitive issue for society - white-collar crime in Ukraine, defining the optimally probable model of criminal liability. The white-collar shadow economy level is rather high in Ukraine $-45.96 \%$ of the GDP and correlates with the respective data of Nigeria. The author's approach can be related to two aspects: first, prevent excessive criminalization activities; second, effectively punish white-collar criminals.

Keywords: criminal liability, punishment, white-collar crime, restriction of liberty, confiscation of proceeds.

\section{Introduction}

The purpose of criminal law is to protect individuals and the entire society from socially dangerous acts. The method of such protection is recognition of acts like crimes, and establishment of criminal liability of persons who have committed them.

This liability is realised through state conviction, as well as criminal punishment and (or) other criminal legal measures that apply to the guilty persons. The main goal of criminal liability in a democratic society is to prevent new crimes that could be committed by both a person to whom this liability was applied and by other members of society.

Criminal law cannot and should not be the main means of resolving social conflicts, since its application is always connected with a significant restriction of the rights and freedoms of a perpetrator, as well as with collateral negative consequences for other persons and entire society. At the same time, the use of criminal law to regulate social relations, especially in the economic sphere, is often not effective. Therefore, in the science 
of criminal law, there is no doubt that criminal legal regulation of social relations is permissible only as an extreme, the last possible means, the ultimo ratio.

This conclusion is especially relevant in relation to white-collar crimes - corruption and other crimes committed by public officials, as well as economic and professional crimes. Usually, these crimes are committed by corruption, fraud, abuse of trust and negligent performance of official duties. These crimes cause significant harm, such as substantial property damage, harm to authority of public power, and in some cases, harm to life or human health.

Based on this, in determining the criminal liability for white-collar crimes, it is necessary to consider the significant harm they cause and the specifics of the personality of the white-collar offender. In contrast to the so-called common criminals, who commit, for example, thefts, robberies, bandit attacks, rape, etc., white-collar criminals in society have a positive reputation, care about their families, do not abuse alcohol or drugs. These personal characteristics of white-collar criminals should be taken into account when establishing criminal liability for the crimes they commit.

However, traditionally the criminal law is trying to use a unified approach to the application of criminal liability measures to both "common" criminals and whitecollar criminals. However, traditionally, the criminal legislation tries to use a unified approach when applying criminal liability measures to both "ordinary" criminals and "servants". We can observe obvious shortcomings of this approach in the post-Soviet space, including Ukraine. The law provides for a strict punishment for white-collar crimes, mainly in the form of long-term imprisonment. Courts often disagree with such a decision of the legislator, and will use many opportunities of the Ukrainian criminal law to mitigate punishment or use probation.

This difference between the criminal law and the practice of its application also increases the level of corruption risks in this area. As a result, criminal responsibility does not reach the goal of preventing white-collar crime, and sometimes even contributes to its growth.

Therefore, it is important to research the problems of optimisation of criminal responsibility for white-collar crimes.

\section{Aim}

The aim of this article is to research, using the experience of Ukraine, the possibility of developing an optimal model for criminal liability of persons who have committed white-collar crimes, and, in case of a positive result, the determination of its main components. This model should take into account personal characteristics of the subjects of these crimes, as well as provide for a complex of measures of criminal legal effect that will provide for the least possible restriction on the rights and freedoms of the guilty person and will be necessary and sufficient to achieve the goals of criminal responsibility. 
Nataliya O. Gutorova. White-Collar Crime: Ukrainian Experience of Searching for Optimal Model of Criminal Liability

\section{Materials and Methods}

This study is based on regulation acts, criminal legislation, Criminal Law Convention Council of Europe on Corruption (1999), Recommendation No. R (99) 22 of the Committee of Ministers to Member States concerning prison overcrowding and prison population inflation (Adopted by the Committee of Ministers on September 30, 1999 at the $681^{\text {st }}$ meeting of the Ministers' Deputies), the data of Corruption Perceptions Index 2017 from International Organisation Transparency International, the study of the Association of Chartered Certified Accountants "Emerging from the shadows. The shadow economy to 2025", the information of the Word Bank, the analysis of 450 criminal cases of white-collar crimes, according to which the courts of Ukraine had sentences (2009-2017), research works and opinions of progressive people in this field. Article is grounded on dialectical, comparative, analytic, synthetic and comprehensive research methods.

\section{Results and Discussion}

For the first time the theory of "white-collar crime" was formulated by the American criminologist Edwin Sutherland and represented in 1939 in a speech to the American Sociological Society. In his later article in 1940, the author substantiated the existence of white-collar criminality, which is a criminality of "upper or white-collar class, composed of respectable or at least respected business and professional men". This criminality is different from "crime in lower of persons of low socioeconomic status" [12, 1].

Sutherland proved that white-collar crime is a real crime, and it is very dangerous for society. He wrote: "The financial cost of white-collar crime is probably several times as great as the financial cost of all the crimes, which are customarily regarded as the 'crime problem."' The danger with this type of crime is not limited to causing financial damage.

The author states: "The financial loss from white-collar crime, great as it is, is less important than damage
to social relations. White-collar crimes violate trust and therefore, create distrust,
which lowers social morale and produces social disorganisation on a large scale. Other
crimes produce a relatively little effect on social institutions or social organisation."
$[12,4,5]$

Based on this, he believes that "a white-collar criminality in general terms will be also a description of the lower class. The respects in which the crimes of the two classes differ are the incidentals rather than the essentials of criminality. They differ principally in the implementation of the criminal laws which apply to them" $[12,7]$. The author comes to a conclusion that "the white-collar criminals are segregated administratively from others criminals, and largely as a consequence of this are not regarded as real criminals by themselves, the general public, or criminologists" $[12,8]$. 
The term "white-collar crime" is criminological and in criminal law has no precise definition. Dervan and Podgor in their article "White-collar Crime": Still Hazy After All These Years stated that there is no clear list of "white-collar crimes", although more than 75 years have passed since the appearance of this term. This is explained by the following: "Yet the term 'white-collar crime' was used initially as a sociological term and has been used more recently as a legal term tied to specific criminal offenses" [10, 766]. Ukrainian researchers Kamensky [8, 341-343] and Melnychuk [9, 197], based on the analysis of scientific literature, also note the lack of clarity in the criminal law definition of "whitecollar crime".

According to the U.S. Department of Justice, Dictionary of Criminal Justice Data Terminology, it is
"non-violent crime for financial gain committed by means of deception by persons whose occupational status is entrepreneurial, professional or semi-professional, and utilising their special occupational skills and opportunities; also, non-violent crime for financial gain utilising deception and committed by anyone having special technical and professional knowledge of business and government, irrespective of the person's occupation" [16, 215].

In a generalised form, white-collar crimes include crimes such as corrupt and other crimes, committed by public officials, as well as economic and professional crimes. This definition will be used for the purposes of this study. It should be noted that a more detailed analysis of the definition and types of white-collar crimes is not the aim of this article.

In modern criminal law, there is no doubt that white-collar crimes are real crimes for which criminal responsibility is applied. At the same time, there is a discussion on the theory of criminal law about what measure of such responsibility and punishment should be applied to white-collar criminals.

When solving this problem, it is necessary to consider the characteristics of white-collar criminality:

1) these crimes cause significant harm to public relations, which entails extremely negative consequences for society and the state as a whole;

2) usually, the society does not perceive these crimes as dangerous, treats them as loyal, which is explained by their non-violent nature and, as a rule, by the absence of harm to the property of individuals;

3) persons guilty of committing these crimes are characterised positively, do not pose a physical danger to society, which is significantly different from those committing ordinary crimes.

Further are discussed the characteristics of Ukrainian white-collar criminality.

Causing significant harm to public relations. As to the extent of the harm that leads to white-collar crimes in Ukraine, indicators such as corruption and the shadow economy can be concluded. It is known that these negative social phenomena arise from the commission of white-collar crimes, and, therefore, these phenomena are in a directly proportional relationship. 
Nataliya O. Gutorova. White-Collar Crime: Ukrainian Experience of Searching for Optimal Model of Criminal Liability

To determine the level of corruption in Ukraine, data of Corruption Perceptions Index 2017 from International Organisation Transparency International will be used. This index ranks 180 countries and territories by their perceived levels of public sector corruption according to experts and businesspeople, uses a scale of 0 to 100, where 0 is highly corrupt and 100 is very clean. In 2017, Ukraine ranked $130^{\text {th }}$ in this rating with 30 scores. To compare, Latvia has the $40^{\text {th }}$ rank ( 30 scores), Poland $-36^{\text {th }}$ (60 scores), Germany $-12^{\text {th }}$ (81 scores). From this rating, we can see that Ukraine is one of the most corrupted countries within the Europe and Central Asia group. In this group a higher index was observed only in Russia ( $135^{\text {th }}$ place), Kyrgyzstan $\left(135^{\text {th }}\right.$ place), Uzbekistan

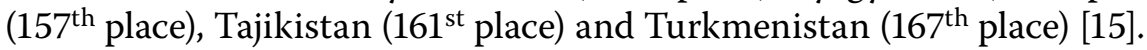

The next negative social phenomenon, derived from white-collar criminality, is the shadow economy. The study of the Association of Chartered Certified Accountants "Emerging from the shadows. The shadow economy to 2025", which was published in June 2017, the size of shadow economies of Ukraine in 2016 consisted of $45.96 \%$ of Gross Domestic Product (GDP). Among the 28 countries, the information on the shadow economy of which is presented to the study, the situation is worse only in Nigeria (48.37\% GDP) and Azerbaijan (67.04\% GDP). In Latvia, this indicator makes $24.17 \%$ GDP, in Poland $-23.68 \%$, in the USA $-7.78 \%$ [13].

A high level of corruption and shadow economy has an extremely negative impact on economic and social development of Ukraine. Despite the presence of significant natural resources, developed industry and agriculture, GDP per capita in Ukraine is extremely low. According to the information of the Word Bank, in 2016 Ukraine had GDP per capita $\$ 2,185.7$. To compare, GDP per capita in Latvia was $\$ 14,071.0$, Poland $\$ 12,414.1$, Germany - \$42,161.3, the USA - \$ 57,638.2 [14]. Due to non-payment of taxes and other illegal economic activities, the state does not have sufficient resources to fulfill social functions; a high level of corruption leads to a significant stratification of society, the bulk of which goes into the category of low-income people. This gives grounds for the conclusion that white-collar criminality causes significant damage to public relations.

Loyal attitude of society to white-collar criminals. For individuals who have committed corruption and economic crimes, society is much more loyal than towards traditional criminals, especially those who commit violent crimes and crimes against property of individuals.

Kamensky explains this situation as follows, "because of the corruption and the absence of perception of justice, fairness and accountability, both in politics and business, many white-collar crimes, such as smuggling, counterfeiting and tax evasion, are viewed as morally neutral, or even acceptable. It causes frustration and even hatred against the corrupt government engaged in self-dealing, and that does not operate for the benefit of the common folk is one of the major reasons for passive approval of such non-violent crimes with economic substance. This deviant ideology within economically oppressed society can be formulated this way: "The government cheats against you, so cheat it back". On the other hand, the vast majority of Ukrainian white-collar criminals 
also believe that cheating or embezzling is insignificant, at least with respect to moral barometers." $[8,344]$.

This attitude to the white-collar crimes contributes to its further spread. It has been observed that this affects the attitude of judges towards such persons. In many cases, the punishment imposed for the white-collar crimes is not strict; often such persons are generally exempted from serving their sentence.

Positive characteristics of white-collar criminals. When speaking about the characteristics of people committing white-collar crimes, it is necessary to take into account that they differ significantly from other criminals. To describe white-collar criminals, Sutherland used the words of Judge Woodward, which he had pronounced in 1933 upon imposing a sentence on the officials of $\mathrm{H}$. O. Stone and the company: "You are men of affairs, of experience, of refinement and culture, of excellent reputation and standing in the business and social world." [12, 8]. This characteristic is typical for this category of criminals, and, therefore, should be considered when establishing certain types of criminal penalties in the law and in applying the courts. If this is not done, then there is a high probability that the courts will be based only on a positive characterisation of a criminal's identity when assigning punishment. Such a situation will lead to the fact that a real criminal penalty will not be imposed.

Given the personality of white-collar criminals, it is not advisable to establish in the law a penalty in the form of a deprivation of liberty for crimes that are not serious. Such an assumption is based on the absence of physical danger for the society of such persons, as well as the large number of negative side effects of the punishment in the form of the deprivation of liberty.

The criminal law must solve a very difficult task, to create a system of criminal penalties for white-collar crimes that will be adequate to the damage caused by these crimes, capable of achieving the goals of preventing these crimes and, at the same time, adequate to the identity of white-collar criminals and society's attitude to their deeds.

Historical analysis of the criminal legislation of Ukraine and the practice of its application shows that over the past 50 years, the system of counteraction to these crimes has undergone significant changes several times. In many cases, the search for an optimal model of such counteraction was carried out by trial and error. At present, there is no reason to speak of an optimal solution to this problem.

Thus, during the period of Ukraine's membership in the USSR, the number of white-collar crimes that could be committed was extremely limited. This was due to the existence in the Soviet republics of the command and administrative system of management and the absence of a market economy.

At the same time, the Criminal Code of the Ukrainian Soviet Socialist Republic of 1960 established very strict penalties for such white-collar crimes as embezzlement, bribery and other crimes in the sphere of official activity. It was established in the criminal law that for such crimes long periods of deprivation of liberty with confiscation of property and deprivation of the right to hold certain positions or engage in certain activities 
should be applied. For example, Article 84 for the embezzlement of state or collective property by abuse of official position established a punishment from three to fifteen years of imprisonment with confiscation of property and with deprivation of the right to hold certain positions or engage in certain activities for up to five years; if such embezzlement was committed in especially large amounts, then in accordance with Article 86-1 the punishment was from ten to fifteen years of imprisonment with confiscation of property.

Article 168 established a punishment for a bribe from five to fifteen years of imprisonment with deprivation of the right to hold certain positions or engage in certain activities for a period of five years and confiscation of property. It was possible even to apply death penalty for some types of embezzlement and bribes. Courts in most cases did not have the opportunity to release the guilty from serving the sentence or to impose to him a milder punishment related to deprivation of liberty. Due to complete control of the state, as well as specifics of the economic system, the white-collar crimes were not widespread in the Soviet period. However, despite such serious criminal sanctions, the commission of these crimes was not a rarity.

After Ukraine had become independent in 1991, the liberalisation of economic system and development of a market economy began. At the same time, the number of white-collar crimes increased significantly, and new types of economic crimes appeared. So, along with corruption crimes and embezzlement, criminal responsibility was established for tax evasion, fraud with financial resources, fictitious entrepreneurship and other economic crimes.

In 2001, the new Criminal Code (CCU) was adopted in Ukraine. As in the Criminal Code of 1960, the main type of punishment for white-collar crime was deprivation of liberty; the fine was imposed as punishment only for a small number of economic crimes.

It should be noted that criminal legislation liberalised criminal liability for these crimes. Thus, terms of deprivation of liberty were significantly reduced, and Article 75 of the Criminal Code gave the opportunity to apply probation to persons who were sentenced to imprisonment for up to five years. However, in the criminal law the specificity of white-collar crime was not considered. In fact, a single approach to both white-collar and other criminals were used.

This situation very quickly changed the practice of applying criminal punishment for these crimes. Courts, like society as a whole, began to treat white-collar criminals very loyally. The fines imposed for these crimes were scanty, often significantly smaller than the damage caused by the crime.

In cases where the CCU only imposed a sentence of imprisonment for a particular white-collar crime (such us embezzlement, bribery, qualified types of tax evasion, fictitious entrepreneurship, etc.) the courts used probation almost in all cases on the basis of Article $75 \mathrm{CCU}$. This meant that if during a court-appointed probation period from one to three years such a person did not commit a new crime, did not systematically violate the public order, and did also perform the duties assigned to him by court, the punishment in the form of deprivation of liberty would not be enforced. Obligations that were imposed 
on the perpetrator were very simple and, as a rule, amounted to the following: 1) periodically appear for registration with the penitentiary offices; 2 ) inform these offices about the change in the place of residence. In fact, white-collar criminals remained unpunished.

For example, in the period from 2001 to 2011, for tax evasion in an especially large amount, Part 3 of Article $212 \mathrm{CCU}$ provided for punishment in the form of deprivation of liberty for five to ten years with confiscation of property and with the deprivation of the right to hold certain positions or engage in certain activities for up to three years. Analysis of the practice of courts of Ukraine for the period between 2008 and 2011 showed that more than $90 \%$ of the cases were sentenced to imprisonment for a period of five years, from serving of which the person was released with probation. Thus, the court had very broad opportunities for imposing punishment for these crimes; either to impose a penalty of imprisonment from five to ten years in real terms, or to release from serving a sentence with probation, which would mean actual impunity of the crime.

Impunity of white-collar crimes contributed to their widespread distribution, and also significantly increased corruption risks in this area.

On November 15, 2011, changes were introduced in CCU, which were aimed at changing the system of punishment of economic crimes. A penalty was imposed on the form with a fine for most of these crimes, instead of a non-alternative imprisonment. The size of the fine has increased significantly. It was also introduced as the rule that for more serious crimes the amount of the fine cannot be less than the amount of damage caused by the crime or the benefit obtained from the crime. For the first time in the Ukrainian legislation, it was provided for the replacement of an unpaid fine with imprisonment for a term from one to twelve years.

A significant shortcoming of these legislative changes was the fact that a high fine should be paid in a very short time, as the criminal law, as before, provides against the possibility of an installment payment of a fine not more than one year. Therefore, proceeding from the minimum in 2018 sums of taxes, evasion from payment of which is qualified in accordance with Part 3 of Art. 212 CCU, the minimum fine is UAH 4,405,000 (about EUR 136,377). If this amount is to be paid within a year, the monthly payment will be EUR 11,365. At the same time, the minimum wage in Ukraine at the beginning of 2018 was about EUR 115, almost 100 times lower than the monthly payment of the convict to a fine. If the fine is not paid on time, according to the criminal legislation (Article 53 of the $\mathrm{CCU}$ ), the convicted person will have to serve a sentence of imprisonment for ten years.

It can be assumed that the legislator thus tried to encourage white-collar criminals with hidden incomes (for example, assets of offshore companies, deposits on foreign currency accounts in foreign countries, property issued for other persons), to refund money to the state budget. However, analysis of judicial practice shows that this law is often used by people who have no income but have agreed to perform the functions of "fictitious directors". For such persons, there is no other way out of this situation, as serve a sentence to ten years of imprisonment in a year after the verdict of the court. 
The next innovation of the Ukrainian legislation in establishing the limits of criminal liability for white-collar crimes was a significant increase in repressiveness in relation to corruption offenses. By the law of February 12, 2015, changes were made to the CCU, which prohibited the use of incentive criminal law norms for corruption offenses.

Under this law, for example, if an investigator or a prosecutor received a bribe, then in accordance with Part 3 of Art. 368 of the CCU, they must be sentenced to imprisonment for a term of five to ten years with the deprivation of the right to hold certain positions or engage in certain activities for up to three years and with confiscation of property. In this case, court has no right to mitigate the punishment on the basis of Article $69 \mathrm{CCU}$, for example, to appoint a term of deprivation of liberty that is less than five years, or to apply a softer punishment. The court is deprived of the opportunity to apply probation on the basis of Article $75 \mathrm{CCU}$, or even to release from punishment a pregnant woman on the basis of Article 79 CCU.

The adoption of such harsh measures against white-collar criminals who committed corruption offenses, in my opinion, is currently justified. As already noted, the high level of corruption, which affects judicial system, requires strict and clear laws, leaving little room for judicial discretion. Simultaneously, such strict laws with respect to white-collar criminals are only permissible for a short time, as a "shock therapy".

Since the entry into force of this law has passed less than three years, analysis of judicial practice shows that the number of sentences to corrupt officials passed under this law fell sharply compared to the previous period. Yet, the time for consideration of criminal proceedings in courts increased. It can be concluded that the defense side, realising the inevitability of strict punishment, in every possible way delays trials in order to maximally delay the appointment of punishment in the form of over long periods of imprisonment.

Thus, the experience of Ukraine in the establishment and application of criminal responsibility for white-collar crimes can be defined as a "trial and error method". Lack of a well-thought-out, scientifically sound methodology for counteracting these crimes resulted in a drastic change in strategy in this matter. Initially, there were unreasonably cruel punishments for white-collar crimes in the Soviet period. Further, in the first 20 years of Ukraine's independence, the situation was characterised by almost total impunity due to extensive application of probation for these crimes. At present, there is an insufficiently thoughtful serious increase in criminal liability for corruption and some economic crimes.

As a result of this application of the criminal law, corruption and shadow economy have become widespread in Ukraine, which negatively affects economic and social development of the state.

The question remains what should be the optimal model of criminal ability for white-collar crimes. It should be noted that science of criminal law has not presented the indisputable and the only correct answer to this question. The Ukrainian criminalist Khavronuk states that over the course of its existence, earthlings have made more than three hundred scientific discoveries, which without a doubt can be considered a significant contribution; from writing and determining the duration of the year before 
the discovery of the boson to landing on Mars a 900-kilogramme rover with a full-scale research laboratory. Nevertheless, since the creation of the Bible until today lawyers have bothered to conclude that the punishment for a crime must be fair and adequate. The mystery remains how to make it real [5, 284-285].

It is obvious that bringing to criminal responsibility and imposing punishment on the person guilty of committing a crime in all cases, without exception, has to deal with negative consequences. It is not only a significant restriction of the rights and freedoms of the offender with possible negative consequences for his physical and mental health, but also negative consequences for his family and other persons connected with him, as well as the significant expenses of taxpayers' funds related to implementation of justice and execution of punishment.

This applies to all white-collar criminals. Moreover, taking into account their personal characteristics, the number of people whose rights and interests can be limited by the exposure of these negative side effects becomes significantly larger. To begin with, they are children, spouses, parents, and other people who receive substantial material support. In many cases, among white-collar criminals there are entrepreneurs who employ workers. Criminal liability and punishment in many cases lead to the cessation of the activity of such a business entity and, as a consequence, to the dismissal of workers.

Therefore, the construction of an optimal model of criminal responsibility for white-collar crimes should begin with a thorough justification for the need for criminalisation of the offense. Such criminalisation is not expedient in cases when white-collar offenses do not cause significant damage to society, and also if it is possible to effectively counteract them by civil-law or administrative measures.

Failure to respect the principle of proportionality in solving this problem leads to a violation of fair balance between the restriction of fundamental rights and significant advantages for society as a whole. This gives rise to such a negative phenomenon as overcriminalisation. Summarising the views expressed by American scientists on this issue, Kamensky concludes that "over-criminalisation may suggest that a phenomenon where the government establishes too many new crimes, punishes wrongdoing too severely, or generally imposes too much into the common citizens behavior" [8, 345].

This phenomenon is researched in criminal law as applied to criminalisation of offences in general $[7 ; 1]$ as well as to criminalisation of white-collar crimes $[4 ; 11]$.

Husak in his study Over-criminalisation. The limits of the Criminal Law defends a theory of the limits of penal sanction to combat the problem of over-criminalisation. This author is sure that

\footnotetext{
"it is important to recognise that this theory has an even broader application. A theory of criminalisation is needed to justify criminal laws we should retain, as well as to provide the criteria by which we should decide whether to enact even more penal legislation. Because I am more interested in retarding over criminalisation than in achieving these latter objectives; however, the theory I present consists in a number of constraints to limit the criminal sanction rather than a set of reasons to extend it" [7, V].
} 
Strader, based on the analysis of criminal cases of such white-collar crimes as financial fraud, concludes that the application of criminal law to such offenses is justified only in cases when civil and / or administrative remedies are insufficient and the harm is identifiable and substantial. In the financial fraud arena, the "harm is usually financial harm that is relatively simple to define, if not to quantify" [11, 50].

Such conclusions regarding the establishment of limits on criminalisation of whitecollar crime are justified. In general, a scientific study of the problems of criminalisation of white-collar offenses should be continued.

Another unsolved problem is punishment, which needs to be applied to white-collar criminals to achieve the goals of criminal liability. At the same time, it is necessary to consider internal inconsistency of these crimes: the enormous damage they cause to society and the positive attitude of society towards white-collar criminals, and also the positive characterisation of their personality. Finding a reasonable balance is very difficult.

Solution of this problem should be carried out by deciding the question of what goals of criminal punishment we want to achieve, and by what means we can do this. The main purpose of criminal punishment is to prevent commission of new crimes, which includes two components: special prevention or prevention of commission of new crimes by the convicted, and general prevention or prevention of commission of crime by other persons.

Achievement of special prevention in relation to white-collar criminals, as a rule, does not present a great deal of complexity. To do this, it is sufficient to apply punishment in the form of deprivation of the right to hold certain positions or engage in certain activities. If the occupation of a position becomes impossible, such a person will not be able to commit a new crime using this post. As for corruption crimes, the entry of the guilty person into the register of persons who have committed such crimes makes it impossible for the person to occupy a public position during his lifetime, which practically excludes commission of a repeated corruption offense.

It is much more difficult to achieve the second goal - to implement general prevention. In science of criminal law, it is proved that the attainment of this goal is possible in two ways: severity of criminal punishment and inevitability of its application. These two methods are in correlation dependence; the higher the level of inevitability of punishment, the less severe punishment can be and vice versa [6].

A serious negative side effect of conventional criminal penalties, in particular, deprivation of liberty, is the high cost of public funds for their implementation. Nobel Laureate-economist Becker in his work Crime and Punishment: The Economic Approach first applied the economic approach to crime problems. The author, based on his mathematical calculations, concludes that in counteracting crime, "optimal decisions are interpreted to mean decisions that minimise social loss in income from offenses" [3, 207].

It is interesting that Becker mathematically proved the correctness of the conclusions made back in 1764 by an outstanding Italian lawyer and economist di Beccaria in An Essay on Crimes and Punishments. More than 250 years ago, the scientist wrote, 


\begin{abstract}
"The certainty of a small punishment will make a stronger impression, than the fear of one more severe, if attended with the hopes of escaping; for it is the nature of mankind to be terrified at the approach of the smallest inevitable evil, whilst hope, the best gift of Heaven, hath the power of dispelling the apprehension of a greater; especially if supported by examples of impunity, which weakness or avarice too frequently afforded. ... That a punishment may produce the effect required, it is sufficient that the evil it occasions should exceed the good expected from the crime; including in the calculation the certainty of the punishment, and the privation of the expected advantage. All severity beyond this is superfluous, and therefore, tyrannical." [2, 94, 95]
\end{abstract}

Becker also concludes that the reduction in the number of crimes is significantly affected by the increase in the "probability that an offense is discovered and the offender apprehended and convicted". This is justified by the fact that "illegal activities "would not pay" (at the margin) in the sense that the real income received would be less than what could be received in fewer risky legal activities." If there is no high level of probability of criminal prosecution, then increasing the severity of punishments will not lead to the desired result, but at the same time significantly increase public spending on combating crime [3, 207-209].

This also applies to white-collar crime in a full measure. An effective model of counteraction to these crimes should include measures that can make their commission, on the one hand, the riskiest in terms of the probability of identifying and bringing to criminal responsibility, on the other - economically unprofitable.

As a rule, such punishments as deprivation of liberty and fine are imposed for white-collar crimes. As additional punishments can be confiscation of property and deprivation of the right to occupy certain positions or engage in certain activities.

Deprivation of liberty has long been a traditional form of punishment for criminal law. The ability of this type of punishment to perform a punitive function is obvious. In countries where there is no penalty in the form of the capital punishment, deprivation of liberty is the most severe form of punishment. Such punishment, as already noted, has significant negative side effects, and therefore, its application for white-collar crimes should be limited. The punishment should be imposed only for serious crimes with the aim of achieving the goal of general prevention, i.e. prevention of commission of crime by other persons. Such crimes include serious corruption crimes.

Thus, according to Paragraph 1 of Art. 19 of Criminal Law Convention Council of Europe on Corruption (1999) having regard to the serious nature of criminal offences established in accordance with this Convention, each Party shall provide, in respect of those criminal offences established in accordance with Articles 2 to 14, effective, proportionate and dissuasive sanctions and measures, including, when committed by natural persons, penalties involving deprivation of liberty which can give rise to extradition.

If white-collar crimes are not serious, then in such cases, the punishment in the form of deprivation of liberty should not be applied. Recommendation No. R (99) 
22 of the Committee of Ministers to Member States concerning prison overcrowding and prison population inflation (Adopted by the Committee of Ministers on September 30, 1999 at the $681^{\text {st }}$ meeting of the Ministers' Deputies) established that deprivation of liberty should be regarded as a sanction or measure of last resort and should, therefore, be provided for only, where the seriousness of the offence would make any other sanction or measure clearly inadequate. Member states should consider the possibility of decriminalising certain types of offence or reclassifying them so that they do not attract penalties entailing deprivation of liberty.

A real alternative to the deprivation of liberty is a restriction of liberty, for example, such as was introduced in Poland as a result of the reform of February 20, 2015. Describing this reform, Wiak writes,

\begin{abstract}
"After the changes implemented with the act of February 20, 2015, a penalty of restriction of liberty still consists in the obligation to perform unpaid supervised work for community purposes; however, its content may be supplemented with subsequent elements, such as the obligation to stay in the permanent place of residence or another designated place with the use of an electronic surveillance system, plus numerous obligations, which are probations in nature and, which have been imposed so far on a convict in the event of an imposed penalty of imprisonment with a conditional suspension of its execution. The period for which restriction of liberty may be imposed was extended to two years. A major decision of the legislator is also abolishment of the possibility of conditional suspension of this penalty." [17, 188-189]
\end{abstract}

This type of punishment in Poland has been applied for a brief period, so it is too early to draw conclusions about its effectiveness. However, it is obvious that it can be considered as an effective measure to combat white-collar crime. Advantages of this decision are that 1) this punishment is an alternative deprivation of liberty, which allows to minimise negative side effects for society and individuals; 2 ) it includes separate elements of probation, but it has a real punitive effect and does not lead to actual impunity for the offender.

Obviously, considering the personality characteristics of white-collar criminals in the aspect of their positioning as a higher class, the elite of society, the punishment in the form of supervised work (community service), without remuneration and for community purposes, for example, cleaning streets, can have a significant preventive effect. In combination with prohibition to change the permanent place of residence without permission, with the use of an electronic surveillance system, such measures will make it possible to achieve the goals of criminal punishment no less effectively than deprivation of liberty.

Another type of punishment, which is effective against white-collar criminals is a fine. This punishment can be used as the basic or as an additional one. In the latter case, it can be applied in addition to deprivation or restriction of liberty.

As noted by Becker, "fines have several advantages over other punishments: for example, they conserve resources, compensate society as well as punish offenders" [3, 208]. 
To ensure the effectiveness of the fine as a form of criminal punishment for whitecollar criminals, the following is necessary:

- a significant amount that will be a serious restriction of property rights of the offender, and will also depend on the damage or income caused by the crime as a result of such a crime;

- existence of a real possibility to pay the required penalty, which in many cases requires the possibility of an installment plan for a long period;

- replacement of the fine for imprisonment in case of evasion from payment.

Non-compliance with at least one of these conditions denies the possibility of this punishment in counteracting the white-collar crime.

Thus, the following system of criminal penalties can be proposed as an optimal model of sanctions for white-collar crime:

- basic punishment is a restriction of liberty (for certain serious crimes, there can be deprivation of liberty);

- additional punishments - fine and deprivation of the right to occupy certain positions or engage in certain activities;

- other measures of a criminally-legal nature - confiscation of proceeds from crimes or property obtained by criminal means.

The term of deprivation of liberty and the size of the fine must depend on the degree of public danger of crimes.

Of course, the problem of optimising criminal liability for white-collar crimes requires further scientific research. However, I strongly believe that this model will avoid, on the one hand, the groundless application of deprivation of liberty, on the other hand, impunity for these crimes due to the extensive application of probation.

\section{Conclusions}

White-collar crimes include crimes such as corruption and other crimes, committed by public officials, as well as economic and professional crimes. Characteristic features of this type of crime are: 1) it causes significant harm to public relations, which entails extremely negative consequences for society and the state as a whole; 2) usually, the society does not perceive these crimes as dangerous, treats them as loyal, which is explained by their non-violent nature and, as a rule, by the absence of harm to the property of individuals; 3) persons guilty of committing these crimes are characterised positively, do not pose a physical danger to the society, which is significantly different from those committing ordinary crimes.

To effectively combat white-collar crimes, the criminal law must solve a very difficult task: to create a system of criminal penalties for white-collar crimes that will be adequate to the damage caused by these crimes, capable of achieving the goals of preventing these crimes and, at the same time, adequate to the identity of white-collar criminals and the society's attitude to their deeds. 
The experience of Ukraine in the establishment and application of criminal liability for white-collar crimes can be defined as a "trial-and-error method". Lack of a wellthought-out, scientifically sound methodology for counteracting these crimes resulted in a drastic change in strategy in this matter. Initially, there were unreasonably cruel punishments for white-collar crimes in the Soviet period. Further, in the first 20 years of Ukraine's independence, the situation in this sphere was characterised by almost total impunity due to extensive application of probation for these crimes. At present, there is an insufficiently thoughtful serious increase in criminal liability for corruption and some economic crimes. As a result, corruption and shadow economy have become widespread in Ukraine, which negatively affects the economic and social development of the state.

The construction of an optimal model of criminal responsibility for white-collar crimes should begin with a thorough justification for the need for criminalisation of the offense. Such criminalisation is not expedient in cases when white-collar offenses do not cause significant damage to society, and also if it is possible to effectively counteract them by civil-law or administrative measures.

Another problem that needs to be solved, is punishment, which is advisable to be applied to white-collar criminals to achieve the goals of criminal liability. The main purpose of criminal punishment is to prevent commission of new crimes, which includes two components: special prevention or prevention of commission of new crimes by the convicted; general prevention, i.e. prevention of commission of crime by other persons. Special prevention of white-collar crimes, as a rule, is achieved through the use of punishment in the form of deprivation of the right to hold certain positions or engage in certain activities; this task is not very hard. The attainment of general prevention is possible in two ways: the severity of criminal punishment; inevitability of its application. These two methods are in correlation dependence - the higher the level of inevitability of punishment, the less severe punishment can be and vice versa.

Based on the studies of di Beccaria and Baker, it should be concluded that preference is given not too severe punishment, but to its inevitability. This approach will minimise the negative side effects of criminal punishment, as well as reduce the expenditure of public funds. An effective model of counteraction to white-collar crimes should include measures that can make their commission, on the one hand, the riskiest in terms of probability of identifying and bringing to criminal responsibility, on the other - economically unprofitable.

As a result, the following model of sanctions for white-collar crimes is proposed:

- basic punishment is restriction of liberty, which includes community service and prohibition to change the permanent place of residence without permission, with the use of an electronic surveillance system (for certain serious crimes there can be deprivation of liberty);

- additional punishments - fine and deprivation of the right to occupy certain positions or engage in certain activities; it is necessary to ensure the effectiveness 
of the fine as follows: 1) significant amount that will be a serious restriction of the property rights of the offender, and will also depend on the damage or income caused by the crime as a result of such a crime; 2) existence of a real possibility to pay the required penalty, which in many cases requires the possibility of an installment plan for a long period; 3) replacement of the fine for imprisonment in case of evasion from payment;

- other measures of a criminally-legal nature - confiscation of proceeds from crimes or property obtained by criminal means.

The term of deprivation of liberty and the size of the fine must depend on the degree of public danger of crimes.

\section{Balto apkaklīšu noziedzība: Ukrainas pieredze, meklējot kriminālatbildības optimālo modeli}

\section{Kopsavilkums}

Raksts veltìts problēmām, kas saistìtas ar kriminālatbildības optimizēšanu saistībā ar t. s. balto apkaklǐšu noziegumiem. Balstoties uz krimināltiesisko normu analīzi un to piemērošanas praksi Ukrainā pēdējo 25 gadu laikā, ir veikti pētījumi krimināltiesību un ekonomikas jomā, kā arī analizēta citu valstu pieredze kriminālatbildības piemērošanā par šādiem noziegumiem, lai izstrādātu optimālu sankciju modeli. Šì modeḷa mērḳis ir likvidēt noziedzību: novērst balto apkaklīšu darbības kriminalizāciju un efektīvi sodīt tās par noziegumiem.

Optimālā sankciju modelī attiecībā uz šiem noziegumiem būtu jāiekḷauj: 1) pamatsods - brīvības ierobežošana, kas ietver sabiedrisko darbu un aizliegumu mainìt pastāvīgo dzìvesvietu bez atḷaujas, izmantojot elektronisko uzraudzības sistēmu (par dažiem smagiem noziegumiem var piemērot brīvības atn̦emšanu); 2) papildu sodi - naudas sods un aizliegums ienemt noteiktu amatu vai veikt noteiktas darbības.

Savukārt naudas soda efektivitāti var panākt šādi: 1) piemērojot tik lielu naudas sodu, kas kḷūs par nopietnu pārkāpuma izdarītāja īpašuma tiesību ierobežojumu un būs atkarīgs no noziedzīgā nodarījuma radìto zaudējumu vai no tajā gūto ienākumu apjoma; 2) lai nodrošinātu reālu iespēju samaksāt nepieciešamo soda naudu, daudzos gadījumos nepieciešams noteikt ilgtermiṇa maksājuma plānu; 3) sodanauda jāaizstāj ar brīīibas atṇemšanu, ja notiek izvairīšanās no maksājuma; jāveic citi krimināltiesiska rakstura pasākumi - mantas un noziedzīgi iegūto līdzekḷu konfiskācija.

Brīvības atṇemšanas terminam un naudas soda lielumam jābūt atkarīgam no tā, cik liels kaitējums nozieguma dēl sabiedrībai radìts.

Atslēgvārdi: kriminālatbildība, sods, noziegumu novēršana, balto apkaklīšu noziegumi, naudas sods, brīvības ierobežojumi, brīvības atn̦emšana. 
Nataliya O. Gutorova. White-Collar Crime: Ukrainian Experience of Searching for Optimal Model of Criminal Liability

\section{References}

1. Baer, H. 2012. Choosing punishment. Boston University Law Review. 92, 577-641. Available from: http://www.antoniocasella.eu/nume/BAER_2012.pdf (accessed on 04.05.2018).

2. Beccaria, C. 1872. An Essay on Crimes and Punishments. By the Marquis Beccaria of Milan. With a Commentary by M. de Voltaire. A New Edition Corrected. Albany: W. C. Little \& Co. Available from: http://oll.libertyfund.org/titles/2193 (accessed on 04.05.2018).

3. Becker, G. S. 1968. Crime and Punishment: An Economic Approach. Journal of Political Economy. 76(2), 169-217.

4. Bennett, M., Levinson, J., Hioki, K. 2017. Judging Federal White-Collar Fraud Sentencing: An Empirical Study Revealing the Need for Further Reform. Iowa Law Review. 939-1000. Available from: https:/ilr.law.uiowa.edu/assets/Uploads/ILR-102-3-Bennett.pdf (accessed on 04.05.2018).

5. Dudorov, O. O., Khavroniuk, M. I. 2014. Kryminalne pravo: Navchalnyi posibnyk (Eng. Criminal Law: Textbook For Collegiate). K.: Vaite.

6. Gutorova, N. O. 2017. Sotsialna funktsiia kryminalnoho prava: problemy optymizatsii zasobiv yii realizatsii (Eng. Social function of criminal law: problems of optimisation of means of its realisation). Pravo Ukrainy. 2, 84-92.

7. Husak, D. 2008. Over-criminalisation: The Limits of the Criminal Law. In: Husak D. Overcriminalization: The Limits of the Criminal Law. Oxford: Oxford University Press. Available from: https://cryptome.org/2013/01/aaron-swartz/019532871X.pdf (accessed on 04.05.2018).

8. Kamensky, D. 2016. White-Collar Over-criminalisation in the United States: What Went Wrong? Visnyk Asotsiatsii kryminalnoho prava Ukrä̈n. 1(6), 339-362.

9. Melnychuk, T. V. 2015. Genezys teoryy belovorotnychkovoi prestupnosty v krymynolohycheskoi nauke (Eng. Genesis of the theory of white-collar crime in criminological science). Visnyk Zaporizkoho natsionalnoho universytetu. 2(I), 192-199.

10. Podgor, E., Dervan, L. 2016. White-Collar Crime: Still Hazy after All These Years. Georgia Law Review. 50(3), 709-767.

11. Strader, K. 2007. White-Collar Crime and Punishment: Reflections on Michael, Martha, and Milberg Weiss. George Mason Law Review. 45, 45-107. Available from: http://www.georgemasonlawreview.org/wp-content/uploads/2014/03/15-1_Strader.pdf (accessed on 04.05.2018).

12. Sutherland, E. 1940. White-Collar Criminality. American Sociological Review. 5(1), 1-12. Available from: http://www.asanet.org/sites/default/files/savvy/images/asa/docs/pdf/1939\%20 Presidential\%20Address\%20(Edwin\%20Sutherland).pdf (accessed on 04.05.2018).

13. The Association of Chartered Certified Accountants. Emerging from the shadows. The shadow economy to 2025. Available from: http:/www.accaglobal.com/content/dam/ACCA_Global/ Technical/Future/pi-shadow-economy.pdf (accessed on 04.05.2018).

14. The World Bank. GDP per capita (current US \$). Available from: https://data.worldbank.org/ indicator/NY.GDP.PCAP.CD (accessed on 04.05.2018).

15. Transparency International. Corruption Perceptions Index 2017. Available from: https://www. transparency.org/news/feature/corruption_perceptions_index_2017 (accessed on 04.05.2018).

16. U.S. Department of Justice. 1981. Dictionary of Criminal Justice Data Terminology. $2^{\text {nd }}$ ed., 215.

17. Wiak, K. 2016. Reform of a Penalty of Restriction of Liberty in Poland. Visnyk Asotsiatsï kryminalnoho prava Ukraïny. 1(6), 185-197. 


\title{
Autoru alfabētiskais rādītājs / Alphabetic List of Authors
}

\author{
Alfejeva, Jel̦ena 6, 8, 81 \\ Ërdmanis, Rihards 5, 7, 27 \\ Gutorova, Nataliya O. 6, 8, 100 \\ Kikors, Rolands 5, 7, 37 \\ Kokoszkiewicz, Artur 5, 7, 19 \\ Pashkov, Vitaliy M. 5, 7, 9 \\ Reisa, Linda 6, 8, 90 \\ Rinmane, Zane 5, 7, 50 \\ Vindele, Liene 5, 7, 66
}

